\title{
Out of Sight and Out of Line: The Need for Regulation of Law yers' Negotiations with Unrepresented Poor Persons
}

\author{
Russell Engler $\dagger$
}

In a variety of civil legal settings, negotiations between lawyers and unrepresented parties are common. Despite this fact, the ethical rules governing lawyers, as well as most ethics textbooks, fail to address such negotiations in any specific way. The ethical rules do, however, prohibit the giving of advice to unrepresented parties. Through an examination of the New York City Housing Court and other contexts where such negotiations are commonplace, the author concludes that lawyers frequently violate existing rules against giving advice to unrepresented parties. Because the unrepresented litigants often are poor, are people of color, and are women, these ethical violations fall most heavily on members of those groups. The author reviews several possible responses to lawyers' abuses of ethical rules, concluding that no single response will curtail the problem. He calls, therefore, for a strategy that combines enhanced enforcement of existing ethical rules, the passage of additional ethical rules concerning negotiations with unrepresented parties, increased supervision by courts, and expanded provision of counsel in civil actions.

\section{INTRODUCTION}

Negotiations between lawyers and unrepresented parties are common occurrences. Many litigants appear without counsel, a result not surprising given reports that over eighty percent of the legal needs of

Copyright $\odot 1997$ California Law Review, Inc.

$\dagger$ Associate Professor of Law and Director of Clinical Programs, New England School of Law. I am grateful, for their guidance and support, to Gary Bellow, Stephen Gillers, Josh Gray, Judi Greenberg, Jonathan Hyman, Ilene Klein, Tracy Miller, Barbara Oro, Russell Pearce, Raun Rasmussen, Deborah Rhode, Louise Trubek, and Mary Marsh Zulack. 
the poor and working poor currently are unmet. ${ }^{1}$ In some civil courts, as many as ninety percent of the defendants appear without counsel. ${ }^{2}$ Given that most civil cases settle, ${ }^{3}$ negotiations and communications between lawyers and their unrepresented adversaries occur frequently. Negotiations between lawyers and lay people also occur regularly in situations outside the scope of litigation. ${ }^{4}$

Despite the frequency of such encounters between lawyers and lay people, the ethical rules governing lawyers virtually ignore this scenario. Neither the Model Rules of Professional Conduct ("Model Rules"), nor the Model Code of Professional Responsibility ("Model Code"), contains a provision specifically regulating negotiations between lawyers and lay people. ${ }^{5}$ In the Model Rules, only a single rule speaks directly to a lawyer's dealings with an unrepresented adversary. ${ }^{6}$ Only a single

1. See, e.g., The Honorable Janet Reno, Address Delivered at the Celebration of the SeventyFifth Anniversary of Women at Fordham Law School, 63 FordHaM L. REV. 5,8 (1994) ("Ladies and gentlemen, at least eighty percent of the poor and the working poor in the United States do not have access to legal services.") (citing Talbot D'Alemberte, Racial Injustice and American Justice, A.B.A. J. Aug. 1992, at 58, 59); Louis S. Rulli, Pennsylvania Review, 1994-Foreword: Pennsylvania Legal Services at Risk, 68 TEMP. L. Rev. 541, 544 n.17 (1995) ("Comprehensive national and state studies have concluded that as much as $80 \%$ of the civil legal needs of the poor are unmet with current resources.") (citing American BaR Ass'N, Legal NeEds and Civil Justice: A Survey of Americans (1994); American Bar Ass'n, National Survey of the Civil Legal Needs of the Poor (1989); Report of the Pennsylvania Bar Ass'n Task Force for Legal Services to THE NEEDY (1990)).

A 1987 study of the legal needs of the poor in Massachusetts found that no more than $15 \%$ of the total legal needs of the poor were being met. MASSACHUSETtS Legal Assistance CoRP., Massachusetts Legal Services Plan for Action 3 (1987) [hereinafter MLAC Plan for ACTION]. "Between $85 \%$ and $92 \%$ of the low income people in Louisiana who had civil legal needs in 1991 were not represented by an attomey." William P. Quigley, The Unmet Civil Legal Needs of the Poor in Louisiana, 19 S.U. L. REv. 273, 273 (1992).

2. See, e.g., infra notes 121,163 and accompanying text.

3. "Settlement rates of about $90 \%$ are reinarkably constant in civil litigation, criminal cases, and family cases." Carrie Menkel-Meadow, Essay, For and Against Settlemtent: Uses and Abuses of the Mandatory Settlement Conference, 33 UCLA L. REv. 485, 488 n.19 (1985) (citing Marc Galanter, Reading the Landscape of Disputes: What We Know and Don't Know (and Think We Know) About Our Allegedly Contentious and Litigious Society, 31 UCLA L. Rev. 4 (1983)).

4. See, e.g., Robert M. Bastress \& Joseph D. Harbaugh, Interviewing, Counseling, AND NEGOTIATING 342 (1990) ("[M]ost clients present their lawyers with transactional or planning problems."); Richard L. Abel, Why Does the ABA Promulgate Ethical Rules?, 59 TEx. L. Rev. 639, 681 (1981) ("In the vast majority of transactions in every consuner sales or loan contract, for example, one party is unrepresented."); Rex R. Perschbacher, Regulating Lawyers' Negotiations, 27 ARIZ. L. REv. 75, 75-76 (1985) ("Negotiation ... is also important in a nonlitigation or transactional context such as in setting contract terms.") (footnotes omitted).

5. A number of commentators have written about the absence of meaningful ethical rules governing negotiations in general. See Geoffrey C. Hazard, Jr., The Lawyer's Obligation to Be Trustworthy When Dealing with Opposing Parties, 33 S.C. L. Rev. 181, 188 (1981); Gary Tobias Lowenthal, The Bar's Failure to Require Truthful Bargaining by Lawyers, 2 GEO. J. LEGAL ETHICS 411, 412-13 (1988); Perschbacher, supra note 4; Alvin B. Rubin, A Causeric on Lawyers' Ethics in Negotiation, 35 LA. L. REv. 577,579 (1975).

6. See Model Rules of Professional Conduct Rule 4.3 (1994). Rule 4.3 is one of the fifty-four Model Rules. While a number of other rules would apply to a lawyer facing an 
subsection of one disciplinary rule of the Model Code focuses exclusively on this situation. ${ }^{7}$ Thus, a reading of the rules of ethics suggests that cases pitting parties with lawyers against lay people are rare occurrences, or, at a minimum, the exception rather than the rule. ${ }^{8}$

Leading ethics and negotiation textbooks perpetuate the sense that cases involving unrepresented opponents are rare. For example, a sampling of ethics textbooks reveals that scant attention is paid to the lawyer's obligations when facing an unrepresented opponent in litigation. ${ }^{9}$ Textbooks for legal negotiation also fail to address ethical constraints on negotiation with an unrepresented litigant. ${ }^{10}$ Even articles and textbooks explicitly focusing on the ethics of negotiation either are silent on the issue of the ethics of negotiating with a lay person or provide only a passing reference."

unrepresented party opponent, for example Rule 3.4 (fairness to opposing party and counsel) and Rule 4.1 (transactions with persons other than clients), only Rule 4.3 speaks directly to this situation.

7. See Model Code of Professional Responsibility DR 7-104(A)(2) (1981). DR 7104(A)(2) is one subsection of the forty-one Disciplinary Rules in the Model Code. While a number of other rules would apply to the situation of the lawyer facing an unrepresented party opponent, for example DR 7-101 (zealous representation), DR 7-102 (representing a client within the bounds of the law), and DR 7-106 (regulating trial conduct), only DR 7-104(A)(2) is directly applicable.

8. See, e.g., Joel Dobris, Ethical Problems for Lawyers upon Trust Terminations: Conflicts of Interest, 38 U. MIAMI L. REv. 1, 46 (1983) ("The CPR [Code of Professional Responsibility] offers little guidance in resolving ethical questions when dealing with the unrepresented person."); Stephen Gillers, What We Talked About When We Talked About Ethics: A Critical View of the Model Rules, 46 OHı ST. L.J. 243, 264 (1985) ("[T] hese principles define a world in which each party is protected by counsel."); Rubin, supra note 5, at 579 ("The Code does not speak directly to the duty of a lawyer in dealing with laymen."). Referring to Canon 7 as "all the CPR has to offer," Dobris notes that "[n]either the Canon, nor the ECs [Ethical Canons] or DRs thereunder, offer useful guides to lawyer conduct." Dobris, supra, at 46.

9. See, e.g., Stephen Gillers, Regulation of Lawyers: Problems of Law and Ethics 92, 100 (4th ed. 1995) (containing only one passing reference to DR 7-104(A)(2) and a few references to Rule 4.3; topic is absent from Chapter VII, "Ethics in Advocacy," and Chapter X, "Negotiation and Transactional Matters"); GEOFFrey C. HAZARD, JR. ET AL., ThE LAW AND ETHICS OF LAWYERING 586-88, 1072-74 (2d ed. 1994) (containing two brief discussions of DR 7104(A)(2) and Rule 4.3); Thomas D. Morgan \& Ronald D. Rotunda, Professional RESPONSIBILITY 234, 261 (6th ed. 1995) (two brief references to DR 7-104(A)(2) and Rule 4.3; no mention of unrepresented adverse parties in Chapter VI, "Ethical Problems in Litigation"); DEBORAH L. Rhode \& David Luban, Legal Ethics 417, 772 (2d ed. 1995) (one brief mention of unrepresented parties and one reference to proposed Rule 4.3, but no reference to DR 7-104(A)(2)).

10. While issues of bargaining power and ethics in negotiation are topics that receive attention, the ethics of the negotiations between a lawyer and an unrepresented opponent do not. See, e.g., Bastress \& Harbaugh, supta note 4; Gary Bellow \& Bea Moulton, The lawyering Process (1978); Roger Fisher \& William Ury, Getting to Yes (Bruce Patton ed., 2d ed. 1991); Donald G. Gifford, Legal Negotiation (1989); LaRry L. Teply, Legal Negotiation in a NUTSHELl (1992).

11. See, e.g., BELlow \& Moulton, supra note 10, at 586-606 (no reference to negotiations against unrepresented parties in section entitled "The Ethical Dimension" in chapter on negotiation); TEPLY, supra note 10, at 183-93 (no reference to unrepresented parties, DR 7-104(A)(2), or Rule 4.3 in section entitled "Truth in Legal Negotiation"); Hazard, supra note 5, at 182 \& n.5; Lowenthal, supra note 5, at 421-22 \& n.56; Perschbacher, supra note 4, at 77-78 \& n.10; Rubin, supra note 5, at 579. 
Contrary to the impression created by the ethical rules and ethics texts, lawyer negotiations with unrepresented adversaries occur in vast numbers every day. Though the two rules that address directly lawyers' communications with unrepresented adversaries make clear that there are severe limitations on the permissible scope of negotiations with unrepresented parties, ${ }^{12}$ these limitations routinely go unheeded. ${ }^{13}$ Compounding the problem, the vast majority of these unrepresented parties already face significant power disadvantages in the legal system; unrepresented litigants often are poor, are women, and are people of color. ${ }^{14}$

This Article examines the ethical issues arising when lawyers negotiate with lay adversaries. Part I discusses the doctrine, context, and meaning of DR 7-104(A)(2) and Rule 4.3, the provisions of the Model Code and Model Rules governing a lawyer's communications with an unrepresented party opponent. As discussed more fully in Part I below, both provisions have been interpreted to prohibit lawyers from giving "advice" to unrepresented party opponents.

The prohibition of advice-giving significantly limits permissible attorney behavior in the context of negotiations. An attorney must refrain from giving legal advice, but must also refrain from suggesting a proposed course of action to the unrepresented adversary. The attorney must not mislead the unrepresented person, and must refrain from overreaching. The assessment as to whether an attorney's communications constitute impermissible advice must be made from the perspective of the unrepresented litigant. The inquiry depends on the characteristics and legal sophistication of the unrepresented party, as well as the setting in which the attorney's behavior or comment occurs.

Part $I I$ of this Article examines these restrictions in the context of New York City's Housing Courts, where most defendants go

12. Rule 4.3 prohibits a lawyer from stating or implying disinterest and requires the lawyer to make reasonable efforts to correct any misunderstandings held by the unrepresented party about the lawyer's role. DR 7-104(A)(2) prohibits a lawyer from giving advice to an adverse unrepresented party, other than the advice to seek counsel.

13. See infra Part 11.

14. Recent reports have identified widespread problems of gender, racial, and ethnic bias in the courts and in alternative dispute resolution settings. See infra notes 305-318 and accompanying text. Recent scholarship also has discussed how traditionally subordinated people are further subordinated and even silenced by the operation of the legal system. See, e.g., Barbara Bezdek, Silence in the Court: Participation and Subordination of Poor Tenants' Voices in Legal Process, 20 Hofstra L REv. 533-607 (1992) (discussing the failure of socially powerless people-mostly women, mostly black, almost all poor, and tenants-to articulate potentially meritorious claims in court); Erica L. Fox, Alone in the Hallway: Challenges to Effective Self-Representation in Negotiation, 1 HaRv. NEGOTIATION L. REV. 85 (1996) (analyzing the stlencing of unrepresented tenants during the process of negotiating with landlords' lawyers in court); Lucie E. White, Subordination, Rhetorical Survival Skills, and Sunday Shoes: Notes on the Hearing of Mrs. G., 38 BuFF. L. REv. 1 (1990) (discussing how the legal system, including legal aid lawyers, systematically undermines the power of already subordinated people, even as it grants them small victories). 
unrepresented. Drawing froin studies, articles, and other reports from court observers, the picture of New York City's Housing Courts that energes renders the conclusion that impermissible advice-giving to unrepresented adversaries occurs on a frequent and widespread basis. This unethical behavior is part of the regular fabric of the New York City Housing Courts.

Part II then turns to examples from other contexts to reveal that this problem is by no means limited to New York City's Housing Courts. Part II briefly examines housing cases outside of New York City, consumer cases, and cases arising in the family law context. An examination of these other contexts suggests that conditions inviting impermissible behavior are present in all "poor people's" courts across the country, and any place where lawyers regularly face large numbers of unrepresented parties.

Part III examines a range of responses to the problem of impermissible negotiation and advice-giving, including increased enforcement of the applicable ethical provisions, enactment of additional ethical rules governing lawyers' negotiations with unrepresented litigants, increased oversight by the courts, and the expansion of the provision of counsel, including a right to counsel, in civil settings in which lawyers routinely negotiate with unrepresented parties. An examination of these possible responses demonstrates that no single response will curtail the attorney misconduct. The widespread nature of the attorney misconduct, and the difficulties inherent in each response, render it unlikely that any one response in isolation will improve the current situation.

In his article Who Should Regulate Lawyers?, ${ }^{15}$ David Wilkins argues that a single enforcement structure will not be appropriate for all lawyers in all contexts. ${ }^{16}$ Rather, the profession will need to employ a combination of responses tailored to a particular context. ${ }^{17}$ Wilkins'

15. David B. Wilkins, Who Should Regulate Lawyers?, 105 HARv. L. Rev. 801 (1992). Professor Wilkins explores the "heated debate over who should have responsibility for regulating lawyers and how that authority should be exercised." Id. at 803 . Professor Wilkins "attempts to provide a framework for resolving these disputes." Id. For a series of articles and responses using Professor Wilkins' article as a backdrop, see 65 FoRDHAM L. Rev. 33-492 (1996). For a critique of Professor Wilkins' framework, see Ted Schneyer, Legal Process and the Regulation of Lawyers, 65 FORDHAM L. REv. 33, 53-58 (1996).

16. Wilkins, supra note 15 , at 887 ("This unitary vision, however, fails to account for the diversity in both the structure of the legal marketplace and society's expectations of the profession."). In his Afterword to the symposium issue based on his article, Professor Wilkins states that "the central premise underlying Who Should Regulate Lawyers, as well as most of the rest of my work, is that the traditional claim that a uniform set of ethical rules and enforcement practices governs all lawyers in all contexts is both descriptively false and normatively unattractive." David B. Wilkins, Afterword, How Should We Determine Who Should Regulate Lawyers?-Managing Conflict and Context in Professional Regulation, 65 FordhAM L. REv. 465, 482 (1996) (footnote omitted).

17. Wilkins, supra note 15 , at 804 . "[A]n optimal enforcement strategy would utilize some combination" of the regulatory approaches discussed by Professor Wilkins. Id. 
thesis is confirmed by the difficulties inherent in trying to select a single response to the problem of negotiations with unrepresented parties. Each of the possible solutions suggested here has serious flaws and limitations as a sole response to the ethical problem raised. The severity of the problem and the vulnerability of the unrepresented litigants require that the profession adopt a range of responses to begin to address it. By considering a range of responses as part of an overall enforcement strategy, this Article constitutes a case study of a possible regulatory strategy to address attorney misconduct in general.

The ethical problem identified in this Article raises an imposing challenge to the legal profession. Absent a right to counsel in civil cases, the difficulties facing unrepresented litigants in their encounters with lawyers are unlikely to be eliminated. ${ }^{18}$ That realistic assessment, however, provides no basis for the legal profession to refrain from taking meaningful steps to address the problem. Whether the profession will be willing to adopt a range of responses to the ethical problem will reveal much about the profession's concern for unrepresented litigants, as well as the profession's ability to regulate itself.

I

Limitations On Advice-Giving: The Ethical Rules

While the prohibition against advice-giving is widely recognized, what constitutes impermissible advice-giving is a source of confusion. The adoption of Rule 4.3 of the Model Rules, which dropped the specific language prohibiting advice-giving from the text of the rule to the commentary, was a response in part to the confusion surrounding the meaning of DR 7-104(A)(2). Decisions interpreting DR 7-104(A)(2) nonetheless shed light on the bounds of acceptable attorney behavior. Only a limited list of communications between an attorney and an unrepresented person is permissible under DR 7-104(A)(2). ${ }^{19}$ Moreover, despite the textual differences between Rule 4.3 and DR 7-104(A)(2), the prohibitions developed in the context of DR 7-104(A)(2) remain in effect even in jurisdictions that have adopted the Model Rules. ${ }^{20}$

To provide a framework for assessing the limitations on advicegiving, Part I.A discusses the text of, and background to, DR 7$104(A)(2)$, as well as a number of cases interpreting its prohibition of advice-giving. Part I.B discusses the relationship between DR 7104(A)(2) and Rule 4.3, its analogous provision in the Model Rules.

18. Even the adoption of a right to counsel in the civil context-an unlikely occurrence for the reasons discussed below-would not wholly resolve the problem, because many encounters between lawyers and lay people occur outside the context of litigation. See infra Part III.E.

19. See infra Part I.C.

20. See infra Part I.B. 
Part I.C analyzes the decisions in both contexts, providing an analytical framework for assessing whether attorney actions or statements constitute impermissible advice-giving. Part I.D reviews the limitations on advice-giving in the context of negotiations between a lawyer and an unrepresented adverse party.

\section{A. The Model Code: Disciplinary Rule 7-104(A)(2)}

Despite the widespread adoption of the ethical mles based on the American Bar Association's Model Rules of Professional Conduct, some states, including New York, remain governed by ethical rules derived from the ABA Code of Professional Responsibility. ${ }^{21}$ Disciplinary Rule 7-104 of the Code governs "Coinmunicating With One of Adverse Interest." DR 7-104(A)(2) provides that a lawyer, during the representation of his or her client, shall not "[g]ive advice to a person who is not represented by a lawyer, other than the advice to secure counsel, if the interests of such person are or have a reasonable possibility of being in conflict with the interests of his client."22

DR 7-104(A)(2) was hardly a novel concept when it was adopted. On the contrary, "[t]he restriction on a lawyer's ex parte communication with an unrepresented party opponent has a long history."23 Canon 9 of the old ABA's Canons of Professional Ethics prohibited communications with opposing parties in general. ${ }^{24}$ It further placed special emphasis on contacting unrepresented opposing parties: "It is incumbent upon the lawyer most particularly to avoid everything that may tend to mislead a party not represented by counsel, and he should not undertake to advise him as to the law."2s

Decisions interpreting Canon 9 provide an important backdrop to an analysis of DR 7-104(A)(2), both because DR 7-104(A)(2) succeeded Canon 9 and because courts interpreting DR 7-104(A)(2) have continued to rely on decisions under Canon 9. In one of its earliest formal opinions, arising in the divorce context, the ABA held that an attorney may not give an unrepresented adverse party "legal advice" in an attempt to secure the latter's consent to a course of action; the proper course for the attorney would be to tell the adverse

21. By 1995, over 40 states had adopted the ethical rules based on the ABA's Model Rules of Professional Conduct. David L. Yas, SJC to Adopt ABA Rules of Professional Conduct: Gives Time for Comment Before Finalized, MAss. L. WKLY., March 6, 1995, at A1.

22. MOdel CODE OF PROFESSIONAL RESPONSIBILITY DR 7-104(A)(2) (1981) (footnote omitted). DR 7-104(A)(1) prohibits communications with a represented client "unless he has the prior consent of the lawyer representing such other party or is authorized by law to do so." MODEL Code of Professional Responsibility DR 7-104(A)(1) (1981) (footnote omitted).

23. Attomey Q v. Mississippi State Bar, 587 So. 2d 228, 232 (Miss. 1991) (discussing history of Canon 9 of ABA's Canons of Professional Ethics and adoption of DR 7-104(A)(2)).

24. See id.

25. Id. (quoting Canons of Professional Ethics Canon 9 (1908)). 
party of the proposed action and recommend that he or she consult independent counsel. ${ }^{26}$ In another early case, involving workmen's compensation settlements, the ABA held that "[i]t is not improper for an attorney representing an employer to draw up settlement papers ... when the employee is not represented by counsel as long as the attorney does not advise or mislead the employee as to the law...."27 In the debt collection context, the ABA ruled that letters having the effect of telling recipients to "pay up or else" are improper even if they do not explicitly give advice..$^{28}$

With the adoption of the Code of Professional Responsibility, old Canon 9 was succeeded by DR 7-104 and Ethical Consideration 7-18. DR 7-104(A)(2) "carrie[d] forward the meaning and intent" of Canon 9 in limiting the lawyer's dealings with a party not represented by counsel. $^{29}$ EC 7-18 for the most part simply repeated the proscriptions against advice-giving that appeared in DR 7-104..$^{30}$

26. ABA Comm. on Professional Ethics and Grievances, Formal Op. 58 (1931). The decision was cited by the Second Circuit in W.T. Grant Co. v. Haines, 531 F.2d 671, 676 n.3 (2d Cir. 1976).

27. ABA Comm. on Professional Ethics and Grievances, Formal Op. 102 (1933). This opinion was cited with approval by the Massachusetts Supreme Judicial Court in Dolan v. Hickey, 431 N.E.2d 229, 231 (Mass. 1982). The decision also was cited by the Second Circuit in Haines, 531 F.2d at 676 n.3. The propriety of the practice at issue in light of the facts of the case, however, has been criticized in 2 Geoffrey C. Hazard, JR. \& W. William Hodes, The law Of Lawyering: a Handbook on the Model Rules of Professional Conduct $\S 4.3: 102$, at 747 (2d ed. 1996) ("For example, lawyers for insurance companies have been permitted to negotiate settlements with unrepresented tort victims and workers' compensation claimants, because it was held that they were not 'giving advice' about the legal significance of the settlement."). Such action "now seems to be clearly inappropriate behavior." Id.

28. The ABA ruled that a collection letter urging the recipient to settle at the level of the recipient's insurance coverage, so that the recipient would not be personally liable for any excess, constituted impermissible legal advice. ABA Comm. on Ethics and Professional Responsibility, Informal Op. 1034 (1968). The letter included the following sentences: "We have no way of finding out the amount of your insurance coverage. However, if the award exceeds the limits of your coverage, then under the law, you are personally liable for the excess out of your own pocket.

docs not want this to happen to you. It is the object of this letter to set your mind at ease and assure you that it need not happen." Id. The letter also included, in the words of the panel, "advice as to the course of conduct which the writer thinks that the defendant should pursue." The ABA relied on Informal Op. 734, which stated that it is improper to send collection letters that, without explicitly giving advice, have "the over-all effect upon lay recipients ... that they had better pay up "or else." ABA Comm. on Ethics and Professional Responsibility, Informal Op. 734 (1964).

29. ABA Comm. on Ethics and Professional Responsibility, Informal Op. 1140 (1970). The frequent use of Canon 9 decisions in interpreting DR 7-104(A)(2) supports the view that the prohibitions of Canon 9 remained in effect in the form of DR 7-104(A)(2). See, e.g., Haines, 531 F.2d at $676 ;$ Dolan, 431 N.E. $2 \mathrm{~d}$ at 231.

30. EC 7-18 provides in its entirety:

The legal system in its broadest sense functions best when persons in nced of legal advice or assistance are represented by their own counsel. For this reason a lawyer should not communicate on the subject matter of the representation of his client with a person he knows to be represented in the matter by a lawyer, unless pursuant to law or rule of court or unlcss he has the consent of the lawyer for that person. If one is not represented by counsel, a lawyer representing another may have to deal directly with the unrepresented 
While the prohibition of advice-giving has a long history, courts have struggled to identify what constitutes inpermissible "advice" under DR 7-104(A)(2). One difficulty is ascertaining whether the rule prohibits the giving of only legal advice or all kinds of advice. ${ }^{31}$ Another difficulty is determining whether certain words or actions constitute advice of any kind, regardless of whether it is legal or not. Three closely related $A B A$ decisions issued shortly after the adoption of the Model Code illustrate the difficulties in discerning between permissible and impermissible behavior. In the three cases, each of which arose in the context of a divorce proceeding, one spouse's attorney sought to obtain a waiver from the unrepresented spouse at the onset of litigation; the ABA found the waiver to be improper in the first two cases, but not in the third. ${ }^{32}$ Adding to the confusion, the $A B A$ subsequently withdrew the first two decisions, with little explanation..$^{33}$ Perhaps reflecting the

person; in such an instance, a lawyer should not undertake to give advice to the person who

is attempting to represent himself, except that he may advise him to obtain a lawyer.

Model Code of Professional Responsibility EC 7-18 (1981) (footnotes omitted).

EC 7-18 illuminates that the proscriptions appearing in DR 7-104 arise from the nature of the adversarial system. The structure of DR 7-104, which includes advice-giving both to represented party opponents (subsection $(A)(1)$ ) and unrepresented persons (subsection $(A)(2)$ ), reinforces the notion that an underlying assumption of the legal system is that both parties will be represented by counsel. The language of EC 7-18, that "a lawyer... may have to deal directly with the unrepresented person," would be inappropriate if the presence of the unrepresented party was a regular occurrence.

DR 7-104(A)(2) and EC 7-18 further assume that the decision to appear without counsel is a matter of choice, rather than one dictated by circumstances. The unrepresented person is one "who is attempting to represent himself," EC 7-18, rather than one forced to appear without counsel. The solution to the problem is that the unrepresented person should obtain a lawyer. No solution or remedy is suggested where obtaining a lawyer is unlikely or infeasible.

31. DR 7-104(A)(2) prohibits the giving of "advice" in general and without modification, whereas Canon 9 proscribed the giving of advice "as to the law." Compare Haines, 531 F.2d at 676 n. 3 (suggesting that the prohibition is for advice as to the law only) and Dolan, 431 N.E.2d at 231 (drafting documents and presenting them for execution, without more, does not amount to advice) with ABA Comm. on Ethics and Professional Responsibility, Informal Op. 1269 (1973) ("[a]s long as these documents are not accoinpanied by or coupled with the giving of any advice") (emphasis added).

32. The ABA found improper a broad waiver including a waiver of issuance of and service of summons, an agreement to consent to jurisdiction, and a waiver of other procedural rights, including notice to discovery. ABA Comm. on Ethics and Professional Responsibility, Informal Op. 1140 (1970).

Nor was it proper for an attorney "to submit or to mail ... an Appearance and Responsive Pleading to the other party in a domestic relations case for signature where that other party is not represented by an attomey." ABA Comm. on Ethics and Professional Responsibility, Informal Op. 1255 (1972).

No violation of DR 7-104(A)(2) would occur, however, where the unrepresented defendant was asked to sign only "a waiver of the issuance and service of summons and the entry of an appearance." ABA Comm. on Ethics and Professional Responsibility, Informal Op. 1269 (1973).

33. See ABA Comm. on Ethics and Professional Responsibility, Formal Op. 84-350 (1984) ("This opinion withdraws [Informal Ops. 1140 and 1255] which are inconsistent with both the Model Rules of Professional Conduct and the former Model Code of Professional Responsibility.... This opinion is based on the Model Rules of Professional Conduct of the American Bar Association."). 
analytical difficulties, some decisions simply assert, without explanation, that words or actions did not constitute advice. ${ }^{34}$

The Second Circuit's leading decision of W.T. Grant Co. $v$. Haines ${ }^{35}$ provides a deeper analysis of the issues, but fails to resolve the difficulties inherent in the application of DR 7-104(A)(2). ${ }^{36}$ In Haines, W.T. Grant's attorneys imterviewed employees, including Haines, on the same morning that outside counsel for Grant filed an action in federal court against the employees. ${ }^{37}$ Grant's counsel interrogated Haines for a total of five-and-one-half hours. The interrogation was tape-recorded. Hames stated that he had no objection to the tape-recording, and agreed voluntarily to take a polygraph test. He signed a statement in essence providing that he had not acted under duress and that he had been told of his rights to consult a lawyer. After the interrogation, Haines was told to report to Grant's personnel vice president, who informed Haines he was fired. ${ }^{38}$

The Second Circuit had great difficulty in determining whether the actions of Grant's counsel constituted impermissible advice within the meaning of DR 7-104(A)(2). "The question as to whether or not

The ABA Committee fails to explain either why the original informal decisions viewed the attorney's behavior as impermissible adviee-giving, or why the behavior now is considered proper. Presumably, the decision to withdraw the Informal Opinions followed discussions surrounding the adoption of the Model Rules.

34. See, e.g., In re Schiff, 542 S.W.2d 771 (Mo. 1976). In Schiff, the Missouri Supreme Court reviewed a disciplinary decision in which an attorney told an nnrepresented tenant that he would dismiss a proceeding for rent on a subsequent date if rent had been paid as the tenant alleged. The attorney instead took a default judgment for a subsequent month's rent cven though the tenant's allegations had been correct. Finding that the attorney had "knowingly allowed ... a layman, to rely upon his misrepresentations as to settlement," the Special Master ruled that the attorney's actions had violated various provisions related to deceit and general fitness to practice law, including DR 1102(A) generally and DR 1-102(A)(4), (5), and (6), in addition to DR 7-104(A)(2). Id. at 773. The court adopted most of the findings and conclusions of the Special Master. The court, however, reversed the finding that the attorney had violated DR 7-104(A)(2). Without elaborating, the Court held that "[a]lthough respondent told [the unrepresented tenant] that the case would be dismissed if it was determined that the rent had bcen paid, the conclusion that respondent violated DR 7-104(A)(2) is not warranted." Id. at 775.

Since the Court did not provide analysis, it is difficult to discern the precise nature of the "advice" that the attorney allegedly gave. Nor is it possible to discern why the Missouri Supreme Court found that the statements did not constitute advice, or whether the decision involved the issue of legal advice versus advice-giving in general.

35. 531 F.2d 671 (2d Cir. 1976).

36. Haines is the sole court decision mentioned in discussions of DIR 7-104(A)(2) in certain leading ethics textbooks. See, e.g., HAZARD ET AL., supra note 9, at 587-88; MORGAN \& RotUNDA, supra note 9, at 261. The decision also is discussed in 2 HAZARD \& HoDEs, supra note 27, $\$ 4.3: 105$, at 751-52.

37. The grounds for the action included violations of the Clayton Act, the Sherman Act, and various provisions of New York state law. The Second Circuit case arose on appeal of the lower court's decision denying the defendant-employces' motion to disqualify plaintiff's (Grant's) counsel. See Haines, 531 F.2d at 672-74.

38. See id. at 673-74. 
Haines's signing of those authorizations was the result of legal advice by opposing counsel within DR 7-104(A)(2) is not easily answered." ${ }^{39}$ The court quoted at length from the transcript regarding what was said by counsel and by Haines. ${ }^{40}$ "Whether this constitutes advice within the Rule and whether Haines acted on that advice or because of his own sense of obligation to Grant is a close question."41

The court agreed with the lower court that "the procedures adopted here were at least inappropriate and certainly not to be encouraged."42 The court noted that the interrogation occurred with the stated intent of giving Haines an opportunity to clear his name, yet outside counsel knew that Haines was about to be served, could not clear his name, and was about to be discharged. The lower court characterized the conduct of counsel as "soinewhat overbearing" and "lack[ing] the sensitivity which meinbers of the bar should show in dealing with laymen." 43

The court ultimately avoided determining whether the behavior constituted inpermissible advice within the meaning of DR 7104(A)(2). Since the DR 7-104 issue arose in the context of a motion to disqualify Grant's counsel, the court found that "the fact of professional misconduct is not necessarily determinative of the issue before us." "Rather than hold that Grant's counsel had in fact given impermissible advice, the Court "assume[d] a violation of DR 7-104(A)(2)" based on the facts, and then turned to the question of whether dismissal or disqualification was appropriate. ${ }^{45}$

The Mississippi Supreme Court similarly struggled to determine whether an attorney's statements constituted advice in Attorney $Q v$. Mississippi State Bar. ${ }^{46}$ In Attorney $Q$, an attorney appealed a disciplinary proceeding resulting in a private reprimand. In the course of a

39. Id. at 675 .

40. See id.

41. Id. at $675-76$.

42. Id. at 676 .

43. Id.

44. Id.

45. Id. at 676-77. Hazard \& Hodes contend that the lawyer's conduct in Haines violated both DR 7-104(A)(2) and Rule 4.3. 2 HAZARD \& HodEs, supra note 27, § 4.3:105, at 751-52; see also HAZARD ET AL., supra note 9, at 588 (suggesting that the lawyer gave "advice" by urging that cooperation might help alleviate Haines' legal problems).

For an article criticizing the Second Circuit for interpreting DR 7-104(A)(2) in a manner too protective of lawyers at the expense of unrepresented parties, see Kenneth L. Penegar, The Five Pillars of Professionalism, 49 U. PITT. L. REv. 307, 348-55 (1988).

46. 587 So. 2 d 228 (Miss. 1991). Attorney $Q$ involved an attorney's conduct in a personal injury action. The attorney represented a plaintiff who was an owner of a building claiming that the building had been damaged by defendant's vehicle when the vehicle left the road and struck the building. The attorney took statements from both the owner and driver of the vehicle, both of whom were without counsel. He subsequently asked them to come to the courthouse, where a sheriff delivered a summons to each. Id. at 229-30. 
dispute, Robinson, the defendant, had asked plaintiff's counsel, Attorney $Q$, whether she should contact her insurance company now that she had received a summons. The attorney responded, "No. Don't worry about it. Don't do anything." jected the attorney's claim that "don't worry about it" was not legal advice, but simply a "genial acclamation, such as 'keep a stiff upper lip." "48 The court reasoned that the issue was not what the attorney may have intended, but "what Robinson may reasonably have heard and understood." 49

The court's majority interpreted the attorney's statements "from the perspective of a reasonably intelligent non-lawyer in Robinson's position." 50 Viewing the statement from Robinson's perspective, the court held that "the only fair interpretation of what Attorney Q said to Robinson is that, once served with the summons, she did not need to worry about the matter and did not need to do anything about it."'s1

The context of the attorney's words divided the court as to whether the attorney impermissibly gave advice. Two justices dissented, concluding that "[t]he statement was not meant as legal advice and could not reasonably have been understood as legal advice." of the implications of the majority's holding, the dissent noted that "[o]ftentimes, opposing counsel will say to the other party, 'Don't be nervous, don't worry. We are going to only ask a few questions.' Are they to be punished?'s3

The Mississippi Supreme Court's decision is noteworthy because the court compared DR 7-104(A)(2) to the former Canon 9, which preceded DR 7-104(A)(2), and to Rule 4.3 of the Model Rules, which superseded DR 7-104(A)(2) in many jurisdictions. Since over forty

47. Id. at 230 (internal quotations omitted). Robinson did not contact her insurance company, no answer was filed, and the attorney obtained a default judgment against Robinson. Although the default judgment eventually was vacated and the matter tried on the merits, the disciplinary proceeding at issue ensued. Id. at 229-31.

48. Id. at 233 (internal quotations omitted).

49. Id.

50. Id. The court earlier had noted that "it is important that we remember" that the Complaint Tribunal had described Robinson as "a person of limited education and general business experience, a welder by trade, and of virtually no knowledge regarding matters of legal import." Id. at 230.

51. Id. at 233. The court added, "Attomey $\mathrm{Q}$ compounded his felony some forty days later when he had a default judgment entered against Robinson, although he has been formally charged with no disciplinary offense in this regard." Id.

52. Id. at 236.

53. Id. The dissent stated that the inajority was "being hoist with its own petard" in noting that the offending statement must be interpreted froin the perspective of a similarly situated, reasonably intelligent non-lawyer. Id. at 235. "Robinson had a GED diploma and performed reasonably demanding work. She was not illiterate, even though the majority uses the description welder in the pejorative sense." Robinson read the summons, "which clearly explains what to do and the consequences of failure to comply," and "has only herself to blame for failing to forward it to her insurance company." Id. 
states have replaced the Model Code with the ABA's Model Rules of Professional Conduct, it is important to examine the Model Rules and their interpretation before drawing conclusions as to the limits of permissible communications by attorneys to unrepresented party opponents.

\section{B. The Model Rules: Rule 4.3}

The Model Rules replaced DR 7-104(A)(2) with Rule 4.3, entitled "Dealing with Unrepresented Persons." 54 Rule 4.3 provides:

In dealing on behalf of a client with a person who is not represented by counsel, a lawyer shall not state or imply that the lawyer is disinterested. When the lawyer knows or reasonably should know that the unrepresented person misunderstands the lawyer's role in the inatter, the lawyer shall inake reasonable efforts to correct the misunderstanding. ${ }^{55}$

Rule 4.3 thus prohibits a lawyer froin stating or implying that the lawyer is disinterested. ${ }^{56}$ It fails, however, to include the prohibition of the giving of advice in the text of the rule. Instead, the language of DR 7$104(\mathrm{~A})(2)$ is relegated to the comment to Rule 4.3, where it appears in its entirety.

Hazard and Hodes write that "it was probably a mistake for the draftsinen to have deleted specific inention of 'giving advice."

54. See Model Rules of Professional Conduct Rule 4.3 (1983). Other rules also govern the interaction between an attomey and an unrepresented party opponent. The Model Rules include Rule 4.1 (Truthfulness in Statements to Others) and Rule 4.4 (Respect for Rights of Third Persons). Rule 4.3 nonetheless remains the closest analog to DR 7-104(A)(2).

55. Id.

56. Issues surrounding the interplay between Rule 4.2 and Rule 4.3 arise frequently where investigations take place as part of, or preceding, litigation. Rule 4.2 provides that "[i]n representing a client, a lawyer shall not communicate about the subject of the representation with a person the lawyer knows to be represented by another lawyer in the matter, unless the lawyer has the consent of the other lawyer or is authorized by law to do so." MODEL Rules of PROFEssional Conduct Rule 4.2 (1983). Where the potential witness might be represented by counsel, Rule 4.2 would govern. Where the potential witness is unrepresented, Rule 4.3 would apply. For a hotly contested case involving this scenario, see Monsanto Co. v. Aetna Cas. \& Sur. Co., 593 A.2d 1013 (Del. Super. C. 1990) (holding that an investigator's interactions with former employees of the opposing party are goverued by Model Rules 4.2 and 4.3). Similar issues arise in the context of government investigations in criminal and civil matters. See, e.g., United States v. Hammad, 846 F.2d 854 (2d Cir. 1988), corrected, 858 F.2d 834 (2d Cir. 1988); Bruce A. Green, Zealous Representation Bound: The Intersection of the Ethical Codes and the Criminal Law, 69 N.C. L. REv. 687, 690-704 (1991) (discussing the applicability of the Model Code, Model Rules, and criminal law to a defense attorney who must decide whether to inform a potential prosecution witness of his Fifth Amendment Privilege); Emest F. Lidge 1II, Government Civil Investigations and the Ethical Ban on Communicating with Represented Parties, 67 IND. LJ. 549 (1992) (examining the rule governing communications with a represented party in the context of civil investigations by the government).

57. 2 HAZARD \& Hodes, supra note 27, § 4.3:102, at 747-48. Professor Hazard served as reporter for the American Bar Association Speeial Commission on Evaluation of Professional 
conclude that the better formulation would have been both to adopt the language of Rule 4.3 and to retain the explicit prohibition of advicegiving in DR 7-104(A)(2). ${ }^{58}$

According to Hazard and Hodes, the Model Rules were designed to correct the problems that arose from the lack of clarity in the term "giving advice." ${ }^{\prime \prime}$ Rule 4.3 provided greater clarity by focusing on a possible misunderstanding about the lawyer's position, thus prohibiting misleading behavior short of advice-giving. On the other hand, under the Model Rules, a lawyer might be free to take unfair advantage of an unrepresented party once the lawyer's position has been revealed by the lawyer and understood by the unrepresented party. "As written, Rule 4.3 could be construed to mean that once the lawyer has disclosed her unfriendly status, she has fully met her obligation to the unrepresented party. In that view, she could then press on and cajole an unfavorable settlement or exact damaging admissions."

While Hazard and Hodes feared that Rule 4.3 of the Model Rules eliminated the prohibition of advice-giving, the Supreme Court of Mississippi rejected this view in Attorney $Q{ }^{61}$ Attorney $Q$ was privately reprimanded for giving advice to an unrepresented opponent in a civil action in violation DR 7-104(A)(2). During the pendency of his disciplinary proceeding and appeals, Mississippi adopted the Model Rules, replacing DR 7-104(A)(2) with the language of Rule 4.3. Ainong the arguments Attorney $Q$ raised on appeal was that Rule 4.3 was more "liberal" than DR 7-104(A)(2), and thus, presumably, that the giving of advice was no longer prohibited. ${ }^{62}$

The Mississippi Supreme Court "perceive[d] no change of substance in the current rules." ${ }^{33}$ The court reviewed the long history of the "restriction on a lawyer's ex parte communication with an

Standards, the "Kutak Commission," which recommended what eventually became the Model Rules of Professional Conduct.

Hazard and Hodes observe that, for the most part, the language of DR 7-104(A)(2) solved the underlying problem of an attorney's dealings with an unrepresented adversary. The rule "prevented a lawyer from influencing (advising) a lay person to do something or to waive a right that would be in the interest of the lawyer's client, but not in the interest of the unrepresented person." Id. § 4.3:102, at 747 .

58. "Although the Comment to Rule 4.3 incorporates the old language of DR 7-104, and bars a lawyer from giving 'advice' to an unrepresented person, the black letter rule would have been stronger if it too had contained such language...." Id. $\$ 4.3: 102$, at 748 .

59. Id. $\$ 4.3: 102$, at 747-48. As Hazard and Hodes note, under DR 7-104(A)(2) it remained uncertain whether the prohibition against giving advice was limited to giving legal advice. If so, a lawyer interviewing a prospective defendant in a civil suit might be unfairly laying traps for his future opponent, without actually "giving advice" in the usual meaning of the term.

60. Id. $\$ 4.3: 102$, at 748 .

61. Attorney Q v. Mississippi State Bar, 587 So. 2d 228, 232 (Miss. 1991).

62. Id.

63. Id. 
unrepresented party opponent."64 The court quoted extensively from the Comment to Rule 4.3, which included language similar to DR 7104(A)(2). Relying on the Comment to Rule 4.3 and the history of its predecessor rules, the court concluded that "the only change is one of form." $"$ s5

Other jurisdictions are likely to agree with Mississippi that behavior that would have constituted a clear violation of DR 7-104(A)(2) is improper under Rule 4.3 of the Model Rules. Colorado, the District of Columbia, Louisiana, and Pennsylvania each explicitly retained the language of DR 7-104(A)(2) in the text of Rule 4.3. ${ }^{66}$ One Florida appellate court simply assumed that the prohibition contained in DR 7$104(A)(2)$ was carried over into Rule 4.3.67

It is unlikely that a state would conclude that its decision to adopt the Model Rules amounted to a license for attorneys to give advice to unrepresented adversaries. Instead, the same analysis should apply regardless of whether a particular jurisdiction has adopted the Model Code or Model Rules. It is therefore imperative to develop from the decisions of courts and ethics panels the circumstances and contexts in which attorney behavior will be recognized as advice-giving and thus impermissible. Absent some sense of what is permissible and impermissible behavior, the question of whether particular behavior is appropriate is left to ad hoc decisions. Attorneys, unrepresented litigants, judges, disciplinary committees, and the public in general are left with no yardstick for measuring existing behavior to determine when attorneys have "crossed the line."

\section{Understanding the Limits and Contexts of Advice-Giving}

A series of themes regarding permissible attorney behavior toward an unrepresented adversary can be culled from the decisions interpreting DR 7-104(A)(2) and Rule 4.3. The themes emerge despite the fact that the decisions were rendered by different tribunals, considering different facts arising in different contexts. These differences, however, raise a threshold question of whether it is appropriate to treat the governing cases and ethics opinions as a unified body of law. Siguificantly, the courts themselves treat these decisions as a unified body of law, regularly crossing the boundaries of jurisdiction and

64. Id.

65. Id. at 233.

66. See Stephen Gillers \& Roy D. Simon, Jr., Regulation of Lawyers: Statutes and STANDARDS 277 (1996). Massachusetts' proposed Rule 4.3 also retains the language of DR 7 . 104(A)(2). See Proposed Rules of Professional Conduct, Mass. L. WKLY., June 24, 1996, at B1.

67. Tenneboe v. Tenneboe, 558 So. $2 \mathrm{~d} 470,474$ n.6 (Fla. Dist. Ct. App. 1990) (relying on the Comment to Rule 4.3, without mentioning DR 7-104(A)(2)). 
context in rendering their decisions. ${ }^{68}$ It is appropriate to do the same in an effort to identify guiding analytical themes.

Decisions that approve certain behavior provide initial clues. First, drafting legal documents and presenting them for signature, without more, does not amount to advice. ${ }^{69}$ Second, a statement of the action the lawyer's client proposes to take does not amount to impermissible "advice." To Third, a statement advising an unrepresented person to obtain independent counsel is not only permissible, but may become mandatory once communication is inevitable." Fourth, statements necessary to clarify that the lawyer is not disinterested, or to correct a misunderstanding as to whether the lawyer is disinterested, are permissible and may also be mandatory. ${ }^{72}$

Whether communications with an unrepresented person of adverse interest must be limited to the four categories above, or whether other forms of communication are permissible, requires an assessment of behavior found to be improper. That assessment reveals that many communications between an attorney and an unrepresented person with an adverse interest constitute impermissible advice.

68. For example, in Attorney $Q$, which arose in the disciplinary context, the Mississippi Supreme Court relied on ABA Informal Opinion 1140. Attomey Q v. Mississippi State Bar, 587 So. 2d 228, 232 (Miss. 1991). The Second Cireuit, in Haines, considering an appeal of a motion to disqualify counsel, relied on ABA Informal Opinions 1140,1269, and 1034, ABA Formal Opinions 102 and 58, and the New York State Bar Association Committee on Professional Ethics Opinion 358. W.T. Grant Co. v. Haines, 531 F.2d 671, 676 n.3 (2d Cir. 1976). In Dolan, the Massachusetts Supreme Judicial Court relied on ABA Formal Opinion 102 and Informal Opinion 1269 in resolving a dispute over a deficiency after foreclosure of a second mortgage. Dolan v. Hickey, 431 N.E.2d 229, 231 (Mass. 1982).

69. See, e.g., Dolan, 431 N.E.2d at 231 ("The acts of drafting documents and presenting them for execution, without more, do not amount to 'advice,' and are proper as long as the attorney does not engage in misrepresentation or overreaching."). Dolan arose in the context of a real estate closing. The case involved the efforts of the defendant-mortgagors to defend against a mortgage deficiency action. The Hickeys sought to avoid liability on the grounds of fraud, misrepresentation, and illegality. In particular, the Hickeys contended that the bank's attorney was acting as a fiduciary and had failed to disclose his interest and further had failed to advise the Hickeys to seek independent counsel. The court concluded that none of the facts suggested that an attorney-client relationship, or other confidential relationship, had arisen prior to the closing. The court further held that the attorney did not "give advice" to unrepresented parties with interests adverse to those of a client, "as prohibited by DR 7-104(A)(2)." Id.

Even this conduct, however, should be limited where the documents presented yicld an unconscionable result. See infra Part IIl.B.

70. See Haines, 531 F.2d at 676 n.3 (citing ABA Comm. on Professional Ethics and Grievances, Formal Op. 58 (1931)).

71. See DR 7-104(A)(2). But see ABA Comm. on Ethics and Professional Responsibility, Informal Op. 1194 (1971) (providing that while a lawyer may advise an unrepresented opponent to obtain counsel and of the availability of lawyer referral or reference service, "[t]]o permit more than this by recommending, for example, a particular lawyer would raise questions of the bona fides of the lawyer's adverse position").

72. See Model Rules of Professional Conduct Rule 4.3 (1983). 
First, communications that include misrepresentation and overreaching are impermissible. ${ }^{73}$ An attorney may not misrepresent the law, the facts, or the identity and interests of the attorney. ${ }^{74}$ Concerns about attorney overreaching may explain court and ethics decisions regarding appropriate behavior in obtaining signed waivers or authorizations. ${ }^{75}$ Defining what constitutes misrepresentation or overreaching, however, may be as subjective as defining what constitutes advice.

In addition to misrepresentation and overreaching, the decisional authorities uniformly prohibit attorneys from giving legal advice to an unrepresented opponent. ${ }^{76}$ Yet the term "legal advice" is not defined

73. See Dolan, 431 N.E.2d at 231 ("The acts of drafting documents and presenting them for execution, without more, do not amount to 'advice,' and are proper as long as the attorney does not engage in misrepresentation or overreaching.") (emphasis added); ABA Comm. on Professional Ethics and Grievances, Formal Op. 102 (1933) ("lt is not improper... to draw up settlement papers... as long as the attorney does not advise or mislead ... as to the law ....") (emphasis added).

Where misrepresentations are involved, provisions beyond DR 7-104(A)(2) or Rule 4.3 may well be implicated. See, e.g., In re Schiff, 542 S.W.2d 771, 773 (Mo. 1976) (behavior alleged to be misleading giving rise to charges not only under DR 7-104(A)(2), but also under DR 1-102(A) generally and DR 1-102(A)(4),(5), and (6)).

74. ABA Formal Opinion 102 talks initially in terms of misleading as to the law, and later recognizes as improper misleading behavior concerning the law or facts. See ABA Comm. on Professional Ethics and Grievances, Formal Op. 102 (1933) ("[T]he attorney in drafting the settlement papers... particularly must avoid misleading the servant concerning the law or the facts.") (emphasis added)). Dolan discusses misrepresentation in general. See 431 N.E.2d at 230-31. Rule 4.3 of the Model Rules refers to misunderstandings as to the lawyer's role in the matter and requires clarification where a misunderstanding has occurred.

In addition to Rule 4.3 and DR 7-104(A)(2), both Rule 4.1 and DR 7-102(A)(5) prohibit a lawyer from making various misrepresentations with regard to the law or facts. Rule 4.1 of the Model Rules limits the making of a false statement of "material" fact or law to third persons, while DR 7$102(A)(5)$ of the Model Code prohibits a lawyer from "knowingly" making a false statement of law or fact.

See also Sainsbury v. Pennsylvania Greyhound Lines, 183 F.2d 548, 550-51 (4th Cir. 1950) ("The rule is also well established that when a lawyer makes a misrepresentation of law to a layman relief may be afforded, even though the layman knows the lawyer represents an antagonistic interest. Any other rule would be unconscionable."); In re Skinner, 214 N.W. 652, 653 (Minn. 1927) ("Misconduct or deception towards others than clients and in matters other than legal controversies or lawsuits may be such as to require the removal of an attorney from his office."); Jeska v. Mulhall, 693 P.2d 1335, 1338 (Or. Ct. App. 1985) (declaring misrepresentation of fact by lawyer to lay person actionable).

75. Thus, for example, in Haines, the Second Circuit may have chosen to assume a violation of DR $7-104(A)(2)$ rather than actually to find one because the behavior seemed to involve overreaching more clearly than it did advice-giving. The court, without explicitly finding that improper advice-giving had occurred, "agree[d] that the procedures adopted here were at least inappropriate and certainly not to be encouraged." W.T. Grant Co. v. Haines, 531 F.2d 671, 676 (2d Cir. 1976).

76. See, e.g., Haines, 531 F.2d at 676 n.3; ABA Comm. on Professional Ethics and Grievances, Formal Op. 102 (1933); ABA Comm. on Professional Ethics and Grievances, Formal Op. 58 (1931). Even in the disagreement between the majority and the dissent in Attorney $Q$, the dissent never questioned the proposition that advice-giving was prohibited under either DR 7-104(A)(2) or Rule 4.3; the dispute was a factual one regarding whether the attorney's words constituted advice. Attorney Q v. Mississippi State Bar, 587 So. 2d 228, 234-36 (Miss. 1991) (McRae, J., dissenting); see also People v. Davis, 911 P.2d 45, 46-47 (Colo. 1996) (holding that attorney's advice to unrepresented 
by DR 7-104(A)(2), Rule 4.3, or the cases interpreting those provisions. What constitutes "legal advice" also is an important inquiry in cases involving alleged attorney malpractice, ${ }^{n}$ efforts to obtain documents claimed to be protected by the attorney-client privilege, ${ }^{78}$ and the unauthorized practice of law. ${ }^{79}$ Definitions used in these other contexts therefore are a useful starting point for understanding the prohibition of giving legal advice to an unrepresented adversary.

"Legal advice is often defined as giving an opinion as to the law applicable to the subject matter." ${ }^{\prime 80}$ For the purpose of recognizing impermissible statements or communications to unrepresented persons, this definition of legal advice is mstructive. Since a lawyer is prohibited from giving legal advice to an unrepresented adverse party, at a minimum, a lawyer must not give an opinion as to the law applicable to the subject matter.

The prohibition of advice-giving, however, is not limited to legal advice as defined above. The text of DR 7-104(A)(2) prohibits not only legal advice, but advice in general, without qualifying language. ${ }^{81}$

individuals that they did not need a lawyer to review two movie production agreements violated DR 7-104(A)(2)).

77. See, e.g., Franko v. Mitchell, 762 P.2d 1345, 1351 (Ariz. Ct. App. 1988) (holding that an attorney is held to the same standard of care in proferring legal advice whether or not such advice is gratuitous); Togstad v. Vesely, Otto, Miller \& Keefe, 291 N.W.2d 686, 693 (Minn. 1980) (holding that plaintiff was injured when defendant attorney advised her that she had no medical malpractice claim).

78. See, e.g., Crane v. Crane, 614 A.2d 935, 940-41 (D.C. 1992) (Terry, J., concurring).

79. See, e.g., In re Opinion of the Justices, 194 N.E. 313, 317-18 (Mass. 1935); Dayton Bar Ass'n v. Lender's Serv., Inc., 532 N.E.2d 120, 122-23 (Ohio 1988). The giving of legal advice is central to the determination of whether a non-attorney has engaged in the unauthorized practice of law.

80. Franko, 762 P.2d at 1360 (Grant, J., concurring in part and dissenting in part) (citing Togstad, 291 N.W.2d at 692-93).

81. While the Second Circuit suggested in Haines that the prohibition of advice-giving referred to legal advice, it failed to consider the change in text from Canon 9 to DR 7-104(A)(2); moreover, the court rehed primarily on the old $\mathrm{ABA}$ decisions under Canon 9, with its different text. Haines, 531 F.2d at 676 n.3.

One source of the confusion was the ABA's declaration that the effect of former Canon 9 and DR 7-104(A)(2) "appears to be substantially the same." ABA Comm. on Ethics and Professional Responsibility, Informal Op. 1140 (1970). Informal Opinion 1140 declared that DR 7-104(A)(2) simply carried forward the meaning and intent of the old Canon 9. Id. The facts of Informal Opinion 1140 , however, did not call into question the distinctions between "advice" and "legal advice" or between an unrepresented "party" or "person." Id. As a result, Informal Opinion 1140 should not be read as asserting that DR 7-104(A)(2) did not broaden the prohibition embodied in Canon 9. Rather, it should be read as asserting that the meaning of Canon 9 is included in the meaning of DR 7104(A)(2). Informal Opinion 1140, moreover, was later withdrawn in a Formal Opinion. See ABA Comm. on Ethics and Professional Responsibility, Formal Op. 84-350 (1984).

The new Disciplinary Rule in the Model Code differed from Canon 9 in two other respects. First, DR 7-104(A)(2) omitted the proscription against "misleading" an unrepresented person with an adverse interest. As discussed more fully above, however, the misleading of an unrepresented party opponent not only remains prohibited under DR 7-104(A)(2), but likely would violate other provisions of the Model Code or Model Rules as well. See supra Part I.B. 
The ABA has held that it is impermissible for one party's attorney to advise an unrepresented party of the course of conduct the attorney thinks the latter should pursue. ${ }^{82}$ The ABA's decision was cited with approval by the Second Circuit in Haines. ${ }^{83}$

The ABA's decision prohibiting an attorney from advising the unrepresented party as to a proposed course of conduct the unrepresented party should take is the proper one. In advising their own clients, lawyers do not merely give their opinions as to the application of the law to the facts of the client's case. They also routinely advise their clients as to what the clients should do under the circumstances, and clients consult lawyers expecting to receive such advice. ${ }^{84}$

Prohibiting a lawyer from giving an opinion as to what the unrepresented adversary should do therefore goes to the heart of DR 7104(A)(2). The fear that an opposing lawyer might use undue influence over the unrepresented party reflects the possibility that the unrepresented party may take action as a result of the influence. Faced with a legal problem, the unrepresented party may be influenced as much by the lawyer's opinion or proposal as to what the unrepresented party should do as by the lawyer's opinion as to how the law applies to the matter at hand. Prohibiting a lawyer from proposing a course of conduct for the unrepresented adversary to take therefore goes to the heart of DR 7-104(A)(2), and yet this type of advice is not necessarily an opinion as to the law applicable to the subject matter.

Second, DR 7-104(A)(2) broadened the proscription by replacing "party" with "person." Lawyers therefore were prohibited from giving advice not simply to unrepresented party opponents, but to all unrepresented persons whose interests "are or have reasonable possibility of being in conflict" with the interests of the lawyer's client. MODEL CODE OF PROFESSIONAL RESPONSIBILITY DR 7-104(A)(2) (1981). See Attorney $Q, 587$ So. 2d at 232. The expansion of DR 7-104(A)(2) to include unrepresented persons other than a party opponent is beyond the scope of this Article.

The notes to the early drafts of DR 7-104(A)(2) fail to shed light on these issues, citing Canon 9 and Formal Opinions 58 and 102, without explanation. See MODEL CODE OF PROFEssionaL Responsibility Canon 7 nn.71-72 (Preliminary Draft 1969).

82. See ABA Comm. on Ethics and Professional Responsibility, Informal Op. 1034 (1968); ABA Comm. on Professional Ethics and Grievances, Formal Op. 58 (1931).

83. The Haines court cited for the same proposition both ABA Informal Opinion 1034 and a New York State Bar Association opinion. Haines, 531 F.2d at 676 n.3 (citing N.Y. State Bar Ass'n Comm. on Professional Ethics, Opinion 358 (1974) (finding that it is impropor for the attomey of a personal-injury plaintiff to send a copy of a letter to an unrepresented proposed defendant advising that the failure to settle within the latter's insurance policy limits would be considered bad faith, thus exposing defendant to judgment in excess of the policy limits, behavior that amounted to the improper giving of "legal advice" within the meaning of DR 7-104(A)(2))).

84. A leading textbook makes clear that advice-giving in the context of counseling by a lawyer of the client is by no means limited simply to giving an opirion as to the applicable law to the subject matter. See, e.g., David A. Binder et Al., Lawyers As Counselors: A Client-Centered APPROACH 260 (1991) ("Advice consists of your opinion. You may advise a client both about what consequences (legal and/or nonlegal) ure likely to flow from alternative courses of action or about which alternative a client should adopt."). 
Accordingly, the debate surrounding whether the rule prohibits merely "legal advice" or advice in general is a red herring. The critical inquiry is whether a statement has the effect of proposing a course of action, rather than whether it constitutes legal advice. Giving legal advice to an unrepresented adverse party is inappropriate precisely because it may have the effect of influencing the party's course of action. The definition of advice therefore must be crafted in terms of the need to protect the unrepresented party from the lawyer's influence. The prohibition of advice-giving must include prohibiting a lawyer from both giving an opinion or counsel and proposing or recommending a course of action..$^{85}$

For example, if a landlord's attorney advises an unrepresented tenant that there is other housing that the tenant could find in a given city, that advice may seem to be advice regarding the real estate market for rental housing rather than legal advice. However, if the effect of the comment is to persuade a tenant to agree in a legal proceeding to move out of her apartment, the effect of the comment is the same as if the lawyer had said, "You should take this deal in which you move out of your apartment." The attorney is impermissibly advising the unrepresented adverse party as to a proposed course of action, without rendering an opinion as to the law applicable to the facts at issue.

Similarly, if an attorney advises an unrepresented adversary that there are ample jobs available for a person with her skills, this seems to be advice about the job market rather than about the law. In the context of a divorce proceeding, where the attorney is trying to persuade the wife to drop a claim to remain on her husband's health care plan, however, the statement has a different meaning: it is advice to the wife that she can easily obtain health care on her own because jobs are plentiful. This may be the same as saying, "You should take this deal without requiring health care coverage." Again, though not explicitly giving an opinion as to the law governing the subject matter at issue, the attorney is proposing a course of action.

These examples underscore the importance of context in determining whether statements constitute impermissible advice-giving. At least two main aspects of context are critical to this determination: the identity of the unrepresented party and the setting in which the attorney's statement is given.

85. Instructive in this context are the definitions of "advice" and "advise" appearing in Black's Law Dictionary. "Advice" is defined as "[v]iew; opinion; information; the counsel given by lawyers to their clients; an opinion expressed as to wisdom of future conduct." BLACK's LAW DictionARY 50 (5th ed. 1979). To "advise" means "[t]o give an opinion or counsel, or reconımend a plan or course of action; also to give notice." Id. 
With regard to the identity of the unrepresented person, recent court decisions have focused on the understanding of the unrepresented party. As one court put it, "That which is obvious to attorneys and judges may not be obvious to the unrepresented and economically subservient party."86 The Mississippi Supreme Court's rejection of Attorney Q's defense, that his words had merely been a genial acclamation, turned on the court's assessment of the conversation from the perspective of the unrepresented party. ${ }^{87}$ Focusing on the identity of the unrepresented party helps explain why the ABA has found improper attorney statements to spouses in divorce proceedings ${ }^{88}$ and to debtors in collection matters, ${ }^{89}$ but did not find improper statements made to a town official in the course of his official duties. ${ }^{90}$

86. In re Marriage of Foran, 834 P.2d 1081, 1088 (Wash. Ct. App. 1992). For a similar sentiment in the context of giving advice to an unrepresented adverse party through collection letters, see ABA Comm. on Ethics and Professional Responsibility, Informal Op. 1034 (1968) ("The adroit wording of the questioned paragraplss avoids any direct statement or advice as to what the final results of seeking the threatened remedies will be, and no lawyer would be likely to be misled by it. In each case, however, the over-all effect upon lay recipients of such letters probably will be, and probably was intended by the writer to be, that they had better pay up 'or else.") (quoting ABA Comm. on Ethics and Professional Responsibility, Informal Op. 734 (1964)) (internal quotations omitted).

87. See supra notes $46-53$ and accompanying text.

88. See, e.g., ABA Comm. on Ethics and Professional Responsibility, Informal Op. 1269 (1973) (holding it improper for an attorney to submit a waiver form to an unrepresented spouse in a domestic relations case if coupled with advice); ABA Comm. on Ethics and Professional Responsibility, Informal Op. 1255 (1972) (holding that an attorney should not present a responsive pleading to an unrepresented spouse for signature); ABA Comm. on Ethics and Professional Responsibility, Informal Op. 1140 (1970) (holding it improper to seek a waiver from an unrepresented defendant in a domestic relations case); ABA Comm. on Professional Ethics and Grievances, Formal Op. 58 (1931) (holding it improper to seek to obtain unrepresented spouse's consent to divorce). But see ABA Comm. on Ethics and Professional Responsibility, Formal Op. 84-350 (1984) (withdrawing Informal Ops. 1140 and 1255).

89. See, e.g., ABA Comm. on Ethics and Professional Responsibility, Informal Op. 1034 (1968) (finding letter to unrepresented defendant in personal injury case improperly offered legal advice); ABA Comm. on Ethics and Professional Responsibility, Informal Op. 734 (1964) (finding letter detailing all possible legal remedies which clients may seek threatening and improper).

90. See ABA Comm. on Ethics and Professional Responsibility, Informal Op. 83-1502 (1983). The identity of the unrepresented party was critical to the finding in Informal Opinion 83-1502. The opinion states that DR 7-104(A)(2) and Rule 4.3 "do not prohibit a lawyer from stating the lawyer's opinion on legal issues in support of the client's position," which seems to be irreconcilable with the definition of legal advice discussed above. Id. At issue in Informal Opinion 83-1502, lowever, was an attorney's letter to town commissioners threatening to sue if the commissioners repealed a certain zoning ordinance to the detriment of the attorney's client. The most compelling interpretation of this decision is that the panel was sceking a result that would permit a carefully tailored "We are going to sue you" letter to a government official. Where the government is proposing action that would affect a citizen's rights, the ability to alert the government of the adverse consequences miglt well implicate constitutional rights-including due process and First Amendment concerns-that would not arise where private parties are the targets of the letter or statement. Even in the letter to the town commissioners, however, the statements of the legal opinion are permitted only if they do not contain "false statements of fact or law," and are "not preferred [sic] as 'advice' to the unrepresented person...." Id. Of course, the latter clause may be the exception that swallows the rule, suggesting that the decision should be given a very narrow reading. If giving one's opinion as to the law 
Though given less attention in the decisions, the setting of the attorney's comments is a second critical factor in determining whether a statement is proper. As one judge explained, "Obviously, specific advice given to an unrepresented party in a formal office setting carries more weight than general advice given at a cocktail party." Similarly, an attorney's statement may have a different effect on an unrepresented litigant at the courthouse immediately prior to trial than in a letter in advance of litigation. More leeway is appropriate for the letter because the letter may serve a legally required purpose and may be distant in time and location from the court action. ${ }^{92}$ The unrepresented party has time to ask others about the statement's meaning. In contrast, statements made im the heat of negotiation, minutes before trial, may be heard as a command with which the unrepresented person has no real way of knowing whether she should, or must, comply at that moment. Thus, the setting is critical in analyzing the propriety of the communication.

A comparison of the list of permissible examples of communication with the list of potentially inappropriate behavior reveals that communications between an attorney and an unrepresented person with adverse interests are potentially rife with misconduct. As noted above, the list of appropriate communications is extremely short. In contrast, prohibitions are numerous. The attorney must refrain from giving an opinion as to the applicability of the law to the case. The attorney must refrain from suggesting a proposed course of action, whether that entails something the unrepresented person should or should not do. ${ }^{.3}$ The attorney must not mislead the unrepresented person, and must refrain from overreaching. In assessing whether the behavior or statements have "crossed the line," the assessment must be made from the point of view of the unrepresented person. This inquiry, in turn, will depend on

constitutes advice, and giving one's opinion as to the law is permissible so long as no advice is given, the test is circular.

91. Franko v. Mitchell, 762 P.2d 1345, 1360 (Ariz. Ct. App. 1988) (Grant, J., concurring in part and dissenting in part) (examining whether a potential client had reasonably relied on an attorney's comments for the purposes of a legal malpractice claim).

92. For example, such letters or notices may be required as prerequisites to eviction proceedings, consumer protection actions, etc. See, e.g., N.Y. REAL Prop. § 232-a (Consol. 1995); MASS. GEN. LAwS ANN. ch. 186, §§ 11-12 (West 1991); MASS. GEN. LAws ANN. ch. 93A, § 9(3) (West 1984). The purpose of the letter or notice is to advise the rccipient that, under the law as applied to the facts alleged, a person has been aggrieved and legal action will ensue unless the matter is rectified. This "opinion" as to the applicability of the law to the facts would seem to constitute legal advice in the classic sense. As a result, where a lawycr prepares the letter or notice, the prohibitions of DR 7-104(A)(2) or Rule 4.3 would apply. As with the analysis above, relating to the "We are going to sue you" letter to a governmental official, such a statement would necessarily be permissible, as long as it does not otherwise advise, mislead, overreach, or misstate the law or facts.

93. The exception, of course, is the advice to obtain counsel. See MODEL CODE or Professional ResponsibiLITY DR 7-104(A)(2) (1981). 
the characteristics and legal sophistication of the unrepresented party, as well as the setting in which the behavior or comments occur. Depending on the circumstances, all communications beyond the short list of permissible ones might fairly coinprise impermissible advice. ${ }^{94}$

That only a limited number of potential communications between an attorney and an unrepresented person is permissible should be neither surprising nor troublesome. It is not surprising that the ethical rules should so limit communications, given the power imbalance between an attorney, presumably very familiar with the law and the legal system, and an unrepresented person, potentially unfamiliar with the system and legally unsophisticated. The potential for overreaching and misleading is enormous. Nor is it inappropriate that a legal system premised on an adversarial norm, with its assumption that all parties will be represented, ${ }^{95}$ should take steps to insure that attorneys do not take unfair advantage of unrepresented persons with whom they are communicating. As Judge McLaughlin has observed, "The effective operation of the adversary system relies on the assumption that the parties to a lawsuit are approximately equal in their legal representation. This rough balance, however, is entirely upset when one side appears pro se." ${ }^{.96}$ Regulating attorney communications with unrepresented parties is not only advisable, but imperative.

\section{Advice-Giving in the Context of Negotiations}

The prohibition of advice-giving has profound and troubling consequences for negotiations between a lawyer and an unrepresented adversary. Neither the Model Code nor the Model Rules contains any provisions directly regulating negotiations. ${ }^{97}$ In the words of one

94. For a discussion of the limits of DR 7-104(A)(2) in the context of trust terminations, see Dobris, supra note 8, at 47-49 ("The Code does, however, allow some communication with an unrepresented litigant so long as no advice is given. How mucl communication it allows is unclear. ... The only sure way for a lawyer to avoid a post-settlement claim of either de facto representation or overreaching is to interact very little with the unrepresented beneficiary.").

95. See, e.g., Model Code of Professional Responsibility EC 7-18 (1981) (stating that lawyers should not undertake to give advice to a person who is attempting to represent himself except to advise him to obtain a lawyer).

96. Joseph M. McLaughlin, An Extension of the Right of Access: The Pro Se Litigant's Right to Notification of the Requirements of the Summary Judgment Rule, 55 FoRDHAM L. REV. 1109, 1124 (1987) (footnotes omitted).

97. See, e.g., Perschbacher, supra note 4, at 97-98 ("[T]he current ethical rules contain no provisions specifically applicable to lawyers' negotiations."); Rubin, supra note 5, at 578 ("Neither the Code of Professional Responsibility nor most of the writings about lawyers' ethics specifically mention any precepts that apply" to negotiations).

For a discussion of the proposed sections of the Model Rules devoted to the negotiating lawyer, which were deleted or modified in the final version, see Perschbacher, supra note 4 , at $97 \mathrm{n} .119$. 
commentator, "legal ethics has been little concerned with lawyers as negotiators." 98

Negotiations, however, constitute communications within the meaning of DR 7-104(A)(2) and Rule 4.3. The ethical rules recognize no exception to the prohibition against advice-giving for communications during negotiations. Nor should any such exception exist. The pressured, unmonitored negotiation, minutes before trial, is the setting in which the unrepresented litigant needs the most protection, not the least. The need for protection extends to negotiations that take place, unmonitored, in law offices or other settings as well.

The ethical strictures, if followed, make negotiation with an unrepresented adversary difficult, but not impossible. To avoid impropriety, attorneys should first clarify that they represent the adverse party. They may then advise the unrepresented litigant to obtain independent legal advice. They may also inform the unrepresented party of the terms on which their client will settle, and that the client may consider additional or different terms.

An attorney must not, however, begin the process of persuasion. Efforts to persuade the unrepresented litigant to adopt certain terms will constitute impermissible advice-giving because they constitute proposing a course of action. Efforts to justify the lawyer's negotiating position by referring to the strength or weakness of the parties' claims or by predicting what will happen in court also will constitute impermissible advice-giving because the lawyer will be giving an opinion as to the applicability of the law to the facts of the case. Further, the lawyer must refrain from overreaching, misleading, pressuring, and threatening in the course of negotiation with an unrepresented party.

A brief review of the negotiation process reveals the extent to which a prohibition against giving advice to an unrepresented adversary seriously constrains traditional negotiation. One legal negotiation text defines the negotiator's goal as ascertaining how "the other party and his negotiator [can] be convinced, persuaded, enticed or threatened into agreeing to a negotiated settlement which is desirable for the negotiator's client." ${ }^{\prime 99}$ A different text teaches that the process of persuasion is central to the negotiation process and involves the "manipulation of the decision-making process," by means including "argument, appeal,

98. Perschbacher, supra note 4, at 96. For a general discussion of how the Model Rules fail adequately to regulate lawyer behavior in the context of negotiations, see Lowenthal, supra note 5, at 411-30. "In the context of negotiation ethics ... the Rules permit or require lawyers to ignore legal duties in several circumstances when those duties conflict with client interests or with lawyers' own interests." Id. at 413. See generally Hazard, supra note 5; Rubin, supra note 5.

99. GrFFORD, supra note 10 , at 7 . Note the assumption that the opposing party is represented by a "negotiator," and, presumably, a lawyer. 
threat, and promise." 100 Another instructs, "Effectiveness in legal negotiation requires presenting the issues in a strategically favorable light and selectively controlling the flow of information."101

It is reasonable to infer that negotiations between a lawyer and an unrepresented adverse party routinely involve some, if not all, of the tactics central to the negotiation process. The purpose of negotiation is to persuade the unrepresented party to adopt a course of action. Along the way, lawyers can be expected to suggest the consequences of a failure to settle. This behavior is indistinguishable from stating an opinion as to the law applicable to the subject inatter of the case, the most narrow definition of legal advice. Similarly, lawyers often present legal and factual issues in a strategically favorable light, selectively controlling the flow of information. Lawyers also use manipulation, argument, appeals, threats, and promises.

The behavior recommended by negotiation texts, and routinely employed in negotiations, goes far beyond permissible communications with an unrepresented party. Yet cutting off negotiations altogether and forcing to trial all cases between a lawyer and an unrepresented adversary is probably not in anyone's interest, including the unrepresented party. It therefore may be tempting to refine the current limitations on advice-giving rather than to enforce those limitations and constrain negotiations. It cannot follow, however, that attorneys may persuade, mislead, cajole, pressure, and advise unrepresented adversaries, or may overreach in their dealings with unrepresented parties, particularly when the litigant has no realistic opportunity to obtain independent legal advice. Such opportunity is limited particularly where the litigant is indigent and appears pro se due to a shortage of available counsel for the poor. When negotiations occur in a hallway, minutes before trial, the unrepresented litigant must decide inmediately whether

100. Bastress \& HARBaugh, supra note 4, at 429, 433. All of Chapter 18, covering roughly one-quarter of the pages in the negotiation section of the book, is dedicated to, and titled, "The Process of Persuasion." The concepts of persuasion and argument, not surprisingly, are central to other negotiation texts. See, e.g., Bellow \& Moulton, supra note 10, at 149-69; GiFford, supra note 10, at 141-57, (discussing the use of arguments, threats and promises in the context of competitive and cooperative negotiating tactics); TEPLY, supra note 10, at 154 ("In conceptualizing the case, the negotiator thus needs to paint a picture with enough credibility to raise the fear in the opponent that what is projected... might just happen.... [Cooperative negotiators] use rational, logical persuasion as a means of seeking cooperation.").

Although it is beyond the scope of this Article to discuss different negotiating strategies and styles labelled by various scholars and analysts as "competitive," "cooperative," "adversarial," and "problem-solving," the process of persuasion, and even manipulation of the facts and law would seem to be central to the process regardless of the negotiator's style and strategy. See, e.g., BASTRESS \& HARBAUGH, supra note 4, at 429 ("Whether your style is competitive or cooperative, whether your strategy is adversarial or problem-solving, to be an effective negotiator you must persuade your opponent.").

101. TEPLY, supra note 10 , at 156. 
to settle or proceed to trial. Unrepresented litigants may give up their rights and claims and suffer unjust outcomes that cause great harm to them and their families, all at the hands of unethical attorneys who ignore their professional duties. The dangers inherent in negotiations between a lawyer and an unrepresented party underscore the need for the profession to scrutinize such scenarios rather than to ignore them. The rules that apply to negotiations between lawyers are not and should not be the same as those governing negotiations between a lawyer and an unrepresented adversary. ${ }^{102}$

With these considerations in mind, we turn to the operation of the Housing Courts of New York City. ${ }^{103}$ The cases in the Housing Courts routinely involve unmonitored hallway settlement negotiations between landlords' lawyers and unrepresented tenants. The tenants typically are poor women of color. The hallways are crowded, the facilities are decrepit, and the pressure to settle is intense. These circumstances are ripe for impermissible advice-giving.

II

The Prohibition of Advice-Giving in Context

\section{A. The New York City Housing Courts: The Setting}

"The halls were jammed with people clutching eviction notices and the volume was headache-inducing: babies wailing, court officers yelling out cases, and landlord's lawyers and tenants negotiating rents in full cry in the stairwells." 104

102. See Gary Bellow \& Jeanne Kettleson, From Ethics to Politics: Confronting Scarcity and Fairness in Public Interest Practice, 58 B.U. L. Rev. 337, 387 n.195 ("The most ardent proponent of the present adversary system does not argue that it requires a lawyer to take advantage of an opponent who, without counsel, does not have the same opportunities to be informed and counselled.").

103. Ethics decisions arising from New York have been consistent with those from the ABA and other courts. See W.T. Grant Co. v. Haines, 531 F.2d 671 (2d Cir. 1976); see also N.Y. State Bar Ass'n Comm. on Professional Ethies, Op. 358 (1974) (cited in Haines, 531 F.2d at 676 n.3). One subsequent decision cites Opinion 358 as prohibiting "legal advice," N.Y. State Bar Ass'n Comm. on Professional Ethics, Op. 663 (1994), while another cites it as prohibiting all advice other than the advice to obtain counsel, N.Y. State Bar Ass'n Comm. on Professional Ethics, Op. 607 (1990). See also N.Y. State Bar Ass'n Comm. on Professional Ethics, Op. 650 (1993) (regarding a corporate attorney's proposed participation in a "compliance with law" program under which employees are required to report illegal or unethical behavior, "[i]f the caller is not represented by counsel in this matter, the attomey cannot give any further advice other than the advice to secure counsel") (citing Model Code of Professional Responsibilty DR 7-104(A)(2) (1981)); N.Y. State Bar Ass'n Comm. on Professional Ethics, Op. 478 (1978) (under certain circumstances, lawyer may prepare and transmit separation agreement to unrepresented adverse party for signature; lawyer may discuss settlement of pending matrimonial litigation with unrepresentcd adverse party where that party appears pro se).

104. Jan Hoffman, Chaos Presides in New York Housing Courts, N.Y. TmES, Dec. 28, 1994, at AI (describing Brooklyn Housing Court). 
"Approximately 50 people waiting for elevators.... Overcrowding, kids crying, smoke-filled corridor. Landlords, attorneys, and tenants making deals in the hallway.... Very crowded. The courtroom looked like a bus depot. Attorneys reading newspapers, people talking, a lot of people just standing around." 105

"[T]he court has degenerated into a hapless collection of brokendown court buildings where landlords and tenants routinely bang out hasty agreements im overcrowded hallways filled with screaming babies, angry lawyers and a babble of different languages."106

"Crumbling walls. Peeling paint.... The court from hell, Housing Court."107

The Housing Court was created by the New York state legislature with the stated purpose of providing adequate judicial procedures for the effective enforcement of proper housing standards in the City of New York and to protect the health, safety and welfare of the citizens of the State. ${ }^{108}$ On paper, eviction proceedings-referred to as summary proceedings-comprise only one of the numerous types of housing cases over which the Housing Court has jurisdiction. ${ }^{109}$ In reality, summary proceedings dominate the court's docket. ${ }^{110}$

The Housing Court's volume is crushing. The volume of cases filed annually varies from 300,000 to almost $400,000.11$ Such a volume

105. Monitoring Subcommittee, City Wide Task Force on Housing Court, 5 Minute Justice OR "Ain't Nothing Going on But the Rent!" 22 (1986) [hereinafter 5 Minute JUSTICE] (describing first and fourth floors of Brooklyn Housing Court).

106. Dave Saltonstall, Housing Crisis: Those Who Go Courting Justice Find It Can Be Had for the Right Price, Daily News (N.Y.), Feb. 25, 1996, at 24.

107. Rita Giordano, A Look Inside Tenants' World, NEwSDAY (N.Y.), Apr. 2, 1992, at 27.

108. See N.Y. CrTY Crv. Cr. ACr $\$ 110$ (Consol. 1995). "Housing Court" is the common name used to refer to what technically is the "Housing Part of the New York City Civil Court." Housing Court Judges, although called "judges," are in reality nonjudicial officers of the court, appointed for five-year terms. Id. § 110(i). Aspects of the housing cases are also heard by Civil Court Judges, elected for ten-year terms. Id. § 110(e).

109. Id. § 110(a).

110. See Anthony M. DeStefano, In Housing Court, Justice in a Jam, NEwsDAY (N.Y.), June 1, 1993, at 7 ("About 90 percent of the 321,000 cases filed in Housing Court last year [1992] concerned overdue rent, said Ernesto Belzaguy, the chief clerk of the court."); Saltonstall, supra note 106, at 24 ("These days, the arguments before the court are almost never over repairs. Virtually all focus on one issue: nonpayment of rent."); see also 5 MiNUTE JUSTICE, supra note 105, at $46-47$ (citing mid1980 s study of Housing Court finding that well over $80 \%$ of the cases filed were either nonpayment proceedings or holdover proceedings, the two major categories of "eviction" cases).

111. See 144 Woodruff Corp. v. Lacrete, 585 N.Y.S.2d 956, 960 (N.Y. Civ. Ct. 1992) (citing Committee on Legal Assistance, Association of the Bar of the City of New York, Housing Court Pro Bono Project, Part II, at 19-22 (Nov. 1988) [hereinafter Pro Bono Project Part II] (unpublished manuscript)) (finding that nearly 400,000 cases were filed in 1985); Community TRAINING \& Resource Ctr. \& City-Wide Task Force on Housing Court, Inc., Housing Court, Evictions and Homelessness: The Costs and Benefits of Establishing a Right to Counsel iii (1993) [hereinafter Housing COURT, Evictions AND HoMelessness] (noting approximately 300,000 Housing Court actions per year); DeStefano, supra note 110, at 7 (noting 
leads to a "jurisprudence of ultimate expedition."112 By one estimate, each housing judge handles over 12,000 cases per year, or an average of $331 / 3$ per day. ${ }^{113}$ "These cases are disposed of at an average rate of five to fourteen minutes per case, with many settlements in the range of five minutes or less."114 According to one study, $34.4 \%$ of the cases lasted less than five minutes, while $71.7 \%$ of the cases lasted less than fifteen minutes. ${ }^{115}$

Adding to the overwhelming volume are the horrible physical conditions. "Overcrowded, dirty, poorly ventilated, inadequate seating" are among the problems cited. ${ }^{116}$ Judge Jacqueline Silbermann, who until 1996 was the Administrative Judge of the New York City Civil Court, which oversees Housing Court, has conceded that " $[t]$ he physical plant is just atrocious." 117

The observations of New York's top judges and administrators about the setting in the New York Housing Courts are particularly telling. Current Court of Appeals Judge, and former Chief Administrative Judge, Joseph Bellacosa once referred to the Bronx Housing Court as "an absolute horror show."118 Sol Wachtler, former Chief Judge of the New York State Court of Appeals, once termed the overcrowding and "pedestrian gridlock" in the Housing Courts as "reminiscent of a bazaar of Calcutta." 119 The setting is capable of rendering the most legally sophisticated and economically secure unrepresented litigant vulnerable to a lawyer's pressure. Typically, however, the unrepresented litigants are neither legally sophisticated nor economically secure.

approximately 321,000 cases in 1992); Hoffman, supra note 104, at A1 (noting 330,000 cases a year for 35 judges).

112. 144 Woodruff Corp., 585 N.Y.S.2d at 960 (quoting Pro Bono Project Part 1I, supra note 111, at 20).

113. Id. This figure compares to 263 cases per year for Supreme Coart Justices, the judges in New York's courts of general jurisdiction. On the date of the stipulation in question in 144 Woodruff Corp., the court had 36 cases on its calendar. 585 N.Y.S.2d at 960 . The court ultimately vacated the stipulation. Id. at 961 . In some instances, judges handle as many as 80 cases in a single day. See Hoffman, supra note 104, at A1.

114. 144 Woodruff Corp., 585 N.Y.S.2d at 960; see also Hoffman, supra note 104, at AI ("litigants 'receive less than five minutes of attention' each from the judges") (quoting an October 1994 report by the Fund for Modem Courts).

115. See 5 Minute Justice, supra note 105 , at 51.

116. Id. at 20.

117. Saltonstall, supra note 106, at 24. An October 1994 report by the Fund for Modern Courts found the facilities "grossly inadequate." Hoffman, supra note 104, at A1.

118. 5 MINUTE JUSTICE, supra note 105 , at 20.

119. Access to Justice Project, American Civil Liberties Union, Justice Evicted: AN INQUiRY INTo Housing COURT Problems 26 (1987) [hereinafter Justice Evicted] (internal quotations omitted). 


\section{B. The Litigants In The New York City Housing Courts}

In most cases in New York City's Housing Courts the landlord is represented by counsel, while the tenant is forced to appear without counsel. Landlords are represented in approximately ninety percent of the cases. ${ }^{120}$ In contrast, tenants are unrepresented in close to ninety percent of the cases, and, by some estimates, in greater than ninety percent of the cases. ${ }^{121}$ Hence, the typical case in Housing Court pits a represented landlord against an unrepresented tenant. ${ }^{122}$ Often, the landlord does not actually appear in court, leaving the landlord's lawyer and the unrepresented tenant as the sole participants in the proceeding. ${ }^{123}$

Tenants in Housing Court are overwhelmingly poor women of color. ${ }^{124}$ Housing Court itself is typically referred to as a "poor people's court,"125 and the statistics dramatically underscore the poverty of the tenants. ${ }^{126}$ Over eighty-five percent of the tenants are African-

120. See id.; see also 144 Woodruff Corp. v. Lacrete, 585 N.Y.S.2d 956, 958 (N.Y. Civ. C. 1992) ("Studies have shown that landlords are represented in approximately eighty to ninety percent of summary eviction proceedings...."); Housing CoURT, Evicrions AND HOMELESSNESS, supra note 111, at iv (citing a 1993 study reports that landlords are represented by attorneys in $97.6 \%$ of the cases). Landlords are represented least often in Brooklyn and most often in the Bronx and Manhattan. See id.; 5 MiNuTE Justice, supra note 105, at 41 tbl.4.14.

121. See 144 Woodruff Corp., 585 N.Y.S.2d at 958 ("Studies have shown that ... tenants are unrepresented in all but ten to fifteen percent of [summary eviction] proceedings."); 5 MiNUTE JusTiCE, supra note 105, at 28 (quoting housing court judge outraged that " 95 percent of the landlords [were] represented by attomeys, and only 5 percent of the tenants [were]"); Housing CourT, Evictions AND HoMElesSNESS, supra note 111, at 13 (reporting that between 9.4 and $11.9 \%$ of tenants were represented by attorueys); Richard J. Meislin, In City Housing Court, Focus Is Now More on Evictions Than on Rents, N.Y. Times, Feb. 4, 1986, at B1 (statement of Judge Israel Rubin, the former Chief Administrative Judge of the Civil Court, that "90 percent of the tenants are unrepresented.").

As with the case of representation of landlords, the figure varies from borough to borough. Tenants are most likely to be represented in Manhattan, and least likely to be represented in the Bronx. Even in Manhattan, however, "more than eight out of ten tenants there were without counsel." Housing CouRT, Evicrions AND HoMElEsSNESS, supra note 111, at iv; see also 5 MiNUTE JUSTICE, supra note 105 , at 39 tbl.4.10.

122. See 5 Minute Justice, supra note 105 , at 41 ("when a landlord is represented by an attorney 73 percent of the tenants are not represented"); JusTice EvicTED, supra note 119, at 20 ("In fact, the most common situation was that of a landlord with a lawyer facing a tenant without one."). Even using the conservative figures of $80 \%$ representation of landlords and a similar figure of $80 \%$ unrepresented tenants, and assuming further that represented landlords never face represented tenants, $60 \%$ of the cases would pit an unrepresented tenant against a represented landlord. With estimates closer to, or exceeding, $90 \%$, that figure is cousiderably higher.

123. See 5 MinUTE JUSTICE, supra note 105 , at 40 tbls.4.11 \& 4.13 (reporting that 865 of 1487 , or $58 \%$, of landlords or their agents were present in court).

124. See 144 Woodruff Corp., 585 N.Y.S.2d at 958 ("[T] unrepresented tenants are poor persons, most of whom are members of racial and ethnic minorities."); 5 MINUTE JUSTICE, supra note 105, at 31 ("Minority women made up the single largest group of tenants: 56 percent of all tenants were black, hispanic or asian women.").

125. See, e.g., Hoffman, supra note 104, at A1.

126. See HOUSING COURT, Evictions AND HOMELESSNESS, supra note 111, at iii ("Tenants with incomes below $\$ 10,000$ comprise 47.9 percent of the Housing Court population. Only 18 percent of 
Americans and Latinos. ${ }^{127}$ Women comprise anywhere from two-thirds to four-fifths of the tenant population. ${ }^{128}$ Many tenants have a limited understanding of English, let alone legalese. ${ }^{129}$ White tenants and male tenants are more likely to be represented than female tenants or tenants of color. ${ }^{130}$ Unrepresented tenants therefore disproportionately come from groups that have experienced bias and powerlessness both inside and outside the legal system. ${ }^{131}$ This demographic makes unrepresented tenants particularly vulnerable in their encounters with opposing counsel.

\section{Negotiations Between Landlords' Lawyers And Unrepresented Tenants In The New York City Housing Courts}

Analysis of negotiations that occur in a hallway setting is difficult. The setting is unmonitored: no third party records the communications by the attorneys, and no transcripts exist. As a result, it is difficult to determine precisely the extent to which landlords' lawyers violate the prohibition against advice-giving to unrepresented tenants. The inquiry remains critical, however, because "most cases are settled with only minimal supervision by the court."132 Observation of New York's Housing Courts compels the conclusion that violations of the prohibi-

the tenants have incomes over $\$ 25,000 . \ldots 68.7$ percent of the households facing eviction have household incomes at or below $\$ 19,000$ a year.").

127. See id.:

The majority (57.5 percent) of tenants in Housing Court are African-Americans. Latinos represent an additional 29.1 percent of the tenants, while non-Latino Whites and Asians account for 10.8 and 1.0 percent of the tenants respectively. Of the four boroughs studied (Manhattan, Brooklyn, the Bronx and Queens), the Brooklyn Court had the highest percentage of Afriean-American tenants. The largest proportion of Latino respondents were in the Bronx.

People of color are represented in the pool of respondents in Housing Court in far greater numbers than their proportion in the population at large.

128. Figures on the number of women tenants in the Housing Court vary from $66.4 \%$ to $79.0 \%$. See 5 MinUTE Justice, supra note 105, at 33; Justice EviCTED, supra note 119, at 19.

129. See, e.g., Cabbad v. Melendez, 438 N.Y.S.2d 120, 121 (N.Y. App. Div. 1981) (vacating stipulation because "the non-Englisb speaking tenant... in the absence of counsel" entered into consent judgment "inadvertently, unadvisably or improvidently"); Jan Hoffman, New York's Court Interpreters: Ovenworked Link, N.Y. TIMEs, Dec. 24, 1993, at A1 ("In Brooklyn Housing Court linguistic confusion meets desperation on a daily basis. The other day the corridor outside Judge Lau's courtroom was rocked by scared, angry voices in many languages. Lawyers for landlords strained to be heard, screeching legalese: 'Just sign this stip, O.K.?' The frequent refrain: 'No understand.").

130. Whereas $32.7 \%$ of white tenants were represented, only $17.3 \%$ of Black tenants and $18.6 \%$ of Hispanic tenants were represented. See 5 Minute Justice, supra note 105, at 35. Men were represented in a slightly higher percentage of cases than women: $23.5 \%$ to $21.0 \%$. See id. at 36 .

131. See, e.g., supra note 14 and accompanying text; infra notes 313-318 and accompanying text.

132. 144 Woodruff Corp. v. Lacrete, 585 N.Y.S.2d 956, 960 (N.Y. Civ. C. 1992); see also Coalition for the Homeless et al., Stemming the Tide of Displacement: Housing Policies for Preventing Homelessness 63-64 (1986) [hereinafter Stemming the TIDE]; 5 Minute Justice, supra note 105 , at 57. 
tion against advice-giving to an unrepresented adverse party are widespread.

The Housing Court setting renders unrepresented tenants particularly susceptible to overreaching landlords' lawyers. The settlements occur "away from the courtroom in the hurly-burly of the hallway."133 The enormous volume of cases, poor facilities, and high level of stress render the setting burdensome for virtually everyone. Many unrepresented tenants face the additional difficulty of coming to Housing Court with their children in tow. Additionally, some have a limited understanding of English. Even those who do understand English often do not grasp the complexities of the law. ${ }^{134}$

The comments of observers reveal improper attorney behavior even under a narrow interpretation of impermissible advice-giving. A number of observers reported that landlords' attorneys engaged in behavior that is, at a minimum, overreaching:

Ninety percent of tenants do not have lawyers and manywho inay not speak English, much less know their rights-are bullied into signing hallway agreements by landlords' lawyers brandishing cellular phones, calculators and legal papers....

On the fourth-floor hallway, some tenants were backed against walls by landlords' lawyers waving a consent document known as a stipulation, or, in the slang of the court, a "stip." 35

In another account, "Landlord's lawyer ... went into an interrogation of tenant. Really pressuring tenant." ${ }^{136}$ Were transcripts of encounters available, it would not be surprising to find statements that would constitute an opinion as to a proposed course of action, an opinion as to the applicability of the law to the facts, or even misleading statements as to the law and facts.

Some observations reflect the tenants' confusion as to whether the attorney was in one case the mediator and in another the judge.

[A] short, wiry white man in a dark, double knit suit, his tie already loosened at 9:30 in the morning, stands in front of the bench calling out names. The first ten bring no answer. The eleventh yields an eager black man with a mock-fur hat. $\mathrm{He}$ rnshes up to the white man and identifies himself.

133. Catherine T. Brody, In Housing Court: Not a Clue, N.Y. T1MEs, Sept. 25, 1994, at B21.

134. New York's housing laws are so complex that the New York Court of Appeals has referred to them as an "impenetrable thicket, confusing not only to laymen but to lawyers." 89 Christopher, Inc. v. Joy, 318 N.E.2d 776, 780 (N.Y. 1974); see also 144 Woodruff Corp., 585 N.Y.S.2d at 960 ("[T]t is unreasonable and unfair to assume that unrepresented parties are able to understand the legal possibilities that exist at any stage of a proceeding.") (quoting Pro Bono Project Part 1I, supra note 111 , at 12-13).

135. Hoffman, supra note 104 , at A1.

136. 5 MinUTE JUSTICE, supra note 105 , at 67 . 
"Yes, that's me, sir," he whispers.

There is some discussion, apparently about money, which I cannot hear completely, then: "Sign this stip, and you can go," the white man explains, not looking at him.

The black man signs quickly, says, "Thank you, Your Honor," and rushes out.

His Honor is not a judge. He is . . counsel to the landlord in this case. [He] has just gotten his tenant/opponent to sign some sort of stipulation in an eviction proceeding that the tenant had ... been fighting. ${ }^{137}$

This behavior is, at a minimum, misleading as to the facts under DR 7104(A)(2). ${ }^{138}$ The behavior also violates Rule 4.3 of the Model Rules, which prohibits a lawyer from stating or implying that the lawyer is disinterested and requires the lawyer to make reasonable efforts to correct a misunderstanding as to the lawyer's role. ${ }^{139}$ Finally, this encounter illustrates the power disparity between unrepresented tenants and landlords' lawyers. The attorney's authority in the courthouse goes unquestioned by the tenant. Without counsel, disenfranchised parties agree to settlements without knowing their rights or understanding their cases. $^{140}$

The observed attorney comments and behavior effectively propose a course of action to the unrepresented tenant: the signing of a stipulation. The communications attempt to persuade the tenant to sign the stipulation: "Just sign this stip, o.k.?"141

"If the judge sees this doubtful look on your face or he thinks I'm taking advantage of you, it'll take hours," crooned a lawyer to a young woman. "But if you say you understand, we'll be out of here. You know I'm being a good guy and we're not fighting, right?" She looked doubtful and scared, but signed the stipulation. The lawyer grabbed it and dashed into a courtroom..$^{142}$

137. Steven Brill, The Stench of Room 202, AM. LAW., April 1987, at 1, 15; see also 5 MiNUTE Justice, supra note 105, at 67 ("The landlords' lawyers are calling the cases as if they are the [mediators].").

138. See ABA Comm. on Professional Ethics and Grievances, Formal Op. 102 (1933).

139. See Model Rules of Professional Conduct Rule 4.3 (1983). The lawyer observed to have been mistaken for the judge later was asked why he had allowed the tenant to think he was the judge. He replied, "I always introduce myself. ... You must not have ... heard me. It's impossible that he thought I was the judge.... Sometimes people in court call lawycrs "Your Honor." Brill, supra note 137, at 15 (alteration in original). Even assuming that he had properiy introduced himself-an assumption not particularly compelling since the entire encounter was observed-the lawyer made no effort to correct, let alone recognize, the misunderstanding.

140. For a description and analysis of a similar power disparity during negotiations in Boston Housing Court between landlords' lawyers and unreprescnted tenants, see Fox, supra note 14.

141. Hoffman, supra note 129 , at A1.

142. Hoffman, supra note 104 , at A1. 
Suggesting to an unrepresented tenant how she should behave before the judge, reminding her that "we'll be out of here" if she acts a certain way, and reassuring her that the attorney is a good guy all amount to proposing a course of action: that the tenant sign the stipulation. The comments succeeded in inducing the tenant-looking "doubtful and scared"-to adopt the attorney's proposed course of action and sign the stipulation.

It would be comforting to conclude that the impermissible attorney behavior described above constitutes only an extreme, undertaken by a few isolated attorneys. One could then be content that, while steps need to be taken to deal with a few bad apples, the misconduct does not permeate the court's fundamental structure. The available information, however, indicates that such impermissible behavior is widespread. Moreover, a closer analysis of the negotiation process in New York City's Housing Court reveals that behavior far less extreme than the behavior observed would constitute impermissible advice-giving.

The comments of regular observers of, and participants in, the Housing Court suggest that improper attorney behavior is the rule, rather than the exception. ${ }^{143}$ As noted previously, according to one report, "[n]inety percent of tenants do not have lawyers and many ... are bullied into signing hallway agreements by landlords' lawyers."144 The consistent examples of attorney misconduct underscore the widespread nature of the behavior. The City-Wide Task Force on Housing Court has reported that '[1]andlords' lawyers are in the habit of aggressively approaching tenants in the courtroom (which is usually in chaos) or in hallways, and persuading them to sign stipnlations." 145 According to tenant advocates:

The result is a lopsided system in which unrepresented tenants routinely are approached by landlord attorneys in court hallways and pressured to sign complicated settlements that in many cases they cannot read, much less understand .... ${ }^{146}$

143. Having practiced in Brooklyn Housing Court for nine years, and having spoken with numerous people familiar with the New York City Housing Courts, I count myself as a regular observer of the courts. I have no doubt that the behavior is a common feature of the court's operation. The presence of such rampant misconduct despite the existence of ethical rules that purport to prohibit the misconduct led me to write this Article.

144. Hoffman, supra note 104 , at A1.

145. 5 MINUTE JUSTiCE, supra note 105, at 73. "Once the stipulation is written, the tenant is expected to read and sign it on the spot. It is unheard of for a tenant to take the agreement away to read it thoroughly before signing it." Id. at 59.

"The result, advocates said, is that tenants fail to defend themselves properly, are easily pressured and manipulated by landlord attorneys, and in some cases, judges accept unreasonable settlements because of the high-pressure tactics in courthouse corridors, where an attorney thrusts a piece of paper at a bewildered tenant and says 'sign this."' DeStefano, supra note 110, at 7 .

146. Saltonstall, supra note 106 , at 24. 
Attorneys from one legal services office have described the hallway negotiations as follows:

Once the landlord's attorney does appear in the trial part, he will almost always engage in a settlement discussion with the pro se tenant without the judge or the judge's law assistant being present. No court-appointed translators are available to assist pro se tenants in these settlement discussions. The landlord's attorney will invariably focus solely on the ainount of rent claimed owed by the landlord, and will frequently mislead the pro se tenant into believing that she has no option but to agree to the terms he is proposing. ${ }^{.47}$

The agreements themselves-the products of the hallway negotiations-provide further evidence of the widespread nature of the observed attorney behavior. An extensive body of law has einerged in which judges vacate stipulations previously entered into by a landlord's lawyer and an unrepresented tenant. ${ }^{148}$ The court inay exercise its discretion to vacate stipulations that are unduly harsh or one-sided. ${ }^{149}$ Since the current ethical rnles do not prohibit obtaining an unconscionable or one-sided agreement, ${ }^{150}$ the mere existence of an unduly one-sided agreement does not constitute an ethical violation. The agreements, however, result from unmonitored, hallway encounters between lawyers and unrepresented tenants. Landlords' lawyers routinely employ tactics central to negotiation: manipulation, arguinent, appeals, threats, and promises. These tactics are all designed to persuade

147. Brooklyn Legal Services, Corporation B, Draft Verified Class Action Complaint 24-25 (1990) [hereinafter Brooklyn Legal Services, Draft Complaint] (on file with author). The description continues:

The discussion will include the need for repairs in the premises only if the pro se tenant is adamant about the repairs. The discussion will alınost never include issues regarding a pro se tenant's right to request a trial; her right to request a rent abatement based on the existence of conditions in her apartment that are dangerous to her household; her right to request an order from the court requiring the landlord to provide essential services and make necessary repairs in the apartment; her right to request the court to send an inspector to the apartment to determine whether the landlord is providing essential services or making necessary repairs; or her right to seek to dismiss the non-payment action because the Id. at 25 .

landlord has not coinplied with statutory registration requirements.

148. See, e.g., Cabbad v. Melendez, 438 N.Y.S.2d 120, 121 (N.Y. App. Div. 1981); 144 Woodruff Corp. v. Lacrete, 585 N.Y.S.2d 956, 958 (N.Y. Civ. Ct. 1992); City of New York v. Hicks, N.Y. LJ., Feb. 3, 1992, at 24 (App. Term.); GTS Holding Corp. v. Cruz, N.Y. L.J., June 25, 1987, at 12 (App. Term.); 1504 Management. Co. v. Liddie, N.Y. LJ., Apr. 28, 1986, at 7 (App. Term.); Arthur Management. Co. v. Ortiz, N.Y. LJ., Jan. 9, 1986, at 14 (App. Term.).

149. See, e.g., Solack Estates, Inc. v. Goodman, 425 N.Y.S.2d 906 (N.Y. App. Term 1979), affd, 432 N.Y.S.2d 3 (N.Y. App. Div. 1980); Amsterdam Co. v. Levy, N.Y. LJ., Mar. 9, 1987, at 14 (App. Term.); McAvoy v. Chaplin, N.Y. L.J., July 15, 1983, at 13 (App. Term.). Cf. Fed. R. Civ. P. 60(b).

150. To the contrary, proposed Rule 4.3, which would have prohibited such conduct, was not adopted. For a discussion of the proposed provisions of the Model Rules, see infra notes 277-281 and accompanying text. 
the unrepresented tenant quickly to adopt a particular course of action: settlement on terms favorable to the landlord. ${ }^{151}$

Tenants may unwittingly waive significant rights by accepting a hallway settlement agreement. Various New York State and local laws provide that a tenant may raise substantive and procedural defenses to the nonpayment proceeding, including claims such as breach of the warranty of habitability and rent overcharge. ${ }^{152}$ Yet, the agreements regularly include provisions regarding payment of rent or vacatur of the premises and ignore concerns of the tenants such as repairs or reductions in rent. ${ }^{153}$ Where tenants capitulate to the terms of a settlement agreement dictated by a landlord's lawyer, they often are inadvertently and unknowingly waiving important rights. ${ }^{154}$

This realization underscores the extent to which the attorney misconduct extends far beyond bullying tenants and backing them against the wall. Consider even a well-intentioned landlord's lawyer, negotiating calmly and respectfully, in a relatively quiet corner of the hallway. The negotiation in a typical nonpayment case might include the following exchanges. The lawyer states that the tenant owes a certain amount of rent. If the tenant disputes the amount of rent, the lawyer asks for receipts, and explains that the tenant cannot be credited for payments absent receipts. If the tenant mentions conditions in need of repair, the lawyer agrees to have the landlord inspect the apartment, but tells the tenant that the rent still needs to be paid. The lawyer also tells the tenant that if the parties do not settle, the judge may only give the tenant five days to pay before being evicted.

The lawyer's seemingly innocuous comments are riddled with the lawyer's opinion as to the applicability of the law to the facts, and therefore constitute legal advice. Statements that a certain amount of rent is

151. There is no reason, however, to assume that the cases in which the stipulations are vacated are the only ones in which unduly harsh or one-sided stipulations-and the related improper behavior on the part of the landlord's lawyer-have occurred. The cases in which stipulations are vacated usually involve cases in which the tenant initially appears pro se, and is later able to retain counsel after the stipulation has been approved by the court. See, e.g., supra notes 148-149 and accompanying text. As noted, however, very few tenants are able to obtain lawyers. See supra note 121 and accompanying text.

152. See, e.g., N.Y. MULT. DwEll. $§ 302-$ a (Consol. 1995) (abatement of rent in case of serious violations of housing code); N.Y. MuLT. Dwell. $\$ 325$ (Consol. 1995) (requiring landlords to register a multiple dwelling or have a valid Certificate of Occupancy); N.Y. Real ProP. L. \$ 235-a (tenant right to offset payments); N.Y. REAL PROP. $\S 235-\mathrm{f}$ (Consol. 1995) (breach of the warranty of habitability); N.Y. REAL PROP. ACTS. $\$ 735$ (Consol. 1995) (improper service of process).

153. See, e.g., 5 MiNuTE Justice, supra note 105, at 73-74 ("Violations were alleged by the tenant in 62.7 percent of the nonpayment cases. Only a third of the settlements were conditional on repairs. ... Even if the tenant forcefully negotiates to obtain repairs and services, there is very little likelihood that the stipulation will condition rent payment on completion of repairs.").

154. See, e.g., 5 Minute Justice, supra note 105, at 60; STEMMING THE TIDE, supra note 132, at $63-64$. 
owed or that rent must be paid in the face of poor conditions are attorney opinions. For example, they include the attorney's opinion of whether the bookkeeping is correct, whether the proper level of rent is being charged, and whether the tenant's offsetting claims, such as the breach of the warranty of habitability, have merit. The statement that the tenant must show receipts reflects the lawyer's opinion that the landlord will carry his burden of proving the arrearage, and that the tenant may ouly prove her defense of payment of rent by showing receipts. The prediction as to what the court will do similarly includes the lawyer's opinion as to whether the court will recognize and give merit to procedural defenses that could lead to dismissal of the action, rather than judgment for the landlord. The prediction also includes the lawyer's opinion as to how the judge will rule on the substantive defenses.

Each comment comprises the attorney's opinion as to the applicability of the law to the facts of the case and may also be a misleading presentation of the law or the facts. Moreover, the comments, and others that may occur in the course of the negotiation, are intended to push the tenant toward settlement on the proposed terms. The comments therefore must be seen as an effort to influence the unrepresented tenant to take a course of action. The comments constitute improper advicegiving and underscore the extent to which the typical landlord's lawyer, conducting routine negotiations with an unrepresented tenant, may engage in impermissible attorney conduct.

The typical negotiation bears little resemblance to negotiations conducted within the constraints of DR 7-104(A)(2) and Rule 4.3. Lawyers respecting the limitations on advice-giving should clarify that they are representing the landlord. They may, and perhaps should, advise the tenant to obtain legal counsel, or at least seek independent legal advice. They could inform the tenant of the terms on which the landlord will settle and the steps the lawyer (or the landlord) will take if the parties do not settle, such as going before the judge. If a tenant proposes additional or different terms, lawyers can accept the terms if they have authorization to do so. If the lawyer begins the process of persuasion, however, whether that entails explaining why the landlord is entitled to the terms, what the court inight do if there is no settlement, or why the settlement is in the tenant's interest, then the lawyer has crossed the line and is engaging in impermissible advice-giving. Even in rejecting the tenant's proposals, the lawyer must avoid suggesting that the tenant is not entitled to what she is asking.

An examination of the operation of New York City's Housing Court, in light of the prohibitions against advice-giving, yields the inescapable conclusion that most New York City landlords' attorueys are routinely violating the Code of Professional Responsibility. Although 
the focus of this Section is on situations involving a landlord's lawyer and an unrepresented tenant, much of the analysis would apply as well to situations in which the tenant has counsel and the landlord does not. That situation, however, is rare. According to one study, only three percent of housing cases involved a represented tenant and an unrepresented landlord. ${ }^{155}$ Impermissible advice-giving in New York City's Housing Court therefore arises typically in negotiations between landlords' lawyers and unrepresented tenants. Section D considers the extent to which these problems also exist in other settings.

\section{The Scope of the Problem: Beyond the New York City Housing Courts}

It may be tempting to conclude that the ethical problems in the New York City Housing Courts are limited to that venue. It would not be surprising if the crushing volume of cases and complicated legal issues make the courts unique. The inquiry is hampered by the relative absence of "data" on which to base a conclusion of widespread attorney misconduct. ${ }^{156}$ Yet available information indicates that many of the conditions that invite the impermissible behavior in New York City's Housing Courts exist in other courts that regularly pit lawyers against unrepresented litigants.

This section examines briefly three settings: housing cases outside of New York City, consumer cases, and family law cases. As will be seen, differences exist in the settings, in the nature of the cases, and in the courts. For example, housing cases outside of New York City also involve some landlords who are repeat players, and others who are infrequent players, facing predominantly unrepresented individuals, in courts dominated by the landlords' lawyers. ${ }^{157}$ Consumer cases regularly involve represented creditors, who are repeat players, against unrepresented individuals, in courts dominated by the creditors' lawyers. ${ }^{158}$ Family law cases involve individuals against individuals, sometimes with

155. See JUSTICE EVICTED, supra note 119, at 17. Another study reports that of all cases in which landlords were unrepresented (22\% of all cases), only $15 \%$ involved a represented opposing party. See 5 MinUTE JuSTiCE, supra note 105, at 40-41. In contrast to the situation involving tenants, landlords are more likely to be white and/or men. See id. at 40 . As with tenants, minority landlords were less likely to be represented. SEE JUSTICE EvICTED, supra note 119, at 20 (60\% of represented landlords were white, $82 \%$ of unrepresented landlords were Black or Latino); supra note 122 and accompanying text.

156. The absence of such data is not surprising. The courts that are likely settings for the attorney abuse are largely ignored by disciplinary bodies and scholarly writings. The attorney behavior routinely occurs in the unmonitored settings of the hallway or, in advance of litigation, entirely outside the purview of the courts.

157. See infra Part II.D.1.

158. See infra Part II.D.2. See generally Marc Galanter, Why the "Haves" Come Out Ahead: Speculations on the Limits of Legal Change, 9 L. \& Soc'Y REv. 95, 149 (1974) (describing relative success of repeat players versus one-shot players in court). 
both parties represented, sometimes with one party represented, and sometimes with neither party represented; the litigants are not repeat players, although the lawyers often are. ${ }^{159}$ Conditions inviting impermissible advice-giving are present in each setting.

\section{Housing Cases Outside of New York City}

Many of the same conditions described in New York City's Housing Courts exist in courts outside New York City that handle housing matters. For example, a recent report indicated that in fiscal year 1994, 33,392 cases were filed in the Massachusetts Housing Court Department. ${ }^{160}$ This caseload is handled by six judges, yielding a tremendous caseload per judge. ${ }^{161}$ One newspaper article described Boston Housing Court as "part bazaar, part day-care center, part Ellis Island-like reception center, part floor scene at a commodities exchange."162

Most landlords in the Massachusetts courts have lawyers, while most tenants appear without counsel. ${ }^{163}$ Unrepresented Massachusetts tenants, like their counterparts in New York, are predominantly poor, and many are women and members of racial and ethnic minorities. ${ }^{164}$ The power

159. See infra Part II.D.3.

160. See Massachusetts LaW Reform Institute, Housing Cases-What Do the Numbers Say? Housing INFormation Memo 11-12 (Apr. 1995) (citing 1994 ANNUAL ReporT on the STate of THE MassachusetTs Court SYSTEM (1995)).

161. See id. If the cases are evenly distributed, each judge would handle roughly 5,565 cases per year. On any given day, the caseload could exceed the 33 cases per judge involved in New York City. One report stated that more than 200 cases were heard by a single judge on the weekly calendar. Adrian Walker, Improved Economy Tied to Rise in Evictions, Boston GLOBE, Sept. 27, 1994 , at 25 .

162. Alan Lupo, Playing Solomon to Those Caught in the Shrinking Rental Market, BostoN GLOBE, May 28, 1988, at 13; see also Fox, supra note 14, at 91-92.

163. The 1995 report found that landlords were represented by lawyers in $66.7 \%$ of the 375 reviewed cases, while tenants were represented in only $11.5 \%$. See MASSACHUSETTS LAW REFORM Institute, Summary Process Survey 4 (1995) [hereinafter MLRI Sumrary Process Survey]. A study of 500 cases from the early 1980s found that Iandlords had counsel in $73.8 \%$ of the cases, while tenants had counsel in only $13.6 \%$ of cases in Boston's housing courts. Russell Engler \& Craig S. Bloomgarden, Summary Process Actions in the Boston Housing Court: An Empirical Study and Recommendations for Reform 5 (May 20, 1983) (unpublished manuscript, on file with author).

164. The 1987 MLAC Report on the Legal Needs of the Poor found that "[al severe housing crisis faces low-income families in all regions of the state. Legal services attorneys, virtually without exception, rate housing problems as the principal legal problem for low-income clients." MLAC PLAN FOR ACTION, supra note 1, at I23. The assistant clerk magistrate of Boston Housing Court, referring to the poverty of tenants in Housing Court, stated in 1991 that "[t]enants are unemployed, a lot are on welfare and can't even make payments in small amounts." Linda Matchan, Eviction Day Brings a Docket of Anguish, Boston GLOBE, Jan. I1, I991, at I9. With respect to the race, ethnicity and gender of the poor, the 1994 Annual Report of Greater Boston Legal Services (GBLS) reports that 59\% of the GBLS clients served in 1994 were African-American, Hispanic/Latino, or Asian; $70 \%$ of the clients were women. Greater Boston Legal Services, 1994 ANnual Report 10 (1995) [hereinafter GBLS 1994 ANNUAL RePORT]. One reporter described Boston Housing Court as a place where "[w]hites, blacks, Hispanics and Asians sit in common confusion, the thread binding them temporarily together a thin filament of fear that today they will lose their shelter." Lupo, supra note 162 , at 13. 
disparity between landlords' lawyers and unrepresented tenants drives the course of the hallway negotiations. ${ }^{165}$ The absence of counsel has a marked impact on the outcomes of the cases, with represented tenants faring significantly better than unrepresented tenants at each stage of the proceedings. ${ }^{166}$

A recent study of eviction cases in New Haven, Connecticut similarly reports that most landlords are represented, while most tenants appear without counsel. ${ }^{167}$ Tenants often are "extremely poor members of minority groups and women."168 Represented tenants fare significantly better than unrepresented tenants. ${ }^{169}$ Most cases settle before trial, with the settlement agreement "entered into by the parties in the halls of the Housing Session before an impending hearing or trial." 170

The disparity in representation rates has been reported in other housing courts across the country as well. ${ }^{171}$ In each such jurisdiction, landlords' lawyers have incentive to achieve results expeditiously. Impermissible attorney behavior therefore can be expected to occur frequently, depriving tenants of their rights. ${ }^{172}$ The regular occurrence of

165. See Fox, supra note 14 , at $85,98-109$.

166. See Engler \& Bloomgarden, supra note 163, at 5. According to one Housing Court Judge, "[t]he laws regulating landlords and tenants in Massachusetts are technical and complex and often traps for the unwary." Associate Justice Jeffrey Winik, Remarks from the Bench (Nov. 30, 1995).

167. See Steven Gunn, Note, Eviction Defense for Poor Tenants: Costly Compassion or Justice Served?, 13 YALE L \& POL'Y REv. 385 (1995) (comparing contested eviction cases involving unrepresented tenants to cases involving tenants represented by legal services attorneys). In a random sample of 150 eviction cases from 1993 and 1994, "seventy-three percent of the landlords were represented by counsel, while eighty-three percent of the tenants were not." Id. at 411 .

168. Id. at 393 (describing the tenants represented by legal services lawyers). Poor families in New Haven disproportionately are members of racial and ethnic minorities. See id. at 393 n.39. Female heads of households suffer the highest rate of poverty. See id. at 393 n. 40 .

169. See id. at $\mathbf{4 1 3}$ (noting that tenants represented by legal services lawyers "were more than three times as likely to avoid eviction as were unrepresented tenants").

170. Id. at 427.

171. See, e.g., JusTICE EvicTED, supra note 119, at 38-42 (reporting findings from a survey of lawyers from 73 legal services offices in 29 states revealing that in roughly two-thirds of the states, fewer than $10 \%$ of tenants were represented); Anthony J. Fusco, Jr. et al., Chicago's Eviction Court: A Tenant's Court of No Resort, 17 URB. L. ANN. 93, 114-16 (1979) (noting a study of Chicago's Eviction Court covering 1976 through 1978 estimating that landlords were represented in $81.3 \%$ of the cases, while tenants were represented in $7.1 \%$ of the cases).

A study of Baltimore's Rent Court presents a twist on this scenario. There, representation by counsel is rare for both tenants (3.7\%) and landlords (2.5\%). See Bezdek, supra note 14, at 562 . However, "[l]andlords get the lion's share of non-attorney assistance. Ordinarily, they are represented in rent court by an agent who, in the great majority of cases, is a 'repeat player' possessing the specialized legal knowledge needed to operate effectively in the forum." Id. at 562 63. Given the absence of counsel, violations of Rule 4.3, which became effective in Maryland with the adoption of the Model Rules in 1987, would not be the issue. Whether the court is ignoring, if not permitting, the unauthorized practice of law is a separate ethical issue. See MODEL RULES of Professional Conduct Rule 5.5 (1983).

172. This result is likely even in jurisdictions where tenants possess fewer rights than do tenants in New York City or Massachusetts. For example, issues such as whether the landlord must make repairs, whether the tenant is entitled to an abatement, whether rent allegedly owed is the correct 
litigation pitting landlords' lawyers against unrepresented, poor tenants creates a setting ripe for the same kinds of misconduct observed in the New York Courts.

\section{Consumer Cases}

Consumer litigation, such as debt collection claims, also encourages plaintiffs' attorneys to give impermissible advice to pro se defendants. One judge's description, over twenty years ago, of a D.C. court handling consumer cases could also apply today: "the court ... is primarily the court of the skilled lawyer representing large debt collection companies, credit stores, corporate defendants and insurance companies. The pro se party is at a definite disadvantage when he appears in court." 173 These court actions are filed routinely in lower-level courts dominated by creditors and their lawyers appearing against unrepresented individuals. ${ }^{174}$ "In the vast majority of transactions in every consumer sales or loan contract ... one party is unrepresented." ${ }^{\prime 175}$ Few of

amount, whether the landlord followed the required procedures before commencing the proceeding, or even how quickly the tenant must pay, move, or take certain action will be influenced by the negotiation process.

173. Center for Auto Safety, Little lnuustices: Small Claims Courts and the AMERICAN CONSUMER 98 (1972) [hereinafter LitTle 1NJustices]; see also Hillard M. Sterling \& Philip G. Schrag, Default Judgments Against Consumers: Has the System Failed?, 67 DENV. U. L REv. 357, 360 (1990) (reporting findings of study in Small Claims Court in the District of Columbia). The small claims venue does not necessarily alleviate the disadvantaged position of pro se parties. See LitTlE INJUSTICES, supra, at 128 ("Justice is a running dialogue between judges and creditors' attorneys.") (quoting Eric Sevareid, Justice in America (CBS television broadcast, Apr. 1971)) (internal quotations omitted).

Some reformers have called for the exclusion of businesses and collection agencies from small claims court; others have suggested that the exclusion would only exacerbate the problems facing consumers. See, e.g., LitTLE InJustices, supra, at 129 ("One single, strong argument exists for permitting businesses to use the [small claims] courts. In most instances of debt collection claims the businesses concerned are going to attempt to get their money in one way or another. Using a higher court or the services of professional collection agencies may be more expensive for them, but it can also be more costly in both money and harassment for the defendant."); JOHN C. RUHNKA ET AL., Small Claims Courts: A National Examination 45 (1978) ("If colleetion agencies are denied access to small claims court, it is probable that at least some of those claims would be filed in formal civil court... [where] it was virtually impossible for an individual to defend... without an attorney.").

A study of California's Small Claims Courts, which exclude attorneys, catalogues widespread persecution faced by consuners even in the absence of attomeys. See generally Beatrice A. Moulton, Note, The Persecution and Intimidation of the Low-Income Litigant as Performed by the Small Claims Court in California, 21 Stan. L. REv. 1657 (1969).

174. Attorneys dominate the small claims courts in Massachusetts, and nearly $90 \%$ of the cases entered are collection matters. Small Claims Court Abuse By Attorneys 10 (1994) (unpublished manuscript, on file with author). In the District of Columbia, "[a]bout $80 \%$ of the cases in the Small Claims Court are against individual defendants, and about $80 \%$ of those defendants are consumers." Sterling \& Schrag, supra note 173, at 360. Statistics from the Small Claims Court in Washington, D.C. indicate that in $89 \%$ of the cases an attorney appears for the plaintiff, but in less than $4 \%$ is the defendant represented. See LitTLE InJustices, supra note 173, at 98.

175. Abel, supra note 4, at 681 . 
the low- and moderate-income parties unrepresented at the time of the transaction will be able to obtain counsel should court action on the contract ensue..$^{176}$

Each stage of the debt collection process is ripe for attorney misconduct. For instance, the $\mathrm{ABA}$ has ruled that debt collection letters which have the effect of telling the recipient to "pay up or else" constitute impermissible advice-giving since they constitute advice as to the course of conduct the recipient should pursue. ${ }^{177}$ Such impermissible debt collection letters have given rise to numerous disciplinary proceedings against lawyers. ${ }^{178}$

Most collection cases result in a default judgment against the typically unrepresented debtor. David Caplovitz's classic study of consumer cases reported a default rate of over ninety percent in the New York, Chicago and Detroit courts. ${ }^{179}$ A subsequent study from Washington, D.C. yielded a default rate of seventy-four percent. ${ }^{180}$ Over ninety percent of collection cases filed in Sinall Claims Court in the Boston Municipal Court result in default judgments as well. ${ }^{181}$

While the high default rate might suggest that attorneys are not giving advice in this context because they have no contact with debtors, a closer examination belies this conclusion. Caplovitz found that two of the most common explanations given by debtors who received a summons but failed to go to court were that the debtor "[t]ried to settle and thought court action was discontinued," and that the debtor was

176. Consumer cases rank among the highest type of unmet legal needs of low- and moderateincome households. See, e.g., RoY W. ReEse \& Carolyn A. Eldred, Legal NeEdS Among LOW-INCOME AND MODERATE-INCOME HOUSEHOLDS: SUMMARY OF FINDINGS FROM THE Comprehensive Legal NeEds Study 10 (1994). In light of the prevalence of unmet legal needs in consumer cases, a Massachusetts study urged legal services offices to review their priorities with respect to consumer cases. See MLAC PLAN FOR Action, supra note 1, at 125-26.

177. See supra note 28 and accompanying text (discussing Informal Opinions 734 and 1034); supra notes 69-75 and accompanying text (recognizing that more leeway is appropriate for a letter or notice that is a prerequisite for litigation, but that attorneys still must not, beyond accomplishing the legal requirements, give advice, overreach or mislead).

178. See, e.g., State v. Ziegler, 538 P.2d 643, 644 (Kan. 1975) (upholding indefinite suspension where misconduct included sending debt collection letters with statements such as "OH! THE JOY OF BEING SUED!! How do you explain to the neighbors and the kids when the Sheriff's car pulls up front and an officer hands you the summons?... You owe $\$$ PAY ME NOW!!!").

179. David Caplovitz, Consumers in Trouble: A Study of Debtors in Default (1974). Caplovitz's study entailed interviews with 1,038 consumers who had been sued in those three cities. Default judgments were entered in all but eight to nine percent in Chicago, nine to ten percent in Detroit, and seven to eight percent in New York City. See id. at 8-9, 215-21.

180. See Sterling \& Schrag, supra note 173, at 361 . The study consisted of a random sample of 287 suits filed against consumers in Small Claims Court in 1988, followed by interviews with 15 of the defaulting debtors. See id. at 361-62.

181. See Small Claims Court Abuse By Attomeys, supra note 174, at 10; see also LITTLE INJUSTICES, supra note 173, at 98 (placing the figure at over $93 \%$, with 1,268 default judgments entered in the Boston Municipal Court during the month of December, 1971, and only 83 contested cases heard). 
"[a]dvised not to go to court by plaintiff's attorney or own attorney."182 Advice by the plaintiff's attorney not to go to court is the clearest instance of impermissible advice-giving. Where the debtor "tried to settle" with an attorney, and the negotiations left the debtor with the impression that he did not have to go to court, the negotiations likely included impermissible advice-giving as well.

The subsequent study of similar cases in Washington, D.C. both corroborated Caplovitz's findings and demonstrated that the findings were particular neither to the courts he examined nor to the time period of his study. One of the fifteen debtors interviewed in the more recent Washimgton, D.C. study defaulted because the creditor's lawyer, identified by name by the debtor, advised her not to go to court. ${ }^{183}$ Four of the other fifteen defendants interviewed defaulted because unidentified einployees of the same creditor advised the defendant not to go to court. ${ }^{184}$ Most of the debtors interviewed were women, and all but two were black. ${ }^{185}$ None had lawyers. ${ }^{186}$

Even when debtors appear in court, trials rarely occur. Plaintiffs' attorneys routinely continue the cases to a later court date, at which time the debtor may default. ${ }^{187}$ Debtors who do not default are pressured into settling their cases without trial. Caplovitz describes the typical dynamic in court:

When the debtor does appear for a trial, he is usually summoned to the bench by the judge, who is anxious to clear his calendar, and is told to go out into the hall and work out a settlement with the plaintiff's lawyer. In this fashion, even debtors with valid defenses are pressured to make some payment. ${ }^{188}$

182. Caplovitz, supra note 179, at 205. Many debtors did not even receive the summons. Only $54 \%$ of the debtors in New York City reported receiving the summons. The figure rose to $71 \%$ in Chicago and $84 \%$ in Detroit. See id. at 194-95.

183. See Sterling \& Schrag, supra note 173, at 371-72.

184. See id. at 370-72. If the employees were lawyers, or acting on the advice of their lawyers, these defaults might also provide examples of misconduct. See id.

185. See id. at 364.

186. See id. at 386.

187. See Small Claims Abuse By Attomeys, supra note 174, at 11-12. Anticipating a high default rate, creditors' cases typically are covered by an attomey alone, without the creditor in court, and therefore are not ready for trial. See id. at 10-11. Attomeys leave quickly after the calendar call to insure that defendants who arrive late must file a motion to vacate the default judgment-and return on a second day. See id. at 11. In the rare case in which the defendant appears, the creditor's attomey attempts to continue the case "to see if both parties can try and settle the matter." Id. at 1112. This process forces the defendant to come to court a second day, and increases the chance of debtor default.

188. Caplovitz, supra note 179, at 218-19. Caplovitz found that none of the $332 \mathrm{New}$ York defendants, only seven of the 312 Chicago defendants, and at most 11 of the 396 Detroit defendants had gone to trial. See id. at 216-20. Caplovitz recounts an anecdote from Professor Schrag describing a case in which a debtor was contesting the quality of waterproofing work by the plaintiff. The debtor had been advised by the Department of Consumer Affairs to obtain a continuance, and 
In the more recent Washington, D.C. study, none of the 287 files examined resulted in a trial. In the overwhelming majority of the twentytwo percent of cases in which the defendant did appear in court, the defendant consented to meet the plaintiff's demands. ${ }^{189}$

A study of Small Claims Courts in Boston and Cambridge from the early 1970s similarly found that judges encouraged "unrepresented litigant[s] to go outside and attempt a 'settlement' with the attorney representing the other side." 190 The report observes that

anyone who has seen attorneys in action, especially those lawyers who make a specialty of debt collection, knows the variety of tricks of the trade that can be used to victimize citizen-litigants. The Mutt-and-Jeff routine, second-nature to this type of attorney, is one of the more innocuous ones: the attorney waxes friendly at first ... then, when he has his opponent sufficiently off balance, he switches suddenly to a hard-driving, menacing attack, rattling off technical terms, citations, leading questions, and lightly veiled threats. ${ }^{191}$

Over twenty years later, when defendants appear in Small Claims Court in Boston, most cases still settle with the defendant agreeing to a payment schedule. ${ }^{192}$

Once the court enters a judgment against the debtor-a likely result given the high default rate and circumstances surrounding the settlements-the plaintiff-creditor proceeds to the enforcement stage of the case, known in Massachusetts as Supplementary Process. ${ }^{193}$ According to one assistant clerk-magistrate of the Small Claims Court in Boston, some attorneys "corner" the debtor before the debtor even enters the courtroom, preying on the debtor's emotions and knowing "that the debtor will agree to anything not to see the Judge. The attorney will threaten jail, loss of home, or attachment of wages to the bewildered and

not to settle under any circumstances, so that the agency could assist in filing a complaint against the creditor. The judge urged the parties to go into the hallway with the plaintiff's lawyer and reach a settlement. The creditor yielded to the pressure, and agreed not only to pay $\$ 100$ of the $\$ 200$, but to withdraw from government agencies any complaints against the company. See id. at 219 n.29.

189. See id.; see also Sterling \& Schrag, supra note 173, at 387 . Although the Washington, D.C. study did not describe the process of settlement, the fact that every "contested" case resulted in a complete capitulation by the debtor raises concerns about the tactics that the collection attorneys use. The interviewers concluded that 11 of the 15 defendants had potential defenses to the creditor's claims, but nonetheless defaulted. See id. at 375-86. Many of the debtors appearing in court presumably had potential defenses as well.

190. LITTLE INJUSTICES, supra note 173 , at 110.

191. Id.

192. See Small Claims Court Abuse By Attorneys, supra note 174, at 10; see also MAss. TRIAL CT. R., Small Claims STandards 5:03 ("Settlements should be encouraged by the small claims assistant clerk and by the Judge.").

193. See Mass. Gen. Laws ANn. ch. 224, § 14 (West 1985 \& Supp. 1996). 
helpless debtor."194 Through intimidation, attorneys obtain an "agreed" payment schedule that includes the constable fees as well. ${ }^{195}$ The abuses by attorneys, constables, and sheriffs were so widespread that the court was compelled to post signs in the hallways instructing debtors to proceed directly into the courtroom. ${ }^{196}$

At each stage of collection cases, lawyers negotiate with unrepresented debtors. The available studies present specific examples of impermissible advice-giving and describe systemic attorney misconduct in the course of the negotiations. There is ample reason to believe that impermissible advice-giving is rampant in consumer cases, not only once the unrepresented litigant appears in court, but in the preceding interactions with the creditor's lawyer as well.

\section{Family Law Cases}

Family law matters, including divorce and child custody, also are common settings for attorney misconduct during negotiations between lawyers and unrepresented litigants. In the context of divorce cases, the ABA has issued opinions dealing with improper behavior under DR 7 104(A)(2) and its predecessor, Canon 9.197 As with housing and consumer cases, since the negotiations are unmonitored and unrecorded, there is little direct evidence of the attorney misconduct. ${ }^{198}$ Powerful circumstantial evidence, however, strongly suggests that misconduct is commonplace.

Family law judges and lawyers regularly acknowledge the "problems" involved when lawyers face unrepresented parties. ${ }^{199}$ Some

194. Small Claims Court Abuse By Attomeys, supra note 174, at 18.

195. See id.

196. See id. at 20.

197. For example, the 1931 ABA opinion establishing the attorney's proper role in settlement involved a divorce action. See ABA Comm. on Professional Ethics and Grievances, Formal Op. 58 (1931); see also supra note 26 and accompanying text. Similarly, the three ABA Informal Opinions discussing the propriety of proposed waivers involved attorneys' communications with unrepresented defendants in divorce proceedings. See ABA Comm. on Ethics and Professional Responsibility, Informal Op. 1269 (1973); ABA Comm. on Ethics and Professional Responsibility, Informal Op. 1255 (1972); ABA Comm. on Ethics and Professional Responsibility, Informal Op. 1140 (1970); see also supra note 32 and accompanying text.

198. Fewer studies and articlcs have captured the misconduct in the family law area, providing less direct evidence than in the housing and cousumer area. The setting generally has been ignored by legal scholarship as well. See Robert H. Mnookin \& Lewis Komhauser, Bargaining in the Shadow of the Law: The Case of Divorce, 88 YALE L.J. 950,959 n.36 (1979).

199. See, e.g., Ralph C. Cavanaugh \& Deborah L. Rhode, Project, The Unauthorized Practice of Law and Pro Se Divorce: An Empirical Analysis, 86 YALE L.J. 104, 150 (1976) (noting that DR 7-104 and EC 7-18 "severely constrict the extent to which attorneys may deal directly with unrepresented 'adversaries," and stating that the "problem is widely recognized in the literature"); Flaschner Judicial Institute, Report of the Massachusetts Probate and Family Court Bench/Bar Conference, LAw. J., Jan. 1996, at 1, 6 (special supplement) [hereinafter Mass. Bench/Bar Conf.]; Maureen McKnight, Dealing with the Unrepresented Opponent, Address at the Oregon Family Law Spring 1996 Conference (1996) (manuscript on file with author). 
attorneys describe the "pro se problem" as one that makes the system unfair for represented parties. ${ }^{200}$ Counsel to the represented party often see the unrepresented party as taking up too much time, and the court as giving too much latitude and even favorable treatment to the unrepresented party. ${ }^{201}$ However, the "problems" that arise include impermissible advice-giving and overreaching by lawyers.

One Massachusetts Probate and Family Court judge acknowledges "the problem of pro se litigants claiming that the opposing attorneys told them something." get from some of the unrepresented clients is [sic] that [the lawyers] are overbearing, [and are] taking advantage of them because they are unrepresented." 203 In the words of another long-time family law practitioner, "borderline negotiations with unrepresented parties [in family law cases] are going on all the time."204 Not surprisingly, an Arizona study

One Massachusetts Family Law Treatise observes that "[a] not uncommon problem for family lawyers is how to deal with opposing parties who are not represented by counsel.... [T] litigant in divorce and other domestic relation cases presents problems for the opposing attorney." 1 Charles P. Kindregan, JR. \& Monroe L. Inker, Mass. Practice § 2.12, at 71 (2d ed. 1996). After noting that the lawyer will have to negotiate with the pro se litigant, the sole guidance offered by the treatise is that the lawyer "must take great care not to give him advice about legal rights or liabilities." Id.

The American Academy of Matrimonial Lawyers Standards of Conduct provides that "[a]n attomey should not advise an unrepresented party." Srandards of Conduct 2.21 (Am. Academy of Matrimonial Lawyers 1991). The comment, in its entirety, reads:

Once it becomes apparent that the opposing party intends to proceed without a lawyer, the attorney should, at the earliest opportunity, inform the opposing party in writing as follows:

1. I am your spouse's lawyer.

2. I do not and will not represent you.

3. I will at all times look out for your spouse's interests, not yours.

4. Any statements I make to you about this case should be taken by you as negotiation or arguinent on behalf of your spouse and not as advice to you as to your best interest.

5. I urge you to obtain your own lawyer.

Id. Standard $2.21 \mathrm{cmt}$. (footnotes omitted).

200. See, e.g., Bruce D. Sales et al., Is Self-Representation a Reasonable Alternative to Attorney Representation in Divorce Cases?, 37 ST. LouIs U. L.J. 553, 558 (1993) ("An issue ... is whether judicial assistance to self-represented litigants in any way biases the outcoine in their favor when the opposing parties are represented by attorneys."). At the 1995 Massachusetts Bench/Bar Conference, attorneys complained that pro se litigants took up too inuch time and were not required to follow the rules. See Mass. Bench/Bar Conf., supra note 199, at 7, 11.

201. See id.

202. Mass. Bench/Bar Conf., supra note 199, at 6 (comments of Judge Eileen M. Shaevel).

203. Id. Another judge urged his fellow judges to appreciate the problems lawyers encounter when there is a pro se litigant on the other side, especially in communications, "[a]nd the lawyers are concerned that they're going to be accused of being overbearing or representing the other side." Id. at 12 .

204. Electronic mail from Joan Meier, Professor of Clinical Law \& Director of Domestic Violence Advocacy Project, George Washington University, to the author (Jan. 15, 1996) (on file with author). Professor Meier reported one example in which a student-attorney, in the course of hallway negotiations, told an unrepresented party who was resisting child support, that "if we go in there and ask for child support we'll get it, and we're entitled to it." Id. The student's actions were no less aggressive than the average family law attorney Professor Meier has observed. In child 
found that pro se litigants who faced attorneys were less likely to want to represent themselves again than those who faced other pro se litigants. ${ }^{205}$

An examination of the family law courts, the litigants, and the lawyers reveals why the "pro se problem" lends itself to impermissible advice-giving by the attorneys. Most family law cases settle with minimal interventiou of the court. ${ }^{206}$ The settlement rate is over nimety percent, ${ }^{207}$ with one estimate placing the Massachusetts settlement rate as high as ninety-seven percent. ${ }^{208}$ The courts typically act only as a "rubber stamp" for private agreements. ${ }^{209}$ One Connecticut study found that the average amount of time for a court hearing on an uncontested divorce was four minutes. ${ }^{210}$

Though they provide only minimal oversight, the courts often pressure litigants to settle. ${ }^{211}$ Judges in Massachusetts soinetimes "convey pressure to settle because they are feeling the pressure of the backlog and the press of new cases."212 Another study of Massachusetts courts

support cases, lawyers for the plaintiff "basically TELL the [unrepresented defendant] what he needs to do." Electronic mail from Joan Meier, Professor of Clinical Law \& Director of Domestic Violence Advocacy Project, George Washington University, to the author (Jun. 14, 1996) (on file with author).

205. See Sales et al., supra note 200 , at 593 ("[O]nly $36 \%$ of self-represented respondents who faced attorneys would represent themselves again, as compared to $70 \%$ of those who faced selfrepresented petitioners.").

206. See Mnookin \& Kornhauser, supra note 198, at 951 ("[T]he overwhelming majority of divorcing couples resolve distributional questions concerning marital property, alimony, child support and custody without bringing any contested issue to court for adjudication."). Lawyers in one Connecticut study identified negotiation as one of their most important functions in their divorce cases. See Cavanaugh \& Rhode, supra note 199, at 141-43.

207. See Mnookin \& Kornhauser, supra note 198, at 951 n.3 ("[O]nly a very small percentage of divorces-probably less than 10\%-involve disputes that are contested in court."); see also SUPREME Judicial Court, Commonwealth of Massachusetts, Report of the Gender Bias Study of THE Supreme Judicial Court 74 n.20 (1989) [hereinafter Mass. Gender Bias Study] ("[V]ery few cases are in fact litigated."); Eleanor E Maccoby \& Robert H. MNookin, Dividing The CHILD 137 (1992) (noting that only $1.5 \%$ of a sample of 933 California custody and visitation cases were decided by a judge); Richard Necly, The Primary Caretaker Parent Rule: Child Custody and the Dynamics of Greed, 3 YALE L. \& PoL'y REv. 168, 173 n.11 (1984) ("Over 90 percent of divorces are uncontested. This means that the granting of the divorce is pro forma and routine, with all the important decisions made out of court-usually in law office negotiations.").

208. See Mass. Bench/Bar Conf., supra note 199, at 6.

209. Mnookin \& Kornhauser, supra note 198, at 956; see also Neely, supra note 207, at 177 ("Divorce decrees are typically drafted for the parties after compromises reached through private negotiation. These compromises are then approved by a judge, who generally gives them only the most perfuuctory sort of review.").

210. See Cavanaugh \& Rhode, supra note 199, at 129 (noting that cases in which no financial awards were made usually required less than three minutes, while cases featuring such awards typically lasted about five and a half minutes).

211. In Massachusetts, for example, family matters are referred to mediators, called family service officers. Family service officers report pressure from judges to settle cases, and indicate that they believe their job effectiveness is evaluated based on how many cases they settle. See Andree G. Gagnon, Ending Mandatory Divorce Mediation for Battered Women, 15 HARv. WOMEN's L.J. 272, 281 (1992).

212. MAss. Gender Bias Study, supra note 207, at 24. 
found that "in some courts cases are overbooked in the hope that they will be settled."'213

Settlements are often the result of negotiations between a lawyer and a pro se litigant. In over thirty-five percent of the divorce cases filed in Maricopa County, Arizona in 1990, one side was pro se, while the other was represented by an attorney. ${ }^{214}$ Forty-four percent of the family law filings in Oregon involved only one represented party. ${ }^{215}$ One Massachusetts judge estimated that thirty to thirty-five percent of family law cases involve a pro se litigant against a lawyer. ${ }^{216}$ The numbers of pro se litigants in family law cases have surged nationwide: reports from Arizona, ${ }^{217}$ California, ${ }^{218}$ Massachusetts, ${ }^{219}$ Oregon, ${ }^{220}$ and Washmgton ${ }^{221}$ indicate that between sixty-two and eighty-nine percent of cases involve at least one pro se litigant.

Self-representing litigants face numerous disadvantages that may affect their ability to negotiate effectively. Pro se litigants in family law cases often are economically and emotionally vulnerable. An Arizona study found that litigants from lower-income households were much more likely to self-represent than those litigants with higher household incomes. ${ }^{222}$ Family law matters are among the top category of legal

213. Mass. Bench/Bar Conf., supra note 199, at 7.

214. See Sales et al., supra note 200, at 571 n.82.

215. Letter from Kingsley W. Click, State Court Administrator, Oregon Judicial Department, to Maureen H. McKnight, Attorney at Law, Oregon Legal Services Corporation 2 (Nov. 8, 1995) (on file with author) [hereinafter Letter from Kingsley W. Click].

216. See Mass. Bench/Bar Conf., supra note 199, at 11 ("probabiy close to 60 percent of our cases now... have at least one side pro se and maybe 25 to 30 two sides pro se") (quoting a judge from eastern Massachusetts) (internal quotations omitted); see also Cavanaugh \& Rhode, supra note 199 , at 129 (noting that $56 \%$ of the defendants in lawyer-initiated eases studied in Connecticut did not retain counsel); Caroline Kearney, Pedagogy in a Poor People's Court: The First Year of a Child Support Clinic, 19 N.M. L. REv. 175, 181 (1989) (noting that in the Brooklyn Family Court, the respondents were unrepresented in $70 \%$ of the child support eases handled by one law school clinic).

217. See, e.g., Deborah L. Rhode, The Delivery of Legal Services by Non-Lawyers, 4 GEo. J. LEGAL ETHICs 209, 214-15 (1990) (noting an Arizona study finding that pro se filings for a sample of divorce cases increased from $24 \%$ to $47 \%$ between 1980 and 1985); Sales et al., supra note 200, at $570-71 \&$ n.82 (noting that by 1990 , in $88.2 \%$ of the divorce cases filed in Maricopa County, Arizona, at least one of the litigants was self-represented).

218. See, e.g., Rliode, supra note 217, at 214-15 (noting that the proportion of pro se filings in surveyed California counties grew from $39 \%$ to $62 \%$ of family law cases during the 1980 s).

219. See, e.g., Daniel Golden, Probate Plaintiffs At Risk Without Lawyers, Boston Globe, Nov. 27, 1995, at 1 ("[ [] $]$ udges in Boston and Worcester family courts estimate that as many as two-thirds of the people appearing before them now aro pro se [while] the number of people representing themselves is surging nationwide as well.").

220. See Letter from Kingsley W. Click, supra note 215 , at 2 (revealing that $89 \%$ of the family cases in Oregon involve at least one pro se party).

221. See Erin M. Moore, The Cost of Divorce: Pro Se Litigants Flood Family Law Courts, DE Novo, May 1995, at 1 (reporting that $77 \%$ of all family law cases in Washington involve one unrepresented litigant).

222. See Sales et al., supra note 200 , at 561 (rcporting that litigants with household incomes under $\$ 30,000$ are mucli more likcly to self-represent than families with higher incomes). Professor 
needs of low-income and moderate-income households. ${ }^{23}$ Because women typically are poorer than men, "[f]amily law experts believe that women are unrepresented more often than men and that the outcomes they obtain suffer as a result.."224 A Massachusetts study on gender bias in the courts indicates that many women cannot obtain the assistance they need, particularly in the crucial first days and months after separation. The report suggests that women suffer more from lack of counsel than do men for three reasons: "1) court clerks are often hostile to pro se litigants; 2) there are too few free legal services available for the poorest litigants; and 3) there is too little legal help available to moderate-income women ...."225 "[Single] [w]omen maintaining families are far more likely to be unemployed than husbands or wives, their average (median) family income is less than half that of married couples, and they are five times as likely to be in poverty." 226 Chief Justice Neely of the West Virginia Supreme Court of Appeals observes that "in-court rules on out-of-court bargaining" are often "informed more by wishful thinking than by the facts of life: Many people (especially men) begin with a political conviction that women ought to be equal to men economically, from which they leap to the insupportable conclusion that women are equal to men

Rhode's survey revealed that the major reasons for not obtaining counsel were cost and lack of knowledge about how to obtain assistance. See Rhode, supra note 217 , at 229 . The Arizona study similarly found that litigants frequently listed as reasons for self-representing not only that they could not afford an attorney, but that they did not want to spend the money on an attorney. See Sales et al., supra note 200, at 590. Perhaps unrelated to cost, a sizeable portion of self-representing litigants felt the case was simple and they could handle it on their own. See id.

Sales, Beck, and Haan acknowledge that the poorer, less educated part of the population may have been underrepresented in the Arizona study. The authors collected data by conducting telephone interviews after litigants filled out consent-to-be-interviewed forms. The authors speculated that poorer, less-educated litigants may not have had telephones, and therefore may have been less likely to complete the forms. See id. at 593 .

223. See, e.g., REESE \& ELDRED, supra note 176, at 3 (defining low-income housebolds as "those with an annual household income at 125 percent of the Federal poverty level or below" and moderate-income households as "those with incomes above 125 percent of the poverty level but below $\$ 60,000 ")$. The Massachusetts study of unmet legal needs found that family law problems were by far the most prevalent recognized legal need encountered by low-income households: farnily law problems were encountered by $29.2 \%$ of low-income households. See MLAC PLAN FOR ACTION, supra note 1, at 3. Family law cases accounted for roughly a third of all cases handled by legal services offices in 1994, the highest such category. See id. at 5.

224. MASs. GENDER BIAS STUdy, supra note 207, at 20; see also Kearney, supra note 216, at 176 ("One of the frequently cited barriers to the establishment and collection of support orders is the inability of large numbers of women to afford counsel.") (citing REPORT OF THE NEW YORK TASK FORCE ON WOMEN IN THE COURTS 137-38 (1986), reprinted in 15 FORDIIAM URB. L.J. 1 (1986); Lenore J. Weitzman, The Divorce Revolution 287-92 (1985)) (footnotes omitted).

225. MASS. GENDER Bias Study, supra note 207, at 20. The clerks' hostility to pro se litigants will disproportionately affect women, since women are unrepresented more often than men. See supra note 224 and accompanying text.

226. Neely, supra note 207, at 179 n.16 (quoting Bureau of LABor Statistics, U.S. Dep'T of LABOR, WOMEN AT WORK: A Chartbook 26 (1983)) (internal quotations omitted). 
economically."227 Moreover, "matrimonial matters ... 'are unequaled in stress and emotion," leaving many family law litigants emotionally, as well as economically, vulnerable. ${ }^{228}$

Lawyers who use unfair tactics in matrimonial negotiations may easily exploit the vulnerability of family law litigants, particularly of women. The process of negotiation, in which "parties and their representatives ... frequently threaten and bluff," is inherently a dangerous setting for parties of unequal power. ${ }^{229}$ Commentators describe the negotiation tactic of "custody blackmail," in which "divorcing husbands routinely and successfully use the threat of a custody fight to reduce or eliminate alimony and child support obligations."230 Women are exposed to "extortionate bargaining at the hands of their husbands,"231 and are more likely than men to bargain away property to get their preferred custody or visitation arrangement. ${ }^{232}$ The vulnerability of many female litigants, particularly of women who are victims of domestic abuse, has led to growing criticism of the use of mandatory mediation in family law cases. ${ }^{233}$ According to judges and other legal observers of

227. Id. at $178-79$.

228. Jan Hoffman, New York's Chief Judge Imposes Strict Rules for Divorce Lawyers, N.Y. TIMES, Aug. 17, 1993, at A1 (quoting Chief Judge Judith S. Kaye of the New York Court of Appeals); see also STANDARDS of Conduct Preliminary Statement (Am. Academy of Matrimonial Lawyers 1991) ("Family disputes occur in a volatile and emotional atmosphere."); Trina Grillo, The Mediation Alternative: Process Dangers for Women, 100 YALE LJ. 1545, 1572 (1991) ("[F]amily conflicts ... often involve a combination of emotional and legal complaints.").

229. Mnookin \& Kornhauser, supra note 198, at 973.

230. Jana B. Singer \& William L. Reynolds, A Dissent on Joint Custody, 47 MD. L. Rev. 497, 503 (1988) (noting that the success of the "custody blackmail" tactic has been identified as a major cause of impoverishment of divorced women and their children); see also WEITZMAN, supra note 224, at $310-12$; Neely, supra note 207 , at 168-69.

231. Neely, supra note 207, at 171; see also Deborah L. Rhode, Speaking of Sex (forthcoming 1997) ("Surveyed attomeys estimate that in over a fifth of divorce cases, one parent, almost always the mother, experiences pressure to make financial concessions in order to prevent custody battles.") (citing Scott Altman, Lurking in the Shadow, 68 S. CAL. L. REv. 493, 497-504 (1995)); Nancy D. Polikoff, Why Are Mothers Losing: A Brief Analysis of Criteria Used in Child Custody Determinations, 14 Women's RTs L. ReP. 175, 182-83 (1992) ("[C]ustody is often used as a bargaining tool to obtain more advantageous financial settlements, [and] the primary caretaker's bond with the children is likely to be so strong that s/he would in fact bargain away economic benefits in order to retain custody.") (citing Garska v. McCoy, 278 S.E.2d 357, 360, 362 (W. Va. 1981)). But see MACCOBY \& MNoOKIN, supra note 207, at 154-59 (1992) (questioning how widespread the practice of custody blackmail is, based on California study).

232. See MASS. GENDER BIAs STUdy, supra note 207, at 25.

233. See, e.g., Committee for Gender Equality of the Mass. Supreme Judicial Court, Achieving Equity: Recommendations for Dispute Intervention Practice in the Probate \& FAMILy Court (1995) [hereinafter ACHIEving EQuiTy]; Mass. Gender Bias STudy, supra note 207, at 23-27; Penelope Eileen Bryan, Reclaiming Professionalism: The Lawyer's Role in Divorce Mediation, 28 FAM. L.Q. 177, 189 n.8 (1994); Gagnon, supra note 211, at 281; Grillo, supra note 228 , at $1549-50$.

Many divorcing couples, however, have reported that they were pleased with their mediation experiences and are more satisfied with their divorce outcomes than persons using the adversary system. See id. at 1548-49 \& nn. 7-8; see also Becky Hoover Hermstein, Women and Mediation: A 
the Massachusetts Probate and Family Courts, "[w]ithout attorneys, [unrepresented female litigants] run more risk of losing their children, paying excessive support, being pressured into an unfair settlement-or even making themselves vulnerable to batterers."234

While the pro se litigants often are economically and emotionally vulnerable, divorce lawyers often resort to "unfair and unscrupulous practices" in divorce litigation, a practice that has garnered the label "bombing." for resorting to tactics that the majority dislikes, but in the current moral climate nothing succeeds like success."236 The practices of divorce lawyers have contributed to calls for the liberalizing of rules restricting non-attorneys from assisting unrepresented litigants in divorce matters ${ }^{237}$ and to the exclusion of lawyers from divorce mediations in some jurisdictions, such as Califoruia. ${ }^{238}$

Decisions vacating those divorce judgments that have incorporated unfair settlements provide further evidence of attorney misconduct in negotiations between lawyers and unrepresented party opponents. The courts identify misrepresentation, advice-giving, and overreaching of the lawyer as part of the analysis of the validity of agreements, suggesting that the behavior is not uncommon. ${ }^{239}$ For example, one Florida case

Chance to Speak and to Be Heard, 13 Mediation Q. 229 (1996) (defending mediation as a useful forum for women).

234. Golden, supra note 219, at 1.

235. Richard E. Crouch, The Matter of Bombers: Unfair Tactics and the Problem of Defining Unethical Behavior in Divorce Litigation, 20 FAM. L.Q. 413, 413 (1986). Crouch is the former chairman of the Committee on Ethical Practices \& Procedures of the American Bar Association's Section on Family Law. He discusses countless cases of unethical behavior by divorce lawyers in the areas of "Acts Unfair to Third Parties, Children, Etc.," "Unfaimess to Opposing Party," "Fraud upon the Court," and "Unfaimess to Opposing Counsel." Id. at 415-34. This last category includes subcategories of "Dishonesty Generally," "Allowing or Using Perjury," "Unfounded Claims, Groundless, Frivolous and Dilatory Litigation," "Ex Parte Practice," "Otherwise Bypassing Opposing Counsel," "Discovery Abuses," "Tactical Delay and Assuring Nonfinality of Litigation," "Generally Reprehensible Conduct," and "Abusive Conduct Toward Opposing Counsel in the Courtroom."

236. Id. at 415. Recognizing that "zealous representation of individual clients ... is not always appropriate in family matters," and seeking "to provide gnidance to matrimonial lawycrs confronting moral and ethical problems," the American Academy of Matrimonial Lawyers promulgated in 1991 Standards of Conduct entitled "Bounds of Advocacy." Standards of Conduct Preface (American Academy of Matrimonial Lawyers 1991).

237. See Sales et al., supra note 200 , at 556 ("[S]ince lawyers are ethically bound to zealously advocate for their clients in some states, they may be more likely to promote adversarialness, while self-representation may lessen the adversarial nature of dispute resolution.") (footnotes omitted); see also Cavanaugh \& Rhode, supra note 199, at 148 (finding a sizeable number of divorce lawyers in Connecticut describing negotiation as their most important function and phrasing their primary purpose in terms of advocacy rather than equitable adjustment between the parties).

238. See Grillo, supra note 228 , at 1600 . The authority to exclude lawyers from mediation appears in CAL FAM. CODE § 3182(a) (West 1996).

239. See, e.g., Tenneboe v. Tenneboe, 558 So. $2 \mathrm{~d} 470$ (Fla. Dist. Ct. App. 1990) (holding that the final judgment of dissolution of the marriage should have been set aside due to overreaching and misrepresentation on the part of the wife's lawyer). The Florida appellate court cites a long line of 
involved a settleinent executed in the wife's attorney's office, where the husband appeared without counsel. The husband testified that, at the signing of the agreement, he had protested that the alimony and support payments were more than he could handle. According to the husband,

the wife's attorney told him that he could return to court at a future time to have the payinents modified, but according to the husband, the wife's attorney did not tell hin that he would have to show a substantial change in circuinstances or financial ability in order to obtain such reduction. ${ }^{240}$

Although the wife and her attorney denied the husband's version of the conversation, the court concluded that "the advice given by the wife's attorney was, at best, an oversimplification."'241

The attorney's role was central in another Florida case in which the court set aside a judgment that had incorporated a grossly disproportionate settlement agreement prepared by the husband's attorney and executed in the husband's attorney's office. ${ }^{242}$ "While the husband testified that he was of the opinion his attorney was fairly representing both parties, the attorney himself denied it, saying that he represented only the husband."243 The court found that the attorney acted impermissibly in giving advice to the wife who had no independent representation.

The conclusion is inescapable that impermissible advice-giving in family law cases is widespread. ${ }^{244}$ Over-zealous lawyers, operating with

cases overturning marital agreements "upon proper allegations and proof of fraud, misrepresentation, overreaching, or other forms of misconduct expressly recognized by the cases." Id. at 473 .

The scenario of one attorney and two parties has spawned a similar line of cases in Washington. See, e.g., In re Marriage of Matson, 730 P.2d 668 (Wash. 1986) (finding prenuptial agreement invalid where only husband had counsel and wife was asked to sign on eve of wedding); In re Marriage of Foran, 834 P.2d 1081 (Wash. Ct. App. 1992) (affirming decision that a prenuptial agreement was unenforceable because it was patently unfair and the wife did not have a full understanding of the legal consequenees of the contract, and therefore could not voluntarily and intelligently waive her rights).

240. Tenneboe, 558 So. $2 \mathrm{~d}$ at 472.

241. Id. at 474. Similarly, the Supreme Court of Washington determined that a prenuptial agreement was unenforceable in part because the attorney "[undertook] to tell part of the story to an unrepresented party with whom the attorney's client is doing business... [but failed to] take reasonable steps to tell the whole story, not just the self-serving portions of it." Foran, 834 P.2d at 1088.

242. DeMaggio v. DeMaggio, 317 So. 2d 848, 849 (Fla. Dist. Ct. App. 1975).

243. Id. at 850 .

244. The scenario where the parties enter into a "law office settlement," but where only one lawyer is involved, is both common and full of ethical pitfalls. As the court in Foran observed,

In the instant matter, Mr. Pewe found himself in a position that is all too familiar to attomeys who work with prenuptial contracts. The economically disadvantaged party may not only be reluctant to obtain independent legal counsel but also he or she may decline to do so, even after being advised to do so by the attomey for the represented party. It was so in this case. It was so in Matson. 
minimal oversight by the courts, negotiate with unrepresented and vulnerable litigants who are under pressure from the courts to settle. The "pro se problem" should be more properly recognized as an "attorney problem" of rampant misconduct during negotiations.

\section{Beyond Housing, Consumer, and Family Cases}

The potential for attorney misconduct exists whenever attorneys regularly negotiate with unrepresented litigants. The potential for misconduct increases where the cases involve court pressure for settlement, the negotiations are unmonitored, and the litigants are economically and emotionally disadvantaged. Although the prevalence of attorney misconduct in New York City's Housing Court may be extreme, misconduct is all too common in many other settings as well. These disturbing examples reveal widespread misconduct that the legal profession cannot continue to ignore. Part III discusses possible responses to the problem.

\section{III \\ Responses To The Problem}

While the problem of unethical negotiations and impermissible advice-giving is readily identifiable in a number of settings, solutions to the problem are less apparent. This Part identifies and evaluates a number of possible steps for addressing attorney misconduct in settings where unrepresented litigants regularly face lawyers. Possibilities include disciplinary proceedings against offending lawyers, promulgation of specific ethical rules regulating negotiations between lawyers and unrepresented adversaries, increased oversight by court personnel (including judges, their assistants or clerks, and mediators), and expansion of the availability of counsel. While none of these proposed measures alone will solve the problem, each supplies an important component of an overall enforcement strategy.

This discussion is framed by Professor Wilkins' approach to curbing attorney misconduct by utilizing an overall enforcement strategy tailored to a particular context. Wilkins argues that identifying an appropriate enforcement strategy "requires paying careful attention to differences in enforcement contexts." 245 He separates commonly

Foran, 834 P.2d at 1088; see also Tenneboe, 558 So. 2d at 473-75; DeMaggio, 317 So. 2d at 849-50. Where the attomey claims to represent only one party, the potential for impermissible advice-giving is enormous. Where the attomey attempts to represent both parties, the attorney is vulnerable to conflict of interest allegations, and even negligence claims for failure to advise, investigate, or disclose. See, e.g., Klemm v. Superior Court, 142 Cal. Rptr. 509 (Cal. Ct. App. 1977); Ishmael v. Millington, 50 Cal. Rptr. 592 (Cal. Ct. App. 1966).

245. Wilkins, supra note 15, at 804. Reaffirming the importance of context, Professor Wilkins states that " $[t] 0$ the extent that we are to develop an account of lawyer professionalism that has 
discussed enforcement systems into four paradigmatic models: disciplinary controls, liability controls, institutional controls, and legislative controls. ${ }^{246}$ "From the standpoint of achieving optimal levels of compliance... all four regulatory models should be used freely when they are likely to contribute to enforcement objectives."247

Though Wilkins does not discuss the context of interactions between lawyers and unrepresented adversaries, ${ }^{248}$ his matrix for analyzing enforcement strategies is a helpful starting point for this analysis. ${ }^{249}$ The use of disciplinary controls, considered in Parts III.A and III.B, and institutional controls, considered in Parts III.C and III.D, are critical components of the overall enforcement scheme. Legislative controls, such as creating a new administrative agency to investigate and prosecute lawyer misconduct, might be implicated if the profession is unable to curtail the misconduct through the use of institutional and disciplinary controls. ${ }^{250}$ Liability controls are not critical components of an enforcement scheme for improper attorney advice-giving to unrepresented adversaries where the vast majority of those unrepresented adversaries are poor. ${ }^{251}$

meaning in the real world, it inust begin with a detailed study of how these institutions shape and are shaped by the actions of lawyers. Context, therefore, is unavoidable." Wilkins, supra note 16, at 487 .

246. See Wilkins, supra note 15 , at $804-09$. In referring to disciplinary controls, Professor Wilkins inost typically is discussing "the current disciplinary system, in which independent agencies acting under the supervision of state supreme courts investigate and prosecute violations of the rules of professional conduct." Id. at 805 . "Liability controls" refer to the traditional right of injured clients, "and to a limited extent, third parties ... to sue lawyers under a variety of statutory and common law theories." Id. at 806. "Institutional controls" refer to controls inposed by the particular institutions, such as the courts or administrative agencies in which lawyers work. Examples of institutional controls are Rule 11 and regulatory regimes of agencies such as the Securities and Exchange Commission and the Internal Revenue Service. Id. at 807-08. "Legislative controls" would imclude, for example, creation of a new administrative agency that would have the sole responsibility for investigating and prosecuting lawyer misconduct. Id. at 808-09.

247. Id. at 851.

248. Professor Wilkins' article does not discuss this scenario. As noted above, the ethical rules virtually ignore the scenario in which a lawyer interacts with a lay adversary. See supra notes 5-14 and accompanying text.

249. The responses of increased use of disciplinary proceedings and oversight by the court fit squarely within the rubric of disciplinary controls and institutional controls, respectively. The adoption of new rules regnlating negotiations between lawyers and unrepresented adversaries and the expansion of the availability of counsel could implicate disciplinary controls, institutional controls, or legislative controls. As Professor Wilkins recently has acknowledged, however, "these categories are still too general to produce judgments about the proper scope of professional regulation that will be valid for "all aspects of all cases in the category." Wilkins, supra note 16, at 481 .

250. The drawbacks Professor Wilkins identifies would apply with full force. See Wilkins, supra note 15, at 844-47. It is doubtful that "simply substituting politically accountable administrators for judicially supervised disciplinary officials will produce large compliance gains." Id. at 845 . Changing the identity of the disciphnary officials, while not necessarily insignificant, seems less important than the other responses discussed in this Article.

251. Liability controls, the ability of an iujured party to sue the lavyer, are not a viable option for the unrepresented adversary. "Liability controls traditionally have been used almost exclusively by injured clients." Id. at 830 . Even for injured clients, "litigation against lawyer-defendants is 
Part III.A examines the effectiveness of disciplinary proceedings to enforce DR 7-104(A)(2) and Rule 4.3 to curtail impermissible advicegiving. Disciplinary proceedings must address the misconduct of individual lawyers and also send a message to other attorneys, curbing more widespread conduct. As discussed in Part III.B, the effectiveness of the disciplinary controls would be enhanced by additional ethical mles regulating negotiations between lawyers and unrepresented parties. ${ }^{252}$

Part III.C discusses the importance of increased oversight by the courts as a component of the overall strategy. Increased oversight should be designed to reduce the incidence of unmonitored negotiations and the incentive for attorneys to give advice and overreach. A series of proposals discussed in Part III.D could become the components of institutional controls for institutions in which there are a large number of unrepresented litigants.

As discussed in Part III.E below, the only solution that would eliminate impermissible advice-giving is the provision of counsel for the unrepresented litigant forced to negotiate against a lawyer. Depending on its implementation, this response to the problem could implicate what Wilkins categorizes as disciplinary controls, institutional controls, or legislative controls. The legal profession must redouble its efforts to expand the provision of counsel, particularly in settings where attorney misconduct is prevalent. Fiscal and political realities, however, suggest that efforts to provide counsel for all indigent civil litigants will not succeed. Negotiations between lawyers and unrepresented parties will remain common occurrences.

As Wilkins' analysis correctly predicts, no single response is likely to comprise a solution to the ethical problem of impermissible lawyer negotiations with unrepresented parties. Rather, the legal profession must adopt a series of protections, involving disciplinary, institutional, and legislative controls, in response to the problem. Absent the enactment of comprehensive corrective ineasures by the profession, lawyers will continue to take advantage of unrepresented parties through unethical negotiations.

particularly difficult to win." Id. at 831. Unrepresented adversaries would be less successful than injured clients, given the minimal duty owed to the unrepresented adversary and the difficulty of proving causation and damages. But see Sainsbury v. Pennsylvania Greyhound Lines, 183 F.2d 548, 550-51 (4th Cir. 1950) ("The rule is also well established that when a lawyer makes a misrepresentation of law to a layman relief may be afforded, even thougl the layman knows the lawyer represents an antagonistic interest. Any other rule would be unconscionable."); Jeska v. Mulhall, 693 P.2d 1335, 1337-38 (Or. Ct. App. 1985) (declaring misrepresentation of fact by lawyer to lay person actionable).

252. If the rules are to be enforced in the courts, or before a new legislative agency, rather than through existing disciplinary bodies, the rule changes could implicate institutional and legislative controls as well. 


\section{A. Disciplinary Proceedings}

Disciplinary bodies can and should take action against attorneys who violate DR 7-104(A)(2) and Rule 4.3. In Wilkins' terminology, this response involves utilizing disciplinary controls. ${ }^{253}$ Strict enforcement not only would curb the behavior of the attorneys disciplined, but also would send a message to other attorneys, having a more widespread effect on impermissible behavior. Disciplinary bodies may impose a range of public and private sanctions from censure to disbarment. ${ }^{254}$ Even private discipline may send an important inessage to a lawyer who receives it. ${ }^{255}$ Repeated or multiple instances of less serious behavior may nonetheless lead to more serious penalties. Finally, the publication of decisions without the attorney's name, or the imposition of public sanctions, may have a strong deterrent effect on other members of the bar.

Given the nature of the misconduct at issue, disciplinary actions should be initiated by the disciplinary bodies themselves. These disciplinary bodies possess the power to initiate and investigate complaints sua sponte. ${ }^{256}$ These bodies also could send investigators to courts to observe and record behavior. The fact that many observers have recorded inappropriate behavior without disrupting the court suggests that such investigations would not be difficult. As Professor Wilkins has argued, "disciplinary authorities must concentrate more of their limited resources on investigation and prevention."257

An inquiry into potential complaints regarding DR 7-104(A)(2) or Rule 4.3 reveals why the attorney misconduct will proceed unchecked unless complaints are initiated by disciplinary bodies. Currently few, if

253. See Wilkins, supra note 15 , at 805-06.

254. See, e.g., MASS. SUP. JUD. CT. R. 4:01, § 4 ("Discipline of attorneys may be (a) by disbarment or suspension by this court; (b) by public reprimand by the Board; or (c) by admonition by the Bar Counsel."); N.Y. Comp. Codes, R., \& Regs. tit. 22, \& 605.14(a)(4) (1990) (New York State's rules governing Manhattan and the Bronx, listing permissible sanctions as including reprimand, referral to the court with a recommendation for censure, suspension, or disbarment, among others).

255. The heated litigation in Attorney $Q$ involved a private reprimand. Attomey $Q$ v. Mississippi State Bar, 587 So. 2d 228, 229 (Miss. 1991).

256. See, e.g., MAss. Sup. Jud. CT. R. 4.01 § 5(3) ("The Board of Bar Overseers. (a) may consider and investigate the conduct of any attomey within this court's jurisdiction either on its own motion or upon complaint by any person") (second emphasis added); N.Y. CoMP. CoDEs, R., \& REGS. tit. 22, § 605.6(a) (1990) ("Initiation of Investigations. The office of chief counsel ... may, on its own initiative, undertake and complete an investigation of any other matter within the jurisdiction of the committee otherwise coming to the attention of such office.") (second emphasis added).

257. Wilkins, supra note 15 , at 874 . Professor Wilkins argues that more investigation could be done, even allowing for structural limitations on the extent of agencies' zealousness. He asserts that disciplinary counsel could conduct random "quality audits" and standardize the expectations of clients and lawyers. Id. Similarly, disciplinary bodies could conduct random spot checks of attorney conduct involving unrepresented adversaries and seek to standardize expectations. What those standardized expectations would be depends on whether additional ethical rules are adopted, as recommended in Part III.B infra. 
any, complaints alleging attorney misconduct against unrepresented parties are filed. It is hardly surprising that no one seems to be filing complaints, however, when one considers who typically files a disciplinary complaint. "[T]he vast majority of the complaints coming to the attention of the disciplinary system are filed by clients."258 The "clients" in the New York City Housing Courts, for example, are the landlords, who have no incentive to file complaints against their own lawyers for this behavior. ${ }^{259}$ Landlords' lawyers, if they recognize the behavior as improper at all, have no incentive to file complaints against their colleagues. In all areas of the law and types of misconduct, lawyers traditionally refrain from filing complaints against one another due to the absence of any tangible benefit for reporting misconduct and the risk of retaliation or loss of reputation in their practice community. ${ }^{260}$ This "old boy network" problem is exacerbated in contexts where one party to a dispute typically is unrepresented; most of the lawyers in the system have similar, rather than competing, interests to those of the lawyer whose misconduct is at issue. Judges and mediators are not present in unmonitored hallway and office negotiations. Further, given the volume of cases in "poor people's courts," these judicial officers depend on negotiations and stipulations to maintain control over their dockets. ${ }^{261}$

The burden of reporting misconduct thus falls on the unrepresented parties. Unrepresented parties, however, are unlikely even to perceive the problem. ${ }^{262}$ In Housing Court, tenants are regularly instructed

258. Wilkins, supra note 15 , at 823 ; see also id. at 824 (describing "paradox of agency problems" as the fact that clients in the best position to identify the lawyer misconduct-corporate clients - are the least likely to bring their complaints to the attention of disciplinary authorities); id. at $823 \mathrm{n} .92$ (citing a variety of sources supporting this assertion). Unrepresented parties are, by definition, no one's "client," and therefore in an even worse position. Moreover, since the represented parties in the situations I describe often do not come to court themselves, clients might not even be in a position to identify much of the misconduct that goes on. See supra text accompanying note 123.

259. See Wilkins, supra note 15 , at 823 ("These clients, however, have little incentive to report strategic behavior taken on their behalf.").

260. See id. at 822-23.

261. Wilkins seems to ignore the possibility that the court system might benefit from the attorney misconduct, and therefore not lave an interest in curbing it. Wilkins does identify other impediments to the filing of complaints by court personnel: the fact that the court may not feel that its role is to intervene in the ethical problem or that it may prefer to use different controls at its disposal. See id. at 823. The role of the courts in responding to these ethical problems is discussed in Part IIl.C infra.

262. Wilkins identifies the following impediments facing "one-shot" participants in their ability to use the disciplinary systems against their lawyers:

As "one-shot" participants in the legal marketplace, individual clients are subject to each of the three major information asymmetries that foster agency problems: they do not know what services they need, they do not have access to information that would allow them to predict the quality of the services that a particular lawyer is likely to render, and they do not have a sufficient baseline from which to evaluate the quality of the services performed. 
by the court to talk to the landlords' lawyers to try to settle the case. ${ }^{263}$ Given the imprimatur of legitimacy these negotiations are given by the court, the tenants are led to believe such negotiations are proper. Further, in most imstances the tenant has no one else from whom she can seek guidance about her case. In such a situation, tenants may even initiate a conversation with the landlord's lawyer, the only expert at hand, in order to obtain information or advice. If a tenant feels badly treated by the landlord's attorney, she may write off the misconduct as "just the way lawyers behave." Even if a tenant believes that improper behavior has occurred, she likely faces more urgent problems such as eviction or the need to deal with various governmental agencies. The likelihood that she would at the same time be willing and able to file, and follow through with, a disciplinary complaint is slim. ${ }^{264}$

Even when disciplinary actions are initiated, they are not easy to prove. In most instances, since negotiations take place behind closed doors or in the rush of the hallway, allegations would simply be one person's word against another's. ${ }^{265}$ Difficulties of proof, however, do not compel a conclusion that proceedings should not be initiated. First,

Id. at 829. The "one-shot" adversary would be at least as poorly situated as the "one-shot" client to use the disciplinary system against an opposing lawyer.

263. See, e.g., Brody, supra note 133, at B21 ("The judges urge tenants and landlords to try to work out their problems before a ruling."). One legal services office reports that it is the regular practice in Brooklyn Housing Court for the court to inform pro se tenants who appear in a trial part for the first time that they must wait until their case is called or until they can speak to their landlord's attorney. See Brooklyn Legal Services, Draft Complaint, supra note 147, at 23.

Court pressure to settle is prevalent in consumer and family law cases as well. See supra notes $188,211-213$ and accompanying text.

264. For example, a 1994 report submitted to the ABA's Consortium on Legal Services and the Public included numerous findings that would cast doubt on the likelihood that poor litigants would voluntarily subject themselves to legal forums of any kind, including those that handle disciplinary proceedings. See REESE \& ElDRED, supra note 176, at 8-9. The study found, among other things, that low-income litigants had a lower rate of contact with the legal/judicial system than did moderateincome litigants (23\% to $29 \%$ ), that low-income litigants were significantly more likely to take no action in response to legal needs (38\% to $26 \%$ ), and that low-income litigants reported less positive satisfaction ratings to legal advocates, courts and dispute resolution mechanisms than did moderateincome litigants. See id. at 41-42; see also Bezdek, supra note 14; White, supra note 14.

265. For example, in New York City Housing Court, the attorney mistaken for the judge by a tenant insisted that the reporter must not have overheard the entire interaction. See Brill, supra note 137, at 15. Similarly, the Missouri Supreme Court's reversal of the finding of a DR 7-104(A)(2) violation in Schiff may well be explained by an absence of proof as to what was said. In re Schiff, 542 S.W.2d 771, 775 (Mo. 1976). In Attorney $Q$, whether the attorney disputed what he was alleged to have said is unclear from the record; on appeal, the issue was how the statements should be interpreted, not whether they were said. Attorney Q v. Mississippi State Bar, 587 So. 2d 228, 233 (Miss. 1991).

The difficulty in prosecuting these kinds of disciplinary cases is further underscored by the fact that the litigation involving DR 7-104(A)(2) usually arises after the formerly unrepresented litigant obtains counsel. See, e.g., W.T. Grant Co. v. Haines, 531 F.2d 671 (2d Cir. 1976); Attorney $Q, 587$ So. 2d at 233; Schiff, 542 S.W.2d at 775 (reversing finding of DR 7-104(A)(2) violation with no indication that unrepresented litigant ever obtained counsel). 
the testimony of an impartial observer may be more credible than that of an attorney facing discipline. Second, to the extent that "word would get around" that proceedings were mitiated-by no means a safe assumption given the private nature of disciplimary proceedings-the proceedings may have a chilling effect on misconduct withm the legal community at large, regardless of their outcome. ${ }^{266}$

Finally, even if proceedings are successfully prosecuted, the sanction may not be any more than a slap on the wrist. ${ }^{267}$ Single instances of improper advice-giving may garner less punishment than other comparably serious misconduct, such as misappropriating client funds. Nonetheless, it remains worthwhile to pursue disciplinary actions that can address repeated misconduct and promote individual and profession-wide deterrence.

Critics of the disciplinary process, however, question the wisdom of relying on disciplinary proceedings to curb the behavior. "Critics of this form of regulation ... assert that disciplinary committees are slow, costly, and inherently biased in favor of lawyers."268 According to Professor Rhode, "every major study of bar disciplinary agencies has found them grossly unresponsive ... to serious misfeasance ...."269 Professor Abel's condemnation is sweeping:

[S] tudy after study has shown that the current rules of professional conduct are not enforced. Misconduct is rarely perceived. If perceived, it is not reported. If reported, it is not investigated. If investigated, violations are not found. If found, they are excused. If they are not excused, penalties are light. And if significant penalties are imposed, the lawyer soon returns to practice, in that state or another. ${ }^{270}$

266. Wilkins argues in favor of open and accessible enforcement proceedings, since they allow us to "begin to construct a more precise picture of how lawyers should actually reconcile their competing responsibilities." Wilkins, supra note 15 , at 884 .

267. For example, in Attorney $Q$, the sanction was a private reprimand. 587 So. $2 \mathrm{~d}$ at 234 . While the reprimand was more severe in Schiff, numerous ethical violations were involved. 542 S.W.2d at 775 . In 1994, without explanation, the Ohio Supreme Court reduced a penalty from a oneyear suspension to a public reprimand where the lawyer had failed to disclose to an unrepresented party that he represented the adverse party. See Disciplinary Counsel v. Rich, 633 N.E.2d 1114, 1116-17 (Ohio 1994); see also Abel, supra note 4, at 648-49; Rhode, supra note 217, at 214-16.

268. Wilkins, supra note 15, at 812 (citing Deborah L. Rhode, The Rhetoric of Professional Reform, 45 MD. L. REv. 274, 278-93 (1986)).

269. Deborah L. Rhode, Why the ABA Bothers: A Functional Perspective on Professional Codes, 59 Tex. L, Rev. 689, 718 (1981). "A survey of disciplinary screening procedures in California, Illinois, Michigan, and New York City revealed that between ninety-one and ninety-seven percent of complaints were dismissed with no investigation." Id.

270. Abel, supra note 4, at 648-49 (footnotes omitted); see also Lowenthal, supra note 5, at 44142 ("The most revealing rationalization for rejecting tough ethics rules against dishonest lawyering is the argument that it would be hypocritical to have such rules because lawyers would violate them too often."). 
Given these kinds of limitations, disciplinary controls alone are unlikely to solve the problem of impermissible advice-giving and negotiations.

The use of disciplinary proceedings to curb impermissible advicegiving raises issues of effectiveness and resource allocation. The increased use of disciplinary proceedings must nonetheless be an integral part of an overall enforcement strategy. Appropriate bodies must step forward to enforce the ethical rules and make such enforcement an effective deterrent. Otherwise, the practice of giving advice to unrepresented parties during negotiations, misconduct that reflects badly on the profession and harms disadvantaged parties, is de facto condoned by the legal profession.

\section{B. Enactment of Additional Rules Regulating Negotiations Between Lawyers and Unrepresented Adversaries}

The profession should not only enforce the existing disciplinary rules, but also adopt additional rules governing interactions between attorneys and unrepresented party opponents. Depending on whether the rules are to be enforced by the existing disciplinary bodies, the courts in which the attorneys practice, or a new regulatory body, this response to the problem could implicate the disciplinary controls, institutional controls, or legislative controls discussed by Professor Wilkins. ${ }^{271}$ Adoption of additional rules would increase protections for lay litigants and provide additional guidance to lawyers. The process of adopting new rules, by focusing the bar's attention on the problem, might also contribute to a curtailment of misconduct. ${ }^{272}$

As discussed in Part I, DR 7-104(A)(2) and Rule 4.3 have been interpreted to prohibit a wide range of behavior. ${ }^{273}$ Many attorneys, however, may not understand the extent to which the rules limit attorneys' interactions with unrepresented adversaries. The widespread nature of the misconduct itself suggests a lack of familiarity with the rules.

DR 7-104(A)(2) and Rule 4.3 offer only a partial solution. It is also important to adopt specialized rules in response to ethical problems arising in more particularized circumstances. ${ }^{274}$ For example, New York has adopted specific disciplinary rules for divorce lawyers that attempt to strengthen the rights of divorce clients by requiring a warning

271. Professor Wilkins recognizes the adoption of new rules as an important part of the enforcement scheme. See Wilkins, supra note 15 , at 879-83.

272. See, e.g., Lowenthal, supra note 5, at 444 ("The promulgation of rigorous ethics rules, coupled with their inclusion in law school curricula and bar examinations, may influence professional socialization, even without significant changes in enforcement.").

273. See supra Part I.C.

274. See Wilkins, supra note 15, at 875 ("[S]pecialized rules and enforcement practices can be tailored to the unique requirements of these regulatory contexts without undue confusion or contradiction."). 
analogous to a Miranda warning. ${ }^{275}$ In announcing the new rules in 1993, Judith S. Kaye, Chief Judge of the New York Court of Appeals, spoke about the need to address public cynicism about lawyers and judges, particularly in the context of cases involving matrimonial matters, which "are unequaled in stress and emotion."276

The widespread problem of lawyers taking advantage of unrepresented litigants calls for a similar response. While differences exist between a landlord-tenant case, a consumer dispute, and a divorce action, the stress and emotion levels run high in each type of case, as does the danger that lawyers will take advantage of lay litigants. Putting special limits on lawyers in particularized settings may help turn the tide on the public cynicism about lawyers and judges to which Chief Judge Kaye referred.

States should adopt rules that specifically describe the behavior that is prohibited when an attorney deals with an unrepresented opponent, including statements made in the course of negotiations. New rules should err on the side of protecting the unrepresented party, even at the risk of impeding the lawyer's ability to obtain a quick settlement.

New rules could be fashioned in a number of ways. For instance, new rules could set forth the limitations developed in decisions interpreting Canon 9, DR 7-104(A)(2), and Rule 4.3 of the Model Rules. The rules could instead, or in addition, impose a duty of fairness on a lawyer negotiating with an unrepresented adversary, prohibit a lawyer from obtaining an unconscionable agreement from an unrepresented party, or impose on the lawyer duties toward the tribunal and/or the unrepresented adversary different from those where the adverse party is represented.

Early drafts of the Model Rules included a provision requiring "Fairness to Other Participants" and prohibiting unconscionable transactions. ${ }^{277}$ Proposed Rule 4.2 provided that "[i]n conducting negotiations a lawyer shall be fair in dealing with other participants."278

275. See N.Y. Comp. Codes, R., \& REGs. tit. 22, §§ 1400.1-1400.5 (1994). In addition, under the rules, divorce clients are entitled to a written fee schcdule and itemized bills, and Iawyers are no longer able to take a client's home for unpaid fees. The rules also explicitly prohibit sexual relations between a lawyer and a client during a case. See id.

276. Hoffman, supra note 228 , at AI.

277. See Model Rules of Professional Conduct Rule 4.2 (Discussion Draft 1980), in GILLERS \& SIMON, supra note 66, at 261.

278. Model Rules of Professional Conduct Rule 4.2(a) (Discussion Draft 1980), in Gillers \& Simon, supra note 66, at 261. Professors Bellow and Kettleson had earlier proposcd a series of rules designed to modify lawyer adversariness "to protect weak parties from being exploited by more powerful opponents." Bellow \& Kettleson, supra note 102 , at 387 . Their proposals includcd a prohibition against "taking advantage of another's misinformation, ignorance or inexperience" and a greater obligation on lawyers proceeding against unrepresented parties "to avoid misrepresentation...." Id. For a full list of the proposals offered by Professors Bellow and Kettleson, see id. at 387-88. 
Proposed Rule 3.6 also prohibited lawyers appearing against pro se opponents from "unfairly exploiting... ignorance of the law or the practices of the tribunal." 79 Proposed Rule 4.3 prohibited lawyers from concluding an agreement that "would be held to be unconscionable as a matter of law."280 After "vigorous opposition" from the bar, the provisions were defeated and replaced with the current language of Rule 4.3. ${ }^{281}$ Though the fairness and unconscionability proposals were greeted with disapproval within the profession, the severity of the problem and the level of public cynicism warrant a reconsideration of such rules. Either rule, if adopted, would provide only a partial solution to the problem of impermissible advice-giving. The duty of fairness, although laudable, may be too vague to be effective. The prohibition against concluding unconscionable agreements requires a subsequent challenge to the agreement, an unlikely event due to the shortage of available counsel. ${ }^{282}$

Another possible rule change is to require the lawyer to disclose to the tribunal certain facts or potential legal claims of the unrepresented adversary to insure that the outcome of the proceeding is balanced. Rule 3.3(d) currently requires that "[i]n an ex parte proceeding, a lawyer shall inform the tribunal of all material facts known to the lawyer which will enable the tribunal to make an informed decision, whether or not the facts are adverse." 283 The comment to the rule justifies the modification of the lawyer's typical obligations under the adversary system as follows:

[I]n an ex parte proceeding, such as an application for a temporary restraining order, there is no balance of presentation by opposing advocates. The object of an ex parte proceeding is nevertheless to yield a substantially just result. The judge has an affirmative responsibility to accord the absent party just

279. Model Rules of Professional Conduct Rule 3.6 (Discussion Draft 1980), in Gillers \& Simon, supra note 66, at 277.

280. The full text of Proposed Rule 4.3 in the 1980 Discussion Draft was as follows:

Illegal, Fraudulent, or Unconscionable Transactions. A lawyer shall not conclude an agreement, or assist a client in concluding an agreement, that the lawyer knows or reasonably should know is illegal, contains legally prohibited terms, would work a fraud, or would be held to be unconscionable as a matter of law.

Model Rules of Professional Conduct Rule 4.3 (Discussion Draft 1980), in Gillers \& Simon, supra note 66, at 261.

281. See RHOdE \& LUBAN, supra note 9, at 772; see also HAZARD ET AL., supra note 9, at 1073 (discussing the rejection of Proposed Rule 4.3); Perschbacher, supra note 4, at 97 n.119 (same).

282. See, e.g., supra text accompanying notes 148-151. The requirements might nonetheless be desirable if only as statements of professional norms. They may also be important mechanisms for controlling negotiations outside the scope of litigation.

283. Model Rules of Professional Conduct Rule 3.3(d) (1989). Bellow and Kettleson also recommend that the ethical rules "requir[e] counsel for the represented party to advise the court or other decision-maker of any defenses counsel has reason to believe are available ...." Bellow \& Kettleson, supra note 102 , at 387. 
consideration. The lawyer for the represented party has the correlative duty to make disclosures of material facts known to the lawyer and that the lawyer reasonably believes are necessary to an informed decision. ${ }^{284}$

A case involving a lawyer and an unrepresented adversary is often more analogous to an ex parte proceeding than the profession has been willing to recognize. As in an ex parte proceeding, a balanced presentation by opposing advocates is unlikely, yet its object is still a substantially just result. Imposing a duty on the lawyer to disclose material facts and potential claims in situations where the opposing party is unrepresented would assist the court in achieving the goal of a just result. ${ }^{285}$

An affirmative requireinent that the lawyer disclose facts and potential claims to the court inay be the most effective of the various proposals. Requiring the disclosure of relevant facts and claims would allow the court to monitor the negotiation before it approves an agreement. This kind of monitoring should affect the attorney's behavior during negotiations and influence the terms of the proposed agreement. On the other hand, a disclosure rule would not address the problem of negotiations outside the scope of litigation. Such a requirement also would raise problems of legal ambiguity, since lawyers inevitably will dispute the range of material they are required to disclose, including which facts are inaterial and which claims are non-frivolous. It also would increase the time the court must spend on each case. As discussed more fully in Part III.C, the limited anount of time inany courts currently spend on each case due to high case volume is a major impediment to improved oversight by the courts.

While the adoption of new ethical rules to regulate negotiations between lawyers and unrepresented adversaries is an important component of the response to the problem of unethical advice-giving, it is not an easy task. The profession's resistance to the inclusion in the Model Rules of provisions requiring fairness in negotiations or prohibiting unconscionable agreeinents underscores the difficulties involved in instituting such changes, even if they are limited to situations involving unrepresented parties. ${ }^{286}$ Any attempt to adopt new rules also involves the risk that the rules will be drafted to protect lawyers rather than the

284. Model Rules of Professional Conduct Rule $3.3 \mathrm{cmt}$. (1989); see also Joseph M. McLaughlin, Note, An Extension of the Right of Access: The Pro Se Litigant's Right to Notification of the Requirements of the Summary Judgment Rule, 55 FORDHAM L. REv. 1109 (1987) (justifying intrusions by the court into the adversary process in the context of pro se litigation in the name of its truth-seeking function).

285. I am grateful to Professor Russell Pearce for suggesting the analogy to Rule 3.3(d).

286. Commentators have noted the difficulty in promulgating rules for negotiations in general. See, e.g., Lowenthal, supra note 5, at 412-13 (discussing the failure of the Model Rules to address honesty in negotiations); Perschbacher, supra note 4, at 133 (exploring the structural problems of our adversarial system that prevent the imposition of a duty to negotiate in good faith). 
public. As Professor Gillers observed in his critical analysis of the Model Rules:

The lawyers who approved the Rules looked after their own. They have given us an astonishingly parochial, self-aggrandizing document, which favors lawyers over clients, other persons and the administration of justice in almost every line, paragraph, and provision that permits significant choice. ${ }^{287}$

The danger of such a result seems particularly pronounced when the identity of probable participants in the drafting process is considered. As the foregoing analysis on disciplinary proceedings reveals, the poor, unrepresented litigants who are likely to need the protections of the rules cannot reasonably be expected to participate in the process. Whether other participants would represent the interests of unrepresented litigants is hard to predict; however, past experience suggests that the interests of unrepresented parties would not be fully represented.

The risk that the profession will ignore the interests of unrepresented litigants is palpable, notwithstanding statements such as those made in the Preamble to the ABA Model Rules of Professional Conduct: "The legal profession's relative autonomy carries with it special responsibilities of self-government. The profession has a responsibility to assure that its regulations are conceived in the public interest and not in furtherance of parochial or self-interested concerns of the bar."288

An attempt to adopt more stringent ethical rules likely will be opposed by attorneys whose ability to obtain quick and favorable settlements from unrepresented litigants would be constrained. Even if powerful sections of the profession overcome their self-interest and adopt rules protecting unrepresented adversaries, a change in rules alone cannot constitute the entire enforcement strategy. The extent to which rule changes alone will affect outcomes is very much open to dispute. ${ }^{289}$ Enforcement problems are likely to plague any ethical rule.

287. GiLlers, supra note 8, at 245. "The American legal profession has had a sad history of adopting ethical rules that have enriched its pocketbook but which it sought to justify as protecting clients." Id. at 268; see also Rhode, supra note 269, at 691 ("Without impugning the good faith of those involved in the [crafting of the Model Rules], it is legitimate to inquire whether the bar as a whole can rise above parochial concerns on issues that place its income or status at risk.").

288. Model Rules of Professional Conduct Preamble (1983).

289. As Professor Galanter argues in his classic study explaining why the "haves" come out ahead of the "have nots,"

Rule change is in itself likely to have little effect because the system is so constructed that changes in the rules can be filtered out unless accompanied by changes at other levels.... The system has the capacity to change a great deal at the level of rules without corresponding changes in everyday patterns of practice or distribution of tangible advantages.

Galanter, supra note 158, at 149 (footnote omitted). Referring primarily to DR 7-104(A)(2) and Rule 4.3 in the context of interviews of potential defendants or witnesses who are unrepresented, one commentator has noted that "it would be sheer wish fulfillment to assume that the aforementioned 
Despite institutional opposition, new rules are needed to protect pro se litigants who are at the mercy of attorneys in unmonitored negotiations. As part of a total enforcement strategy to address attorney misconduct, more stringent ethical rules would help regulate the rampant misconduct that occurs in negotiations between lawyers and unrepresented parties. Since the new rules alone, however, cannot eliminate the misconduct, the enforcement strategy must go beyond the enforcement of ethical rules by professional disciplinary bodies.

\section{Oversight By The Courts}

Court oversight, or, in Professor Wilkins' terminology, increased institutional control, ${ }^{290}$ is an important component of a response to the problem of impermissible advice-giving. At least some attorney misconduct occurs in the context of court proceedings or is evident in such proceedings. Courts should play an increased role in vacating stipulations, declining to approve stipulations in the first place, and referring instances of attorney misconduct to the appropriate disciplinary committee. The negotiation process also could be restructured to give judges, their assistants, or mediators an increased presence in negotiations, thereby reducing the opportunity for unmonitored interactions between attorneys and their unrepresented adversaries.

Each of these responses, however, has problems and limitations. Courts already possess the power to vacate stipulations, and have exercised that power. ${ }^{291}$ Despite the significant number of decisions vacating stipulations, when compared to the total volume of cases, use of the vacatur is rare. ${ }^{292}$ An examination of the vacatur process reveals why vacatur is so rare. The legal and factual arguments supporting vacatur are often complex, and not necessarily apparent to the unrepresented litigant. Arguments in support of vacatur are typically articulated only after the litigant subsequently has obtained counsel. ${ }^{293}$ Given the shortage of available lawyers for the poor, however, litigants do not obtain lawyers after the signing of stipulations or contracts any more successfully than they do earlier in the proceeding. Moreover, to expect courts facing crushing volume to raise the challenge sua sponte or regularly to

rules effectively deter overreaching and manipulation." RiCHARD H. UNDERWOOD \& WiLLIAM H. Fortune, Trial Ethics 194 (1988).

290. See Wilkins, supra note 15 , at 807-08.

291. See, e.g., cases cited supra notes 148-149.

292. As shown in the Housing Courts and courts handling family matters, for example, the huge volume of cases is resolved mostly by settlement. See, e.g., supra notes 111-115, 206-210, and accompanying text. The cases vacating stipulations are relativcly few in number. See, e.g., supra notes 148-149, 239-243, and accompanying text.

293. See, e.g., cascs cited supra notes 148-149, 239-243. 
undo their work only to create more work is unrealistic. ${ }^{294}$ For all of these reasons, vacatur will not be the most effective institutional control for regulating misconduct against unrepresented parties.

Another approach to increased court oversight is court investigation of stipulations and settlements before approval, reserving to the court the power to withhold approval of those that seem to be unfair or the likely product of attorney misconduct. Increased court scrutiny of agreements prior to approving stipulations in the first place is a recurring theme in the studies of courts such as the New York City Housing Courts. ${ }^{295}$ A detailed inquiry by the court prior to approval of a proposed agreement would help to protect against unrepresented litigants waiving their rights. The court's efforts to identify the underlying facts and potential claims would work well in conjunction with rule changes imposing on lawyers the disclosure duty discussed in Part III.B.

Even with such a duty imposed on lawyers, however, a court inquiry into the facts and claims involved would increase the time necessary to resolve each case. So long as courts continue to pressure the litigants to settle and provide only a few minutes of oversight, they cannot conduct more than a cursory inquiry. Unless the volume of cases decreases, or the courts' resources increase, there are limits to the time that courts can devote to each case. Moreover, many of the legal and factual issues involved in these cases are complex; unless the unrepresented litigant subsequently obtains counsel to investigate and articulate the issues, a well-intentioned judge might not recognize a waiver of rights. ${ }^{296}$ Finally, the more comprehensive a court's inquiry in each case, the more it runs the risk of both slowing down its own ability to manage its docket and appearing to be biased towards unrepresented litigants. Landlords' advocates already view New York Housing Court, where most tenants are unrepresented, as pro-tenant, ${ }^{297}$ and some divorce lawyers view the family law courts as providing advantages for unrepresented parties. ${ }^{298}$

The proposal involving referral of cases of misconduct to disciplinary bodies faces similar hurdles. It presumes that courts can and will uncover misconduct. In order to do so, the court must commit

294. Wilkins cautions in general that, since most cases settle with little or no judicial intervention, "the extent of judicial scrutiny should not be exaggerated." Wilkins, supra note 15 , at 835 . He also notes the extent to which "the current emphasis on case management seems likely to discourage judges" from intervening in certain instances of attorney misconduct. Id. at 842-43.

295. See, e.g., 5 Minute JUSTICE, supra note 105, at 92; JUSTICE EvictED, supra note 119, at 51-52; MLRI SUMmary Process SURvey, supra note 163, at 115-22.

296. See, e.g., 144 Woodruff Corp. v. Lacrete, 585 N.Y.S.2d 956, 960 (N.Y. Civ. Ct. 1992).

297. See, e.g., Miller v. Silbermann, 832 F. Supp. 663 (S.D.N.Y. 1993) (describing allegations of landlords' groups that the systemic operation of the Housing Court deprives landlords of their due process and equal protection rights).

298. See supra note 201 and accompanying text. 
additional time and resources to an inquiry into the facts of the case and the agreement. Factual disputes between the parties regarding what transpired during negotiations present similar problems of proof to those discussed above in the context of disciplinary proceedings. "Coaching" by the attorney of the unrepresented litigant might impede the court's ability to uncover the misconduct. ${ }^{299}$ Finally, whether the court would regularly take steps adverse to the interests of the court's "repeat players" is questionable. ${ }^{300}$ Judges may also prefer to use institutional controls at their disposal, rather than referrals to the disciplinary proceedings, to address attorney misconduct. ${ }^{301}$ Courts will need to overcome these hurdles to effective policing of the bar, as they utilize their authority and responsibility to refer instances of misconduct to disciplinary bodies. ${ }^{302}$

A final response to the problem is for courts to attempt to reduce the incidence of unmonitored discussions. Assuming that unmonitored settings such as the hallway setting in New York City's Housing Courts provide ripe grounds for misconduct, removing the communications from that setting would have an ameliorative effect. One New York study recommended that "no negotiations should take place between an attorney and an unrepresented party except in front of a judge or duly assigned mediator. ${ }^{303}$

While increased monitoring of the negotiation process by the court would influence attorney behavior, a number of concerns must also be recognized. First, the court's ability to monitor negotiations will be affected by limited resources as discussed above; while a modification of court practices may alleviate the problem, increased oversight will require increased resources. A second and related concern is that courts may not choose to exercise such power so long as the ability to move the docket depends on the occurrence of the negotiations. Third, court oversight will not reach negotiations outside the litigation context. ${ }^{304}$ Finally, even where litigation is involved, it is hard to imagine that the

299. Recall the "coaching" of one landlord's lawyer to an unrepresented tenant in the context of a hallway settlement: "If the judge sees this doubtful look on your face or he thinks l'm taking advantage of you, it'll take hours. .. . But if you say you understand, we'll be out of here." Hoffman, supra note 104, at A1.

300. See generally Galanter, supra note 158, at 119-22 (describing low the structure of the litigation system tends to favor repeat players).

301. See Wilkins, supra note 15 , at 823 .

302. See, e.g., MOdel CODE of Judicial Conduct Canon 3(D)(2) (1990) ("A judge who receives information indicating a substantial likelihood that a lawyer has committed a violation of the Rules of Professional Conduct ... should take appropriate action.").

303. 5 MinUTE JUSTice, supra note 105 , at 92.

304. As the situations involving prenuptial agreenents reveal, many negotiations between lawyers and unrepresented litigants occur in advance of litigation. See, e.g., In re Marriage of Foran, 834 P.2d 1081 (Wash. Ct. App. 1992). 
court could successfully prohibit discussions on a previous day, or any time before or after negotiations under the court's auspices occur.

Court oversight may not only be ineffective as a safeguard to monitor and prevent attorney misconduct, it may actually be harmful to unrepresented parties - who are often poor, women, and racial minorities. ${ }^{305}$ Court personnel and court policies have been criticized for being unresponsive and even abusive to those same unrepresented litigants. In the context of the New York Housing Courts, observers report that certain comments and actions by judges exacerbate the difficulties facing unrepresented litigants. ${ }^{306}$ Nor do mediators solve the problem: "[o]bservers' comments on the mediation proceedings ... indicate that landlords' attorneys completely dominate the mediation process in all boroughs." 307

A scathing attack on the role of judges appears in Mark $\mathrm{H}$. Lazerson's article entitled In the Halls of Justice, the Only Justice Is in the Halls. ${ }^{308}$ Lazerson's article describes the struggle of attorneys from one legal services office with the newly created Housing Court in the 1970s. Lazerson alleges that judges were particularly biased against tenants. As the title to his article asserts, Lazerson's view is that the

305. The ethical issue involving impermissible attorney advice-giving is only one problematic aspect of the cases involving attorneys and unrepresented litigants. For example, the likelihood that unrepresented litigants may waive significant rights is a troubling issue, possibly related to the attorney misconduct, but perhaps independent of such misconduct. See supra text accompanying notes 152-154.

306. See, e.g., 5 MiNuTE Justice, supra note 105, at 65-67 (quoting observers' notes):

"[A] landlord's attorney kept saying to the tenant, 'I can't hear you-speak louder,' while he kept an eye on [the judge] to see if [the judge] was becoming annoyed. Needless to say, the judge reprimanded the tenant for speaking loudly."

"... The tenant lost her command of English and started to cry. The judge shouted at her that she was crazy; the more he shouted the more she cried until she was hysterical and had a hard time breathing."

-...

"Landlord attorney to tenants: 'Drop dead.' Judge did not admonish."

....

"Judge wrote order for inspection; tenant continued to push issue, do I have to pay until repairs are made? Judge got fed up with tenant and ripped up stipulation and started screaming and shouting."

307. Id. at 42-43; see also id. at 65, 67-68 (quoting observers' comments on the mediators): "Mediator's sole job so far seems to be to read stipulations, drawn up by landlords' lawyers, to the tenants."

"Landlords' lawyers interrupt mediators in progress to use the phone on the mediator's desk, look at papers on the desk.... Mediators need training in responsibility of the role, and assertiveness."

“... Also the remark... by [mediator] makes me feel that "final judgments or judgments forthwith' are customarily written into stipulations ...."

308. Mark H. Lazerson, In the Halls of Justice, the Only Justice Is in the Halls, in 1 THE Politics of INFormal Justice 119 (Richard L. Abel ed., 1982). 
hallway is a friendlier setting for the unrepresented tenant than is the courtroom.

Hearing officers and landlord attorneys sought to replace the informal corridor negotiations with discussions inside the hearing room-an environment strongly biased against the tenant.

The tenant negotiating in the hallway was not under the Damoclean sword of eviction. Furthermore, the poor black or Hispanic tenant was not as verbally disadvantaged there as he was in the courtroom. In the corridor he could express his anger and demand justice in ghetto argot against a landlord who was often psychologically unprepared to confront those he oppressed. In the courtroom, the tenant's inarticulate fury would confirm his powerlessness. ${ }^{309}$

Current observers who call for increased oversight would contest Lazerson's view that unrepresented parties actually fare better in hallways. $^{310}$ Nevertheless, Lazerson's observations serve as a reminder that oversight can be harinful, rather than helpful, to unrepresented parties.

Concerns about the effect on litigants of actions by judges and mediators arise outside the New York City Housing Courts. As described above, courts handling consumer and family law cases routinely pressure unrepresented litigants to go settle the case with the lawyer, and the resulting agreements often favor the represented party..$^{311}$ A 1983 study of Boston Housing Court found that tenants fared particularly poorly when their cases were resolved before mediators. ${ }^{312} \mathrm{~A}$ study of Baltimore's rent court, entitled Silence in the Court, poignantly portrays and analyzes "the functional voicelessness of virtually all

309. Id. at 150 \& n.20. Whether Lazerson's description applies to most cases, or holds true in the 1990 s as well as the 1970 s, is difficult to assess.

310. The episodic observations quoted above might well be analyzed as supporting Lazerson's theory of the powerlessness of unrepresented tenants in the formal setting of the courtroom. See supra notes 306-307.

311. See, e.g., supra notes 188, 211-213, 263 and accompanying text.

312. See Engler \& Bloomgarden, supra note 163, at 5-7. Most cases in Boston Housing Court are funneled through the mediation process, where litigants appear before mediators known as "Specialists." The study found that "tenants fare significantly better before the judges than they do before the Specialists." Id. at 6 . The report's section on recommendations for reform included the following:

The most fundamental change in attitudes and practices among the Court personnel must take place with the Housing Specialists. As our statistics show, the bulk of non-default cases are resolved through settlements negotiated before the Specialists, and unrepresented tenants in these settlements capitulate virtually to all of their landlords' demands. That the allegedly neutral Specialists thus are orchestrating and sanctioning settlements in which tenants with presumably meritorious defenses "voluntarily" consent to the demands of their landlords, leads us to the conclusion that the Specialists play an integral role in the problems facing unrepresented tenants.

Id. at 115. See generally id. at $25 \mathrm{tbl} .13,46 \mathrm{tbl.23,115-20.}$ 
tenants in this forum." ${ }^{313}$ The study argues that the operational premise of the rent court serves to reinforce the rights of landlords while obscuring those of tenants. ${ }^{314}$ The tenants are typically unrepresented poor black women. ${ }^{315}$ Their social powerlessness compounds the institutional barriers raised by the rent court's systematic bias in favor of landlords.

A growing number of jurisdictions across the country have issued reports identifying institutional problems of gender bias or racial and ethnic bias in the courts. ${ }^{316}$ Prejudice against racial and ethnic minorities has been identified as affecting operation and outcomes of proceedings in the alternative dispute resolution context as well. ${ }^{317}$ The use of mandatory mediation in family law cases has been criticized especially where victims of domestic abuse must face their batterers. ${ }^{318}$ These studies and examples show a further danger of relying on institutional controls for the protection of unrepresented litigants, who are often women of color.

Squaring the need for judicial oversight with the dangers of oversight is no easy task. Since the attorney misconduct often occurs under the auspices of the courts and in the context of court proceedings, courts must have a role in curtailing that misconduct. Similarly, court personnel must increase their presence in the interactions between lawyers and their unrepresented adversaries. At the same time, there is ample concern about the detrimental effect that may result from court intervention, particularly to unrepresented litigants who are poor, women, and/or racial and ethnic minorities. Absent sensitive and careful intervention designed to ensure that the rights of unrepresented litigants are protected, court intervention may exacerbate, or even legitimate, the abuse experienced by litigants at the hands of lawyers.

\section{Changes in the Forum, the Rights, and the Advocates}

This Section discusses briefly a range of additional responses that have been proposed to the problems facing unrepresented litigants.

\footnotetext{
313. Bezdek, supra note 14, at 535.

314. See id. at 540.

315. See id.

316. See Deborah L. Rhode, Gender and Professional Roles, 63 FordHaM L. Rev. 39,57 (1994) ("During the 1980s and early 1990s, one federal circuit and about two thirds of state judiciaries established ... commissions to consider gender bias in the courts. About a third formed analogous groups to consider racial or ethnic bias."); see also id. at 57 n.68 ("[A]s of May 1993, 35 states, the District of Columbia, and two federal judicial circuits had established gender bias task forces, and ...26 had published reports.") (citing Kathleen L. Soll, Gender Bias Task Forces: How They Have Fulfilled Their Mandate and Recommendations for Change, 2 S. CAL. Rev. L. \& Women's STUD. 633, 634, 638 (1993)).

317. See generally Richard Delgado et al., Fairness and Formality: Minimizing the Risk of Prejudice in Alternative Dispute Resolution, 1985 W1s. L. REv. 1359 (discussing institutional problems of prejudice in the alternative dispute resolution context).

318. See supra notes 233-234 and accompanying text.
} 
Some of the responses only indirectly address the ethical problem of lawyers giving impermissible advice to lay adversaries. Others are best viewed as more detailed components of the four major responses discussed in this Part.

\section{Changes to the Forum or Litigants' Rights}

Responses to the problems facing pro se litigants could include changing the substantive or procedural rights implicated in negotiations and the forums in which they occur. For example, the substantive or procedural rights of the litigants could be enhanced, ${ }^{319}$ cases appearing in a particular "poor person's court" could be transferred to another forum, such as an administrative agency, or lawyers could be excluded from a particular forum. Although these responses attempt to strengthen the pro se litigant's position vis-a-vis the lawyer, none solves the ethical problem of attorney misconduct per se.

Increasing the substantive rights of the litigants who typically appear without counsel would constitute a welcome response for many groups of people regularly subjected to court proceedings. In the housing context, for example, rent and eviction controls could be strengthened or subsidies increased. These changes might reduce the likelihood that the cases appear in court in the first place or alter the balance of power once the cases are in court. However, these changes do not respond directly to the ethical problem of impermissible advicegiving. The danger that attorneys will advise, cajole, or manipulate unrepresented adversaries through negotiations is as much a hazard where the tenant has many defenses as where she has few. ${ }^{320}$ The ethical violations would only be affected if new ethical rules prohibited the making of unconscionable agreements, since the more rights the tenant has to lose, the greater the likelihood the one-sided agreement will be unconscionable.

Procedural changes that regulate the lawyers' negotiations with unrepresented parties could comprise a component of a court's efforts to use institutional controls to curb impermissible advice-giving. For example, procedural changes could require lawyers to disclose to the court facts or potential claims of an unrepresented adversary, through

319. For recommendations similar to these, see 5 MINUTE JUSTICE, supra note 105, at 91-96; Justice EvicTED, supra note 119, at 48-52; STEMMING THE TIDE, supra note 132, at 66-74; Moulton, supra note 173, at 1669-75.

320. The examples of the New York and Boston Housing Courts as likely settings for abuse simply underscore this point. Although tenants in Boston and New York City possess many more rights than in most other jurisdictions, the attomey abuse is rampant. This is not to say that increasing the substantive rights would not be a good idea. The elimination of rent control in Boston, Cambridge, and Brookline, Massachusetts and the cutbacks of federal subsidies, however, suggest that changes in the near future will diminish, rather than expand, existing rights. 
submission of a certification or oral statement to the court. Courts could require the use of standardized settlement agreements, tailored to the proceedings heard in that court. Courts could attempt to restrict the discussions between lawyers and their adversaries, limiting negotiation to the exchange of settlement terms on paper, where the court is unable to monitor the face-to-face negotiations. To enforce its rules, the court could institute a procedure for selective, after-the-fact review. A violation of the court's procedural rules, or the underlying ethical rules, could result in automatic vacatur of the agreement, if the unrepresented party chose to do so. ${ }^{321}$

The wisdom of adopting changes such as these will depend on the details of the rules. For example, the wisdom of using a standardized form will depend on the content of the form itself; the danger that the form adopted will further the interests of repeat players is a real one. ${ }^{322}$ New procedural rules, moreover, will only be as effective as their enforcement mechanisms. The impediments to increasing court oversight, discussed in Part III.C, remain. Requiring additional or standardized forms will serve little purpose if no one reads them. The idea also may be impossible to enforce, or may even work against the interests of the unrepresented party if the result is to force all cases to trial. Permitting spot checks or vacatur of the agreements will be ineffectual if the court remains driven more by its concern to move its docket than by its concern to ensure that unrepresented litigants are protected from attorney misconduct. Procedural changes need to be combined with effective oversight by the courts, and are the details of an oversight strategy by the courts, rather than a separate enforcement mechanism.

Changing the forum of disputes is another possible procedural response to the problem of impermissible advice-giving. For example, changing the forum to a less formal setting, such as an administrative agency hearing or an alternative dispute context, might render the forum more accessible to disadvantaged litigants. ${ }^{323}$ However, simply transferring the cases from one forum to another would not diminish the interactions between lawyers and unrepresented adversaries. Negotiations would be no less subject to attorney misconduct in the hallway

321. Some of these procedural changes are analogous to the new ethical rules discussed in Part III.B. In Professor Wilkins' terminology, imposing such requirements as procedural changes, rather than as ethical rules, employs institutional controls, rather than disciplinary controls. See Wilkins, supra note 15 , at $807-08$.

322. See generally Galanter, supra note 158 . The wisdom of restricting negotiations to a paper exchange depends in part on one's view of the wisdom of increased oversight in general. See supra Part III.C.

323. See, e.g., William H. Simon, Legal Informality and Redistributive Politics, 19 Clearinghouse Rev. 384, 384 (1985) ("Until recently... [t]he left critique [of the legal system] portrayed formality as facilitating the manipulation of the legal system by the privileged to the disadvantage of others."). 
of a different court or administrative agency than they are in their current setting. Nor would a change in the forum alone assure an improved outcome for the unrepresented litigant. ${ }^{324}$ Changing the forum without changing the players fails to address the ethical problem identified in this Article.

In contrast, barring lawyers from a particular forum would eliminate the ethical problem of lawyer negotiations with unrepresented adversaries in that forum. ${ }^{325}$ This solution to the ethical problem, however, not only might be subject to a due process challenge, ${ }^{326}$ but will raise other problems for those it was meant to help. Studies of California's Small Claims Court and Baltimore's Rent Court, settings in which lawyers play little or no role, deinonstrate that indigent parties are subject to systemic abuse even without the presence of attorneys. ${ }^{327}$ Coinmentators have also criticized the exclusion of lawyers from divorce mediation as leaving vulnerable parties, typically women, at the mercy of their inore powerful spouse. ${ }^{328}$ If the solution to the ethical issue compounds other problems for unrepresented litigants, as with the solution of increased judicial oversight, it is no solution at all. ${ }^{329}$

324. As Professor Galanter has demonstrated, the "haves" will likely adapt to the new setting and continue to employ their strategic advantages over the "have nots." See Galanter, supra note 158 , at 119-22; Moulton, supra note 173, at 1669-75. Where the change is to a less formal setting, the change may exacerbate the problems facing the poor. See, e.g., Richard Abel, Informalism: A Tactical Equivalent to Law?, 19 CLEARINGHouse REv. 375, 379-83 (1985). "Recent studies indicate that racial, gender and cultural biases may play a role in a significant number" of decisions by administrative law judges, particularly decisions "affecting some of society's most disadvantaged members." Elaine Golin, Solving the Problem of Gender and Racial Bias in Administrative Adjudication, 95 Colum. L. REv. 1532, 1533 (1995) (footnotes omitted).

325. California, for example, excludes lawyers from its small claims court and from divorce mediation. Cal. Civ. Proc. Code § 116.530 (West 1996); Cal. Fam. Code § 3182(a) (West 1996).

326. The exclusion of counsel from the California Small Claims court was upheld under the reasoning that plaintiffs could choose a different forum, and defendants were entitled to a trial de novo on appeal. See Moulton, supra note 173, at 1676. This argument is not available where there is no trial de novo on appeal, as in the New York City and Boston Housing Courts. See Mass. GeN. L. ch. 231, § 113 (1988); Mass. Gen. L. ch. 239, § 5 (1985); N.Y. City Civ. CT. Act § 1703 (McKinney 1989); N.Y. Civ. Prac. R. § 5501 (McKinney 1995). Even where such a procedural option is available on paper, "[i]s the right to counsel for the 91 per cent of defendants who lose in small claims court 'guaranteed in a real sense' when it can be empirically demonstrated that fewer than 1 percent of them appeal?" Moulton, supra note 173, at 1676 (footnote omitted).

327. See generally Bezdek, supra note 14; Galanter, supra note 158; Moulton, supra note 173; see also Richard L. Abel, Socializing the Legal Profession, 1 L. \& PoL'Y Q. 5, 21 (1979) (observing that if advantaged parties were prohibited from using lawyers, they "could retain representatives who were not formally qualified as lawyers but possessed all of the lawyer's competence.").

328. See generally Bryan, supra note 233; Gagnon, supra note 211; Grillo, supra note 228. As noted above, the role played by the divorce lawyer has led to calls for deprofessionalization in the divorce context and the exclusion of lawyers from mediation. See supra notes 237-238 and accompanying text. Family law cases, however, have provided the context for litigation and legislation regarding a right to counsel. See In re Smiley, 330 N.E.2d 53 (N.Y. 1975); N.Y. FAM. CT. Acr $\$ 262(a)(v)$ (McKinney 1996) (providing a statutory right to counsel in custody proceedings in Family Court).

329. See supra Part 11I.C. 


\section{Lawyers-For-The-Day and Lay Advocates}

Increased use of lawyers-for-the-day and lay advocates or "certified paralegals" merits more serious consideration. Lawyers-forthe-day volunteer to sit in court and speak with litigants whose cases are to be heard that day. These lawyers attempt to help litigants identify material facts and potential claims for use in negotiation and before the court. ${ }^{330}$ However, unless the lawyer-for-the-day participates in negotiations as an advocate for the unrepresented litigant, this response fails to address the problem of impermissible attorney advice-giving. Litigants might be forewarned, but are no better armed. They are still prey to the opposing lawyer's impermissible advice-giving. Furthermore, it is unclear how effective this response would be to the overall problem of the vulnerable litigant. The lawyer-for-the-day may or may not be very familiar with the substantive law at issue in the forum. An attorney familiar with the law may not have the time to uncover the facts that might emerge from the investigation lawyers are expected to undertake on behalf of their clients. Even if the lawyer-for-the-day uncovers and articulates to the litigant potential claims, unrepresented litigants face serious impediments to litigating the claims. ${ }^{331}$ Absent an ability of the litigant to procure an advocate if the matter is not resolved successfully, the provision of a lawyer-for-the-day will be an empty gesture.

The increased use of lay advocates has long been viewed as a component of a program to expand access to the legal system. ${ }^{332}$ The legal profession's prohibition of the unauthorized practice of the law, however, generally forecloses the use of lay advocates. ${ }^{333}$ The profession's rules would require modification to allow the use of lay advocates. ${ }^{334}$

330. See, e.g., Golden, supra note 219 , at 1 :

[M]any lawyers who regularly practice in family court have begun volunteering one day each year to help impoverished pro se litigants. Most family courts now offer "lawyer for the day" services....

....

Pro se litigants take a number, and stand in line. Some wait as long as two hours.... As [litigants] explain their problems, [the lawyer for the day] finds the necessary forms, and fills them out by hand.

...

... With so much paperwork, [the lawyer for the day] can help only a dozen people in eight hours-just a small fraction of all the pro se litigants ....

331. See generally Bezdek, supra note 14; Fox, supra note 14; Moulton, supra note 173.

332. See, e.g., Bellow \& Kettleson, supra note 102, at $386 \mathrm{n} .193$ ("Much more effective lay and pro se representation would be a necessary component of any significant expansion of access and is also consistent with the long run deprofessionalization that seems to be necessary."). See generally Abel, supra note 327; Rhode, supra note 217; Deborah L. Rhode, Professionalism in Perspective: Alternative Approaches to Nonlawyer Practice, 23 N.Y.U. REv. L. \& Soc. Change 101 (1996).

333. See Model Rules of Profesional Conduct Rule 5.5 (1983).

334. See, e.g., id.; Model Code of Professional Responsibility DR 3-101 (1981). But see Rhode, supra note 217, at 216-21 (discussing the extent to which enforcement of the prohibition against the unauthorized practice of law has diminished). 
Whether the increased use of lay advocates would curtail impermissible attorney advice-giving depends on the role of the lay advocate in a particular setting. The trend toward easing the restrictions on lay competition has begun with "do-it-yourself" kits and form preparation services for pro se litigants. ${ }^{335}$ If the lay advocate merely prepares forms and advises the unrepresented litigant, without representing the litigant in the negotiations, the lay advocate will not affect attorney misconduct for the same reason the lawyer-for-the-day fails to address the problem. If the lay advocate represents the litigant, then DR 7-104(A)(2) and Rule 4.3 no longer apply. The use of lay advocates should curtail the attorney misconduct for the same reasons the provision of counsel succeeds. ${ }^{336}$

The issue then becomes one of resources. ${ }^{337}$ If lay advocates are to be hired privately, it remains to be seen whether an indigent litigant can afford an effective lay advocate; the option may be more available for litigants who are not indigent. ${ }^{338}$ If the existence of lay advocates depends on public funds, this response will compete for resources with the expansion of publicly-funded counsel or increased oversight by the courts. ${ }^{339}$ As part of an overall strategy, the use of lay advocates therefore should be considered a component of efforts to increase the provision of counsel..$^{340}$

It is beyond the scope of this Article to explore the many arguments for and against the relaxation of the prohibition against the unauthorized practice of law. For an introduction to the subject, see Gillers, supra note 9, at 661-73; HAZARD ET AL., supra note 9, at 936-54; Rhode, supra note 217 , at 214-16.

335. See, e.g., Rhode, supra note 217 , at 213-14. Professor Rhode reports that when a Public Protection Committee in California took testimony on the rising trend in the unauthorized practice of law, "[v]irtually all of the comments and testimony focused on form-preparation services, primarily those designed for low income consumers." Id. at 222.

336. See infra Part III.E.

337. The use of lay advocates raises additional concerns. Unless the lay advocate is permitted to proceed to trial and skilled to do so, or unless counsel at that point is available, the effectiveness of the lay advocate in negotiating is limited. See, e.g., GiFford, supra note 10, at 67 "'The most important determinant of the negotiator's power over the other party is the nature of the alternatives to a negotiated agreement available to both the client and the other party."); see also FISHER \& URY, supra note I0, at 97-106 (discussing the concept of BATNA: the Best Alternative to a Negotiated Agreement, "[t]he better your BATNA, the greater your power."). Many legal services attorneys have had clients referred to them by lay advocates or community organizers who have reached the limits of their ability to advocate in the legal system despite their best efforts.

338. See, e.g., Rhode, supra note 217 , at 227 (reporting that "non-lawyer practitioners charged an average of $\$ 200^{\prime \prime}$ for bankruptcy and divorce work). For citations to reports of a $\$ 40$ to $\$ 250$ range nationally for paralegals for uncontested divorces, see $i d$. at 227 n.140.

339. But see Bezdek, supra note 14, at 562-63 (discussing Baltimore's Rent Court, where the lion's share of non-attomey assistance is used against, rather than for, the indigent litigant).

340. See, e.g., Rhode, supra note 217, at 229-30 ("[M]odifying unauthorized practice prohibitions is not a substitute for adequate government subsidies, pro bono services, or simplification of legal procedures. Rather, restricting the profession's monopoly should be seen as part of an overall strategy for expanding access to legal assistance."). 


\section{E. The Provision of Counsel}

Only the provision of counsel for each unrepresented litigant forced to negotiate with a lawyer would eliminate the problem of impermissible advice-giving. ${ }^{341}$ This solution deserves consideration in a discussion of an ethics problem arising from a lack of representation for two reasons. First, where counsel is provided to all who require it, the ethical problem of negotiation with an unrepresented party is solved. The unrepresented party no longer must go unrepresented. Second, beyond its merits as a response to the problem itself, the provision of counsel deserves special attention in any discussion of regulation of the profession. The distribution of lawyers, and the legal profession's current and historical inability to make counsel available to the poor in civil cases, raises fundamental concerns about the profession's ability to regulate itself and its continued enjoyment of its independent status. Although economic and political realities play a critical role in contributing to the current distribution of lawyers, the legal profession's determination to maintain a system of self-regulation and independence must be considered a source of the problem as well. ${ }^{342}$

The profession has the authority to target the supply of counsel to a particular group of clients. ${ }^{343}$ This may be accomplished, for example, through adoption of pro bono requirements. As with the adoption of new ethical rules discussed in Part III.B, solutions expanding the provision of counsel could implicate disciplinary controls, institutional controls, and legislative controls. Access to competent counsel for every person is a stated "aspirational goal" of the profession's ethical rules. ${ }^{344}$ The shortage of available counsel for the poor underscores the hollow nature of this aspiration. Increasing the availability of counsel is therefore an appropriate response for the profession to undertake in curbing its members' misconduct.

The institutional impediments to increasing the availability of counsel to the poor are vividly illustrated by the New York City Housing Courts. Reports that have examined the Housing Courts uniformly

341. As a matter of logic, the elimination of attorneys from the scene also would eliminate the ethical problem. But see supra text accompanying notes $325-329$.

342. See, e.g., Wilkins, supra note 15, at 812-14 (discussing limitations of lawyer self-regulation generally).

343. It is beyond the scope of this Article to discuss the range of features that could be included in a pro bono program, or the arguments for and against any such program. For an introduction to the subject, see GILlERs, supra note 9, at 182-87; HAZARD ET AL., supra note 9, at 1043-49; DAvid Luban, Lawyers and Justice: An EThical Study (1988); see also Debra Burke et al., Pro Bono Publico: Issues and Implications, 26 Loy. U. CHI. LJ. 61 (1994); Mary Coombs, Your Money or Your Life: A Modest Proposal for Mandatory Pro Bono Services, 3 B.U. PuB. INT. L.J. 215 \& n.1 (1993).

344. See Model Code of Professional Responsibility EC 1-1 (1980) ("A basic tenet of the professional responsibility of lawyers is that every person in our society should have ready access to independent professional services of a lawyer of integrity and competence."). 
called for the expansion of the availability of counsel and even a right to counsel in Housing Court. ${ }^{345}$ The call spread to bar committees examining the problems facing tenants in Housing Court. ${ }^{346}$ The plight of unrepresented tenants in Housing Court contributed to the Marrerro Commission's recommendation to then Chief Judge Sol Wachtler that a mandatory pro bono obligation should be imposed on all members of the bar. ${ }^{347}$ Housing advocates filed litigation seeking to establish a right to counsel for litigants in New York City's Housing Court. ${ }^{348}$

A variety of legal and policy arguments supported the call for increased counsel. From a legal standpoint, inequality of representation deprives tenants of their legal rights. ${ }^{349}$ Indeed, "[s]ince the presence or absence of counsel is known to play a major (if not dispositive) role in most evictions proceedings, parity of representation would obviously reduce significantly" the number of evictions. ${ }^{350}$ Though the legally

345. See, e.g., 5 MINUTE JUSTICE, supra note 105, at 92 (noting that the first recommended fundamental change that can remedy the inequity between represented landlords and unrepresented tenants is "guaranteed legal representation for those tenants who cannot afford counsel"); JUSTICE Evicted, supra note 119 , at 50 ("Appointed counsel should be provided to litigants faced with evictions who cannot afford to retain counsel."); STEMMING THE TIDE, supra note 132, at 62-66.

346. See Committee on Legal Assistance, Association of the Bar of the City of New York, Housing Court Pro Bono Project, Part I, at 36 (June 1988) [hereinafter Pro Bono Project Part 1] (unpublished manuscript) ("[P]rovision of counsel to persons facing eviction constitutes the single indispensable reform required in the Housing Court."); Committee on Legal Problems of the Homeless, Association of the Bar of the City of New York, Report of the Committee on Legal Problems of the Homeless 40 (1988) (unpublished manuscript) [hereinafter 1988 N.Y. Homeless Report] ("We therefore recommend a tenfold expansion in appropriations for the provision of counsel for families and individuals facing eviction."); Committee on Legal Assistance, Association of the Bar of the City of New York, Report on the Prevention of Homelessness by Providing Legal Representation to Tenants Faced with Eviction Proceedings (1987) (unpublished manuscript).

347. See Committee to Improve the Availability of Legal Services, Final Report to The Chief Judge of the State of New YoRk 18 (1990), reprinted in 19 Hofstra L. Rev. 755 (1991) ("[Olur society has evolved so that the poor need legal help to obtain basic human requirements and to an appalling degree cannot get it.") The report quoted Judge Wachtler's own charge to the Commission that "a justiee system which allows vast disparities in access to justice based on ability to pay cannot truly be called a system of justice at all." Id. at 20.

348. See Donaldson v. State, 548 N.Y.S.2d 676 (N.Y. App. Div. 1989). In addition to filing Donaldson, which was a class action, advocates also assisted pro se tenants in filing individual motions seeking appointment of counsel. See UBO Realty Corp. v. Fulton, No. 98761/91 (N.Y. Civ. Ct. Dec. 9, 1991); Gardenia Realty v. McMillan, No. 77216/87 (N.Y. Civ. Ct. Aug. 3, 1987); Eos Brook Ass'n v. Lizard, No. $77533 / 87$ (N.Y. Civ. Ct. July 1, 1987).

349. Pro Bono Project Part I, supra note 346, at 36-51. The legal arguments supporting the right to counsel litigation included federal due process claims, state due process claims, and claims arising from poor person's statutes. The analysis supporting the claims is set forth in Andrew Scherer, Gideon's Shelter: The Need to Recognize a Right to Counsel for Indigent Defendants in Eviction Proceedings, 23 HARv. C.R.-C.L. L. REv. 557, 562-87 (1988). Scherer notes, "By failing to recognize a right to counsel in most civil matters, the United States lags behind many developed western nations. A basie assumption of the legal systems of England, France, Switzerland and other European countries is that, for the poor to have meaningful access to the courts, they must have a right to representation by counsel." Id. at 560; see also HAZARD ET AL., supra note 9, at 1035-42.

350. 1988 N.Y. Homeless Report, supra note 346, at 36; see also STEMmiNG THE TIDE, supra note 132 , at $62-66$. 
correct result may have been one that favored the tenant, the tenant is deprived of that rightful claim, and the system fails to uphold its promise of just adjudication, because the tenant has no counsel. From an economic and social perspective, reducing eviction by providing counsel would dramatically reduce the incidence of homelessness, often the consequence of eviction. ${ }^{351}$ The costs saved in preventing homelessness would not only offset the cost of providing counsel, but would lead to substantial savings of public funds. ${ }^{352}$

Despite multiple calls for action by the profession, the vast majority of tenants remain without counsel. City- and state-funded programs supporting legal services have been cut back or eliminated. Federallyfunded legal services face calls for elimination and are being severely cut back and restricted. ${ }^{353}$ Income derived from Interest on Lawyers Trust Accounts (IOLTA) has diminished due to falling interest rates. ${ }^{354}$ The class action seeking to establish a right to counsel became mired in a procedural morass. ${ }^{355}$ The Marrero Commission's call for mandatory pro bono service has gone unheeded. Increasing numbers of families in New York City have fallen below the poverty line, increasing in turn the number of families in need of free legal services. ${ }^{356}$

As with the attorney behavior examined in Part II, the trends in New York City's Housing Court may be more pronounced than in other courts, but they are not unique to that setting. The presence of counsel has a dramatic effect on the outcome of legal proceedings. ${ }^{357}$ The calls

351. See, e.g., 144 Woodruff Corp. v. Lacrete, 585 N.Y.S.2d 956, 960 (N.Y. Civ. Ct. 1992); 1988 N.Y. Homeless Report, supra note 346, at 34; CommitTeE on Legal AssistanCE, Association of The Bar of The City of New York, Report on the Prevention of Homelessness by Providing Legal Representation to Tenants Faced with Eviction Proceedings 6 (1987) [hereinafter 1987 N.Y. HOMELESS REPORT].

352. See Housing Court, Evictions AND Homelessness, supra note 111, at iv ("Establishing a right to counsel for tenants in Housing Court would save approximately $\$ 67$ million in annual shelter costs and spare thousands of families the hardship of life on the street or in shelters, and the frustration of trying to find safe, low cost apartinents in a city where precious few still exist."); see also id. at 14-19; STEMming THE TIDE, supra note 132, at 64; 1987 N.Y. HoMELESS REPORT, supra note 351 , at 33-40.

353. See, e.g., Congress' Republican Majority Targeted Legal Aid and Finally Won Big Cutbacks, NAT'L L.J., Dec. 25, 1995/Jan. 1, 1996, at C12.

354. See, e.g., Housing Court, Evictions AND Homelessness, supra note 111, at 16 n.33 (noting "declining revenues from the lnterest on Lawyers Accounts Program," New York's version of 1OLTA).

355. See Donaldson v. State, 548 N.Y.S.2d 676 (N.Y. App. Div. 1989).

356. See, e.g., Housing Court, Evictions AND Homelessness, supra note 111, at 2 ("The summer of 1992 was punctuated by the news that the number of public assistance recipients, primarily 'unskilled workers who have had trouble competing for jobs in the recession ..., ', rose by 22\% since 1990.") (quoting Celia W. Dugger, Welfare Rolls Hit the Million Mark in New York City: Highest Total Since 70's, N.Y. Times, Aug. 12, 1992, at 1).

357. See, e.g., Engler \& Bloomgarden, supra note 163, at 5, 64; Fusco et al., supra note 171, at 114; Marilyn Miller Mosier \& Richard A. Soble, Modern Legislation, Metropolitan Court, Miniscule 
for provision of counsel, and even a right to counsel, liave resounded in courts beyond New York City. ${ }^{358}$ Yet, the legal needs of the poor remain largely unmet across the country. ${ }^{359}$ The dramatic increase in the number of Americans living in poverty has been a nationwide trend. ${ }^{360}$ The legal services cutbacks and restrictions are nationwide. ${ }^{361}$ The drop in interest rates affected IOLTA funding for legal services well beyond New York City, ${ }^{362}$ and IOLTA programs are facing challenges to their constitutionality. ${ }^{363}$ No state has adopted a mandatory pro bono program, and, according to some reports, efforts to implement such a program are dead. ${ }^{364}$

Results: A Study of Detroit's Landlord-Tenant Court, 7 U. Mich. JL. REFORM 8, $35-37$ (1973); Rulli, supra note 1, at 547-51.

358. See, e.g., Quail v. Municipal Court, 217 Cal. Rptr. 361 (Cal. Ct. App. 1985); Payne v. Superior Court, 553 P.2d 565 (Cal. 1976); Genninger v. Genninger, 640 N.E.2d 472, 474 (Mass. 1994) (seeking appointment of counsel in a property division case: "an indigent litigant is not constitutionally entitled to a court-appointed attorney in every civil case."); In re Smiley, 330 N.E.2d 53 (N.Y. App. Div. 1975) (seeking appointment of counsel in divorce actions); see also Lassiter v. Department of Soc. Servs., 452 U.S. 18, 32-33 (1981).

Sterling \& Schrag propose a related solution to the problem of the high default rate in the consumer context. Under one version of their proposal, "a publicly paid official would attempt to contact, educate, and offer to speak for consumer defendants." Sterling \& Schrag, supra note 173, at 387. The official would help the defendant in various aspects of the case, "and, of course, by representing the defendant in any negotiation with the creditor." Id. at 388; see also Rulli, supra note 1 , at 551-52.

The arguments supporting a right to counsel in New York would be identical or analogous in other jurisdictions. See generally Scherer, supra note 349.

359. See supra note 1 and accompanying text.

360. See, e.g., Bureau of THE Census, U.S. Dep't of Commerce, Statistical Abstract OF THE UNITED STATES 480 (1995) (reporting that the number of Americans living in poverty exceeded 39 million in 1993 and that the poverty rate rose from $13 \%$ to $15.1 \%$ between 1980 and 1993); Randolph E. Schmid, Poverty Found to Be on Rise Despite Upturn, Boston GLoBE, Oct. 7, 1994, at 3 (noting highest poverty rate since 1961); see also Rulli, supra note 1, at 552 n.62 ("The problem [of unmet legal needs] has worsened as the national population of people in poverty has increased from 26 million in 1979 to 39.3 million in I994. Today, there is one lawyer for every 305 Americans, but there is only one legal services lawyer for every 10,567 poor Americans.") (citation omitted).

361. See, e.g., Rulli, supra note 1, at 553-55.

362. See, e.g., GBLS 1994 ANNUAL REPORT, supra note 164, at 3 ("[W] ith no increase in federal or state funds and the continued decline in 1OLTA revenues, GBLS has been forced to reduce its staff by twenty-five positions since 1993.").

363. The Fifth Circuit has found Texas' mandatory IOLTA program to be unconstitutional. Washington Legal Found. v. Texas Equal Access to Justice Found., 94 F.3d 996 (5th Cir. 1996). The First and Eleventh Circuits have upheld the validity of IOLTA statutes in the face of similar challenges. Washington Legal Found. v. Massachusetts Bar Found., 993 F.2d 962 (1st Cir. 1993); Cone v. State Bar, 819 F.2d 1002 (11th Cir. 1987).

364. See Bill 1belle, Mandatory Movement Dies as Pro Bono Hours Rise, LAw. WkLY. USA, May 22, 1995, at 14.

There were strong mandatory movements in Texas, New York and Nevada in the late 1980s and early 1990s, but each dissipated when state bar associations mounted aggressive efforts to boost voluntary pro bono work by lawyers. Other states exploring mandatory pro bono also backed off as lawyers increased their donated services. 
Logic suggests that the provision of counsel is the only real solution to the problems identified in this Article. Reality suggests that the solution may be illusory. Even staunch supporters of an increase of lawyers for the poor have recognized that "there will necessarily be a permanent condition of scarcity in the availability of lawyers." ${ }^{365}$ The increased provision of counsel may comprise only a partial response, but it must remain high on the list of possible responses and be advocated along with other responses. ${ }^{366}$

Recognition of attorney misconduct during negotiations with unrepresented adversaries must lead the profession to redouble its efforts to provide connsel, at least to litigants in particular civil contexts, as a component of its overall enforcement strategy. Whatever inroads can be made toward providing counsel for the poor in civil cases will carry with them the amelioration of the ethical problems discussed above.

\section{CONCLUSION}

The problem of attorney misconduct in negotiations with unrepresented parties is intertwined with problems reaching well beyond the legal system. These problems in turn are rooted in poverty, and comprise only a fraction of the innumerable issues facing the poor. Since they disproportionately affect women and members of racial and ethnic minorities, the problems likely are rooted in issues of bias and disparate treatment as well. It is hardly surprising that possible responses to the problems, even if implemented, should not be expected to constitute complete solutions. True solutions are intertwined with solutions to the more general problems facing the poor, women, and racial and ethnic minorities.

Although complete solutions may lie outside the legal system, it does not follow that the legal profession is relieved of the obligation to take corrective steps. The problems are ones of legal ethics. They involve behavior by attorneys that violates the rules established by

Id. Notwithstanding the reported increase in voluntary pro bono efforts, those efforts apparently have failed to make significant inroads on the representation rates in the "poor people's courts."

365. Bellow \& Kettleson, supra note 102, at 380. As Professors Bellow and Kettleson explain, legal needs are not static, and tend to expand as potential beneficiaries see lawyers as capable of responding to their problems. Even if demands were constant, "it would not be possible or desirable to expand the bar to meet the need. ... It would require something on the order of a tenfold increase in the size of the entire bar to begin to provide the whole population with the same legal services that the affiuent presently enjoy." Id. Some litigants, moreover, choose to appear pro se even if counsel is available. Bellow and Kettleson do not address the reasons for such a choice. But see Sales et al., supra note 200.

366. While resolving the ethical problem, an increase in counsel might produce a backlash in some settings. For example, as Lazerson relates, successes by lawyers for tenants in the Bronx were followed by procedural changes that undercut the effectiveness of some of the lawyers' tactics. See Lazerson, supra note 308; Simon, supra note 323 (analyzing Lazerson's article). 
attorneys to regulate attorneys. The ethical problems occur in the context of legal proceedings and affect the legal rights of litigants. The legal proceedings likely occur under the auspices of judges, whose behavior is regulated in their capacities both as judges and lawyers.

As set forth in this Article, a number of corrective steps are available to the profession. Given the scope of the problem, and the difficulties likely to arise with each corrective step, the legal profession's overall enforcement strategy must employ a range of options. States should increase enforcement of violations of DR 7-104(A)(2) and Rule 4.3 in the context of negotiations between lawyers and unrepresented litigants. States should adopt additional disciplinary rules that will protect unrepreseuted parties forced to negotiate against lawyers. Courts must provide additional oversight to ensure that the rights of unrepresented litigants are protected. Finally, the profession must redouble its efforts to expand the provision of counsel in civil proceedings in which lawyers oppose unrepresented parties.

The need for the legal profession to address its own ethical problems, however broadly rooted, goes to the very integrity of the profession's system of self-government. ${ }^{367}$ The willingness of the profession to struggle for solutions should flow from the aspirational goals of the profession as well. "A lawyer should assist in improving the legal system." 368

[L]awyers are especially qualified to recognize deficiencies in the legal system and to initiate corrective measures therein. Thus they should participate in proposing and supporting legislation and programs to improve the system, without regard to the general interests or desires of clients or former clients. ${ }^{369}$

An unwillingness or inability on the part of the profession to address ethical problems arising in lawyers' negotiations with the poor would send a powerful and unfortunate message about the efficacy of the rules themselves. It would reveal an inability on the part of the legal profession to regulate itself in a manner that identifies and eliminates attorney misconduct. It would also perpetuate the subordination and silencing of those who are often powerless in our legal system and our society.

367. See Model Rules of Professional Conduct Preamble (1983) (emphasis added):

The legal profession's relative autonomy carries with it special responsibilities of selfgovernment. The profession has a responsibility to assure that its regulations are conceived in the public interest and not in furtherance of parochial or self-interested concerns of the bar. Every lawyer is responsible for observance of the Rules of Professional Conduct. A lawyer should also aid in securing their observance by other lawyers. Neglect of these responsibilities compromises the independence of the profession and the public interest which it serves.

368. Model Code of Professional Responsibility Canon 8 (1981).

369. Model Code of Professional Responsibility EC 8-1 (1981) (footnotes omitted). 